\title{
ipen
}

AUTARQUIA ASSOCIADA À UNIVERSIDADE DE SÃO PAULO

\section{ESTUDOS DE DURABILIDADE DE CONJUNTOS ELETRODO-MEMBRANA- ELETRODO (MEAs) PRODUZIDOS POR IMPRESSÃO À TELA PARA USO EM CÉLULAS A COMBUSTÍVEL DO TIPO PEM}

\section{VINÍCIUS ANDREA}

Dissertação apresentada como parte dos requisitos para obtenção do Grau de Mestre em Ciências na Área de Tecnologia Nuclear Materiais

Orientador:

Prof. Dr. Marcelo Linardi 
Dedico este trabalho à ciência por esta tornar a vida mais aprazível a cada passo que dá. 


\section{AGRADECIMENTOS}

Agradeço à minha família por todo o amor, dedicação e paciência, e em especial a minha mulher, amiga, companheira e amor da minha vida, Lara.

Meus sinceros agradecimentos ao Dr. Marcelo Linardi pela orientação, oportunidade, amizade e confiança em mim depositada.

Devo muita gratidão também à Patrícia da S. Pagetti de Oliveira, pelas orientações, sugestões, correções e amizade.

Ademais, agradeço imensamente aos colegas, funcionários e pesquisadores do $\mathrm{CCCH} / \mathrm{IPEN}$ pelo companheirismo, aprendizado e, acima de tudo, amizade conquistada. 


\title{
ESTUDOS DE DURABILIDADE DE CONJUNTOS ELETRODO-MEMBRANA- ELETRODO (MEAs) PRODUZIDOS POR IMPRESSÃO À TELA PARA USO EM CÉLULAS A COMBUSTÍVEL DO TIPO PEM
}

\author{
Vinícius Andrea
}

\section{RESUMO}

Custo e durabilidade ainda são os maiores impeditivos para a entrada das células a combustível no mercado de dispositivos usados para produção de eletricidade. Assim, o objetivo deste trabalho foi avaliar a durabilidade dos conjuntos eletrodo-membranaeletrodo (MEAs) produzidos no IPEN pelo método de impressão à tela para uso em células a combustível do tipo PEM. Para tanto, foi necessário desenvolver um protocolo adequado de teste de durabilidade de longa duração, visando obter estimativas da taxa de queda do potencial elétrico da célula a combustível ao longo do tempo e, assim, fazer inferência a respeito do tempo de vida deste dispositivo. Os MEAs testados durante este estudo foram preparados pelo método de impressão à tela com catalisador de $\mathrm{Pt} / \mathrm{C}$ comercial e membrana Nafion ${ }^{\circledR} 115$. O aprimoramento do protocolo de teste de durabilidade de longa duração se deu pela escolha dos procedimentos a serem executados e pelo ajuste de alguns parâmetros de operação da célula a combustível, tais como temperatura da célula, fluxo de $\mathrm{H}_{2}$ e fluxo de $\mathrm{O}_{2}$. Para a análise dos dados obtidos com os testes, foram aplicados métodos estatísticos de ajuste de modelos e curvas de polarização. Além disso, amostras da camada catalítica de um dos MEAs utilizados nos testes de durabilidade de longa duração foram analisadas por meio de microscopia eletrônica de transmissão (MET) para serem comparadas com amostras da camada catalítica de um MEA de controle. Para se avaliar o desempenho global da célula a combustível do tipo PEM em operações de longa duração, um dos grandes desafios foi fazer a separação entre as componentes de perda de desempenho que são reversíveis das irreversíveis. As estimativas obtidas para a taxa de queda do potencial elétrico da célula a combustível ao longo do tempo variaram num intervalo de 108,19 a $318,15 \mu \mathrm{V} \cdot \mathrm{h}^{-1}$. Estes resultados podem ser considerados satisfatórios quando comparados com valores apresentados na literatura. Finalmente, as imagens obtidas por MET mostraram uma tendência de aumento no tamanho médio das partículas Pt em decorrência do tempo de operação dos MEAs, mas que não implicou numa queda significativa do desempenho das células a combustível do tipo PEM testadas. 


\title{
DURABILITY STUDIES OF MEMBRANE ELECTRODE ASSEMBLIES (MEAs), PRODUCED THROUGH TH SIEVE PRINTING TECHNIQUE FOR USE IN PROTON EXCHANGE MEMBRANE FUEL CELLS
}

\author{
Vinícius Andrea
}

\begin{abstract}
Cost and durability still represent the major barriers to the entry of proton exchange membrane fuel cells (PEMFCs) in the market. Thus, the objective of this work was to assess the durability of membrane-electrode assemblies (MEAs) produced at IPEN through the sieve printing method to be used in PEMFCs. For this purpose, an adequate long-term test protocol was developed aiming to obtain estimates of the voltage decay rate and lifetime of the PEMFCs. In the preparation of the MEAs through the sieve printing method commercial Pt/C catalyst and Nafion ${ }^{\circledR} 115$ membranes were used. In the development of the long-term test protocol some procedures were defined and the fuel cell operational parameters were adjusted, such as cell temperature, $\mathrm{H}_{2}$ and $\mathrm{O}_{2}$ flows. In the analysis of the data obtained from the tests, statistical methods and polarization curves were applied. Samples of the catalyst layer from a MEA used in a long-term test were compared with samples from a control MEA using a Transmission Electron Microscopy (TEM). To evaluate the overall performance of the PEMFCs in long-term operations, a major challenge was to make the separation between the components of performance loss that are reversible from the ones that are irreversible. The estimates for the voltage decay rate ranged from 110 to $318 \mu \mathrm{V} \cdot \mathrm{h}^{-1}$. These results can be taken as satisfactory when compared with values reported in the literature. Finally, there was an increase in the average size of Pt particles in the catalyst of the long-term tested MEA, as observed in the micrographs. However, this increase did not lead to a significant performance loss of the PEMFCs.
\end{abstract}




\section{SUMÁRIO}

1 INTRODUÇÃO . .9

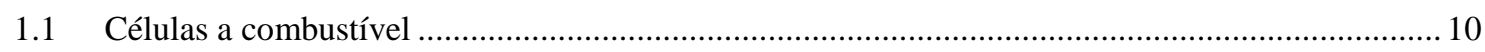

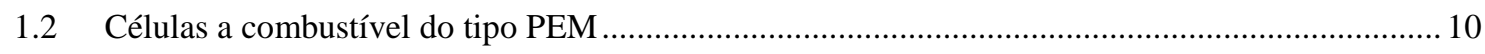

1.3 Métodos de produção de conjuntos eletrodo-membrana-eletrodo (MEAs) para células a

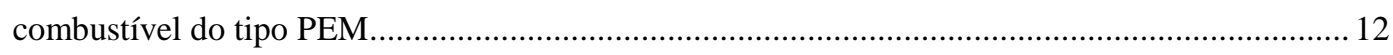

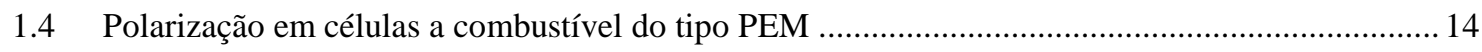

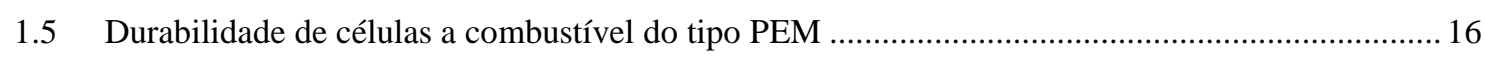

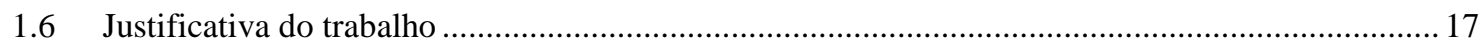

2 OBJETIVOS

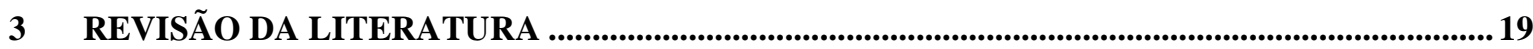

3.1 Métodos de análise da durabilidade de células a combustível do tipo PEM.................................... 19

3.2 Mecanismos de degradação da camada catalítica do eletrodo de difusão gasosa da célula a

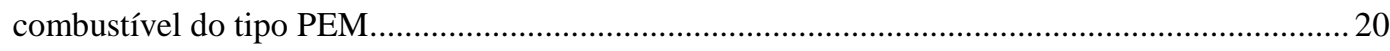

3.3 Mecanismos de degradação da membrana polimérica da célula a combustível do tipo PEM .........21

3.4 Mecanismos de degradação das placas monopolares das células a combustível do tipo PEM ........22

3.5 Considerações gerais sobre fatores que afetam a durabilidade de células a combustível do tipo PEM..

4 METODOLOGIA

4.1 PARTE I - Métodos usados na produção dos conjuntos eletrodo-membrana-eletrodo, montagem das células a combustível do tipo PEM e desenvolvimento dos testes de durabilidade .25

4.1.1 Produção dos conjuntos eletrodo-membrana-eletrodo (MEAs) para células a combustível do tipo PEM .25

4.1.1.1 Tratamento químico da membrana condutora de prótons ...................................................... 25

4.1.1.2 Produção dos Eletrodos de Difusão Gasosa (EDGs) ........................................................ 26

4.1.1.2.1 Preparo da Tinta Precursora da Camada Catalítica (TPCC) ........................................... 26

4.1.1.2.2 Aplicação da TPCC por meio da técnica de impressão à tela .......................................2 27

4.1.1.3 Prensagem dos conjuntos eletrodo-membrana-eletrodo (MEAs) ..................................... 28

4.1.1.4 Montagem dos conjuntos eletrodo-membrana-eletrodo (MEAs) nas células a combustível

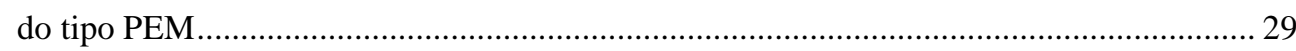

4.1.2 Recursos laboratoriais e montagem dos testes com as células a combustível do tipo PEM ......29

4.1.3 Protocolos de teste de durabilidade de longa duração com células a combustível do tipo PEM

4.2 PARTE II - Métodos usados para análise dos resultados obtidos nos testes de durabilidade das células a combustível do tipo PEM. 
4.2.1 Análise do potencial elétrico da célula a combustível em função da densidade de corrente elétrica: curvas de polarização.

4.2.2 Análise estatística da variação do potencial elétrico da célula a combustível em função do tempo.

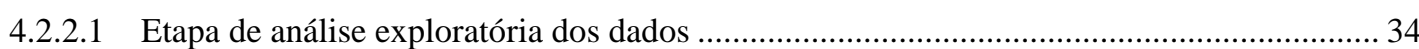

4.2.2.2 Etapa de ajuste de um modelo estatístico aos dados observados ................................... 35

4.2.3 Análise das características morfológicas do catalisador usado nos conjuntos eletrodomembrana-eletrodo (MEAs) após os testes de durabilidade de longa duração - caracterização por Microscopia Eletrônica de Transmissão (MET)

5.1 Resultados dos testes de durabilidade de longa duração com as células a combustível do tipo PEM.

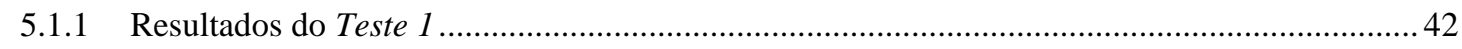

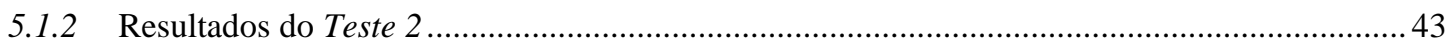

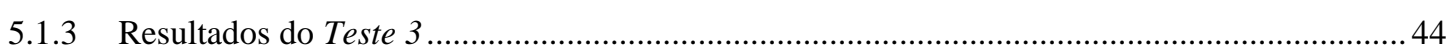

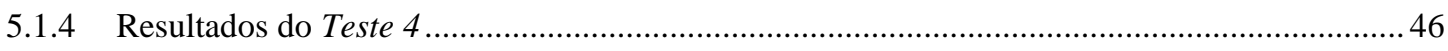

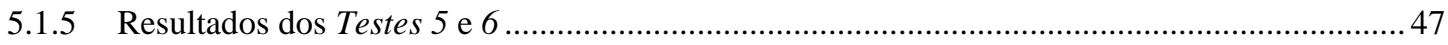

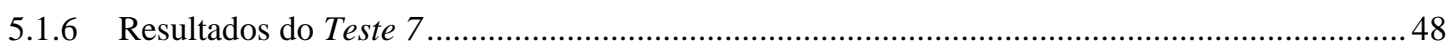

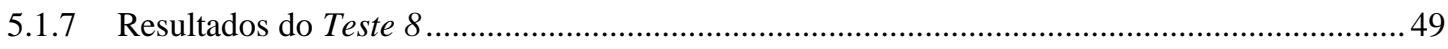

5.2 Análise dos resultados obtidos nos testes de durabilidade de longa duração com as células a combustível do tipo PEM produzidas no IPEN .................................................................... 51

5.3 Caracterização dos MEAs por Microscopia Eletrônica de Transmissão (MET) ...........................56

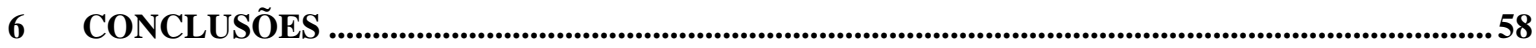

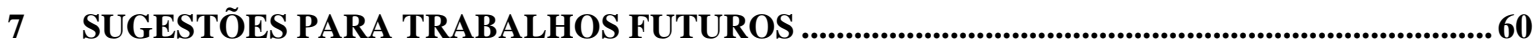

ANEXO A - DIAGRAMA DE BLOCOS DO PROTOCOLO IMPLEMENTADO .................................62

ANEXO B - ROTINA UTILIZADA NOS TESTES 1, 2, 5, 6, 7 e 8..............................................63

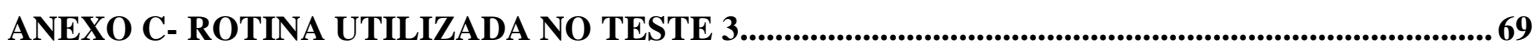

ANEXO D - ROTINA UTILIZADA NO TESTE 4............................................................................... 76

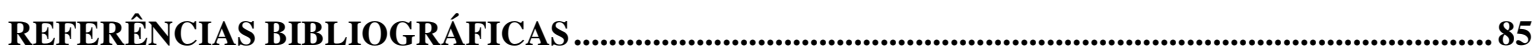




\section{LISTA DE ABREVIATURAS OU SIGLAS}

ANOVA - ANalysis Of VAriance - Análise de Variância

EDG - Eletrodo de Difusão Gasosa

ICB - $\quad$ Instituto de Ciências Biomédicas

IPEN - Instituto de Pesquisas Energéticas e Nucleares

MEA - Membrane Electrode Assembly - Conjunto Eletrodo-Membrana-Eletrodo

MET - Microscopia Eletrônica de Transmissão

PEM - $\quad$ Proton Exchange Membrane - Membrana Trocadora de Prótons

RHE - Reference Hydrogen Electrode - Eletrodo de Referência de Hidrogênio

ROH - Reação de Oxidação do Hidrogênio

RRO - Reação de Redução do Oxigênio

TD - $\quad$ Teste de Durabilidade

TDLD - $\quad$ Teste de Durabilidade de Longa Duração

TEA - $\quad$ Teste de Estresse Acelerado

TPCC - Tinta Precursora da Camada Catalítica

USP - $\quad$ Universidade de São Paulo 


\section{INTRODUÇÃO}

A energia desempenha um papel fundamental no desenvolvimento humano, principalmente por suprir necessidades essenciais para a sobrevivência das pessoas. Portanto, não é de se surpreender que a produção e o consumo energético sejam algumas das atividades mais importantes da humanidade. De fato, argumenta-se que a energia é a chave para a evolução das civilizações, e que esta evolução está fortemente relacionada ao modo com que a conversão energética é realizada para satisfazer as necessidades do ser humano [1].

Com a crescente demanda por energia ao longo dos tempos, as civilizações se tornaram altamente dependentes de fontes energéticas não renováveis, as quais têm apresentado tecnologias consolidadas. No entanto, o uso destas fontes leva a consequências nocivas ao meio ambiente, tais como destruição de ecossistemas, deterioração da camada de ozônio, aumento dos gases de efeito estufa, doenças, além de outras [2]. Assim sendo, a busca por novas fontes de energia, capazes de substituírem as que governam a economia atual e que garantam a sustentabilidade energética do futuro, sendo economicamente viáveis, mais limpas e mais eficientes do que aquelas dos dias de hoje é, sem sombra de dúvidas, um dos grandes desafios do século 21. Neste contexto, as células a combustível estão entre as tecnologias mais promissoras, visto que estes dispositivos podem produzir energia elétrica com baixa emissão de poluentes e de forma muito eficiente [3,4].

A invenção das células a combustível ocorreu há mais de 100 anos. Por terem custo muito elevado, sua aplicação prática se deu somente na década de 60, no programa espacial norte-americano. Com o grande desenvolvimento na área de materiais dos últimos anos, esta tecnologia, associada à crescente exigência de baixo impacto ambiental, tornou-se bastante promissora no cenário mundial de energia. As células a combustível representam, já em médio prazo, uma alternativa, tanto para motores a combustão interna (unidades móveis), como para geradores de energia de pequeno e médio portes $(100 \mathrm{~kW})$ até plantas da ordem de MW de potência (unidades estacionárias), além de aplicações portáteis [4,5]. 


\subsection{Células a combustível}

As células a combustível são dispositivos eletroquímicos capazes de converter a maior parte da energia química de um combustível diretamente em energia elétrica de forma limpa e eficiente. Numa célula a combustível, as reações de oxidação e redução ocorrem em eletrodos distintos - ânodo e cátodo, respectivamente - e são separadas por um eletrólito apropriado, sendo que com o uso do hidrogênio como combustível e do oxigênio como oxidante tem-se apenas a formação de água e calor como produtos das reações (1), (2) e (3). Esta é a condição ideal, do ponto de vista ecológico, para o uso das células a combustível $[3,4]$.

$$
\begin{array}{ll}
\text { Ânodo: } & \mathrm{H}_{2}+2 \mathrm{H}_{2} \mathrm{O} \rightarrow 2 \mathrm{H}_{3} \mathrm{O}^{+}+2 \mathrm{e}^{-} \\
\text {Cátodo: } & 1 / 2 \mathrm{O}_{2}+2 \mathrm{H}_{3} \mathrm{O}^{+}+2 \mathrm{e}^{-} \rightarrow 3 \mathrm{H}_{2} \mathrm{O} \\
& -\mathrm{H}_{2}+1 / 2 \mathrm{O}_{2} \rightarrow \mathrm{H}_{2} \mathrm{O} \quad\left(\mathrm{E}^{0}=1,23 \mathrm{~V} \text { vs RHE }\right)
\end{array}
$$

Ao contrário dos motores a combustão interna, cuja eficiência teórica máxima é limitada pelo ciclo de Carnot, as células a combustível têm como vantagem inerente a elevada eficiência teórica ( $\eta_{\text {eletroquimica }}$ ) determinada pelo quociente entre a energia livre de reação $\left(\Delta G_{r}\right)$ e a entalpia da reação $\left(\Delta H_{r}\right)$, segundo a equação (4) [4]:

$$
\eta_{\text {eletroquimica }}=\frac{\Delta G_{r}}{\Delta H_{r}}
$$

São vários os tipos de células a combustível, os quais são classificados de acordo com o eletrólito utilizado e a temperatura de operação destes dispositivos eletroquímicos.

\subsection{Células a combustível do tipo PEM}

As células a combustível cujo eletrólito é uma membrana polimérica condutora de prótons, ou seja, as do tipo PEM (do inglês, Proton Exchange Membrane) estão entre as mais usadas tanto para aplicações estacionárias, quanto para aplicações móveis $[3,4]$.

São células de baixa temperatura de operação (entre 60 a $90^{\circ} \mathrm{C}$ ) e por serem robustas e de fácil operação, são as mais promissoras como alternativa para motores a combustão interna, além de possuírem vantagens inerentes como alta eficiência e baixa emissão de poluentes [3-6]. 
O funcionamento básico de uma célula a combustível do tipo PEM ocorre da seguinte maneira: no ânodo injeta-se hidrogênio e no cátodo, oxigênio. Os prótons gerados na reação anódica são conduzidos através da membrana eletrólito até o cátodo, onde se ligam ao oxigênio formando calor e água. Concomitantemente, os elétrons liberados na reação de oxidação percorrem um circuito externo até o cátodo, produzindo, assim, trabalho elétrico e calor. Todas estas reações são aceleradas por um catalisador. No atual estado da arte, a platina $(\mathrm{Pt})$ é o principal metal nobre utilizado para catalisar estas reações, visto que apresenta o melhor resultado. Devido ao alto valor e escassez desse metal, aplicase a Pt na forma de nanopartículas ancoradas em um carbono suporte condutor, no intuito de se maximizar a relação massa/superfície ativa [4]. Na Figura 1 é ilustrado o funcionamento básico de uma célula a combustível do tipo PEM.

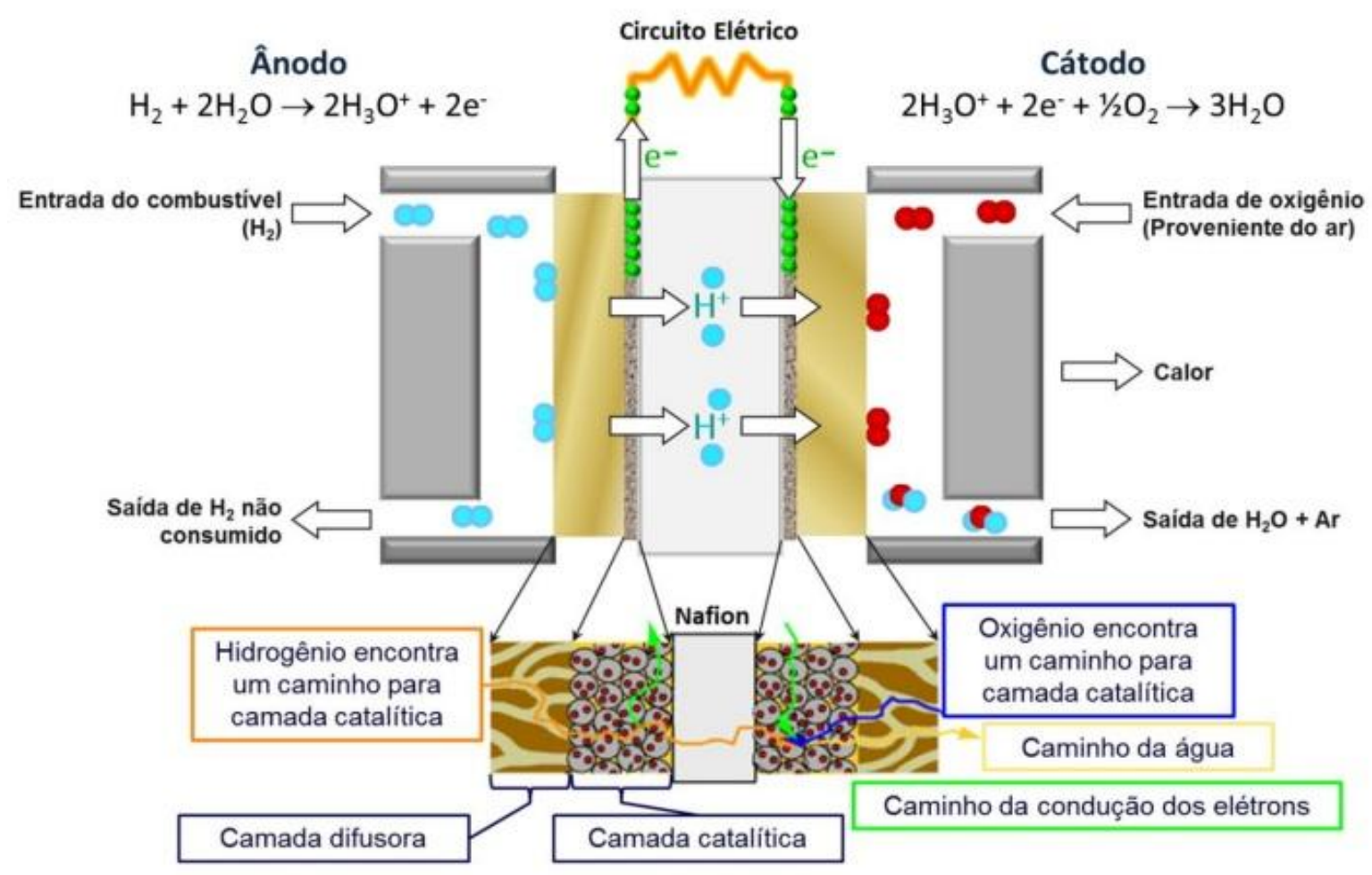

Figura 1 - Esquema ilustrativo do funcionamento de uma célula a combustível do tipo PEM [7].

Estruturalmente, as células a combustível do tipo PEM são constituídas de dois eletrodos de difusão gasosa (condutores eletrônicos) que são separados por um eletrólito sólido (membrana condutora de prótons), placas de grafite e juntas de vedação. O Eletrodo de Difusão Gasosa (EDG) é uma estrutura porosa, coerente e condutora de elétrons do sistema eletrodo / catalisador. O EDG é composto de duas camadas: a camada catalítica, onde se encontra disperso o catalisador, e a camada difusora. A construção da camada 
catalítica tem como função a maximização da interface trifásica gás-líquido-sólido, aumentando consideravelmente a velocidade dos processos eletródicos. Já a camada difusora tem como função otimizar a difusão dos gases até a camada catalítica. A membrana usada como eletrólito é composta de um polímero condutor protônico sólido que, quando hidratado, conduz íons do tipo $\mathrm{H}_{3} \mathrm{O}^{+}$. O conjunto Eletrodo-MembranaEletrodo é chamado de MEA (do inglês, Membrane Electrode Assembly) [3-6]. Na Figura 2 é apresentado o conjunto dos componentes essenciais de uma célula a combustível do tipo PEM.

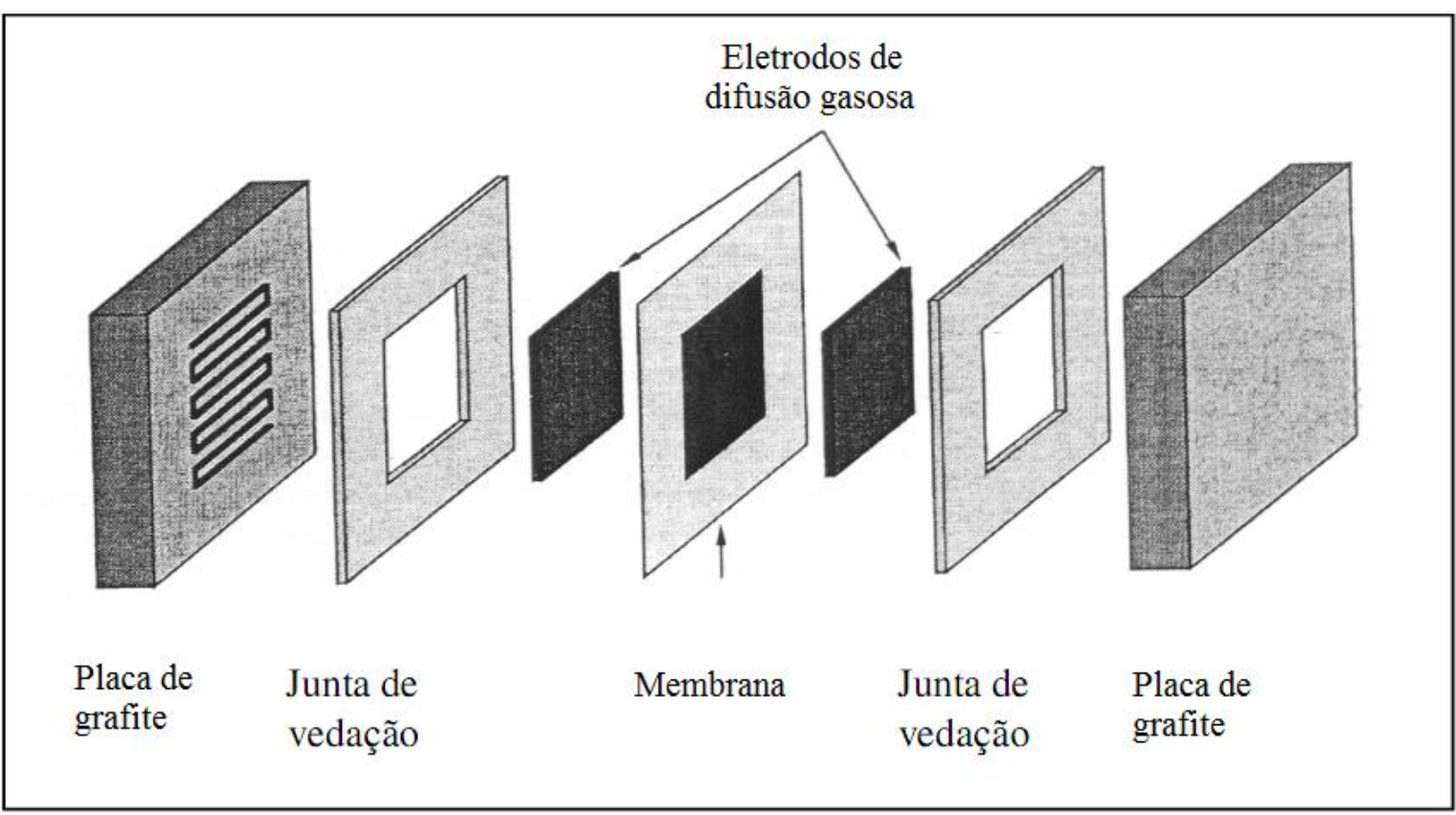

Figura 2 - Componentes essenciais de uma célula a combustível do tipo PEM. Adaptado de [8].

\subsection{Métodos de produção de conjuntos eletrodo-membrana-eletrodo (MEAs) para células a combustível do tipo PEM}

Os MEAs podem ser preparados de diversas formas e com vários tipos de materiais. Os eletrodos devem ser condutores elétricos e podem ser feitos de malha de titânio (Ti) ou de tecido / papel de carbono (C). Já os catalisadores podem ser aplicados diretamente sobre os eletrodos ou sobre a membrana eletrolítica, conforme apresentado na Figura 3. 
PROCESSOS DE PREPARAÇÃO DE MEAs

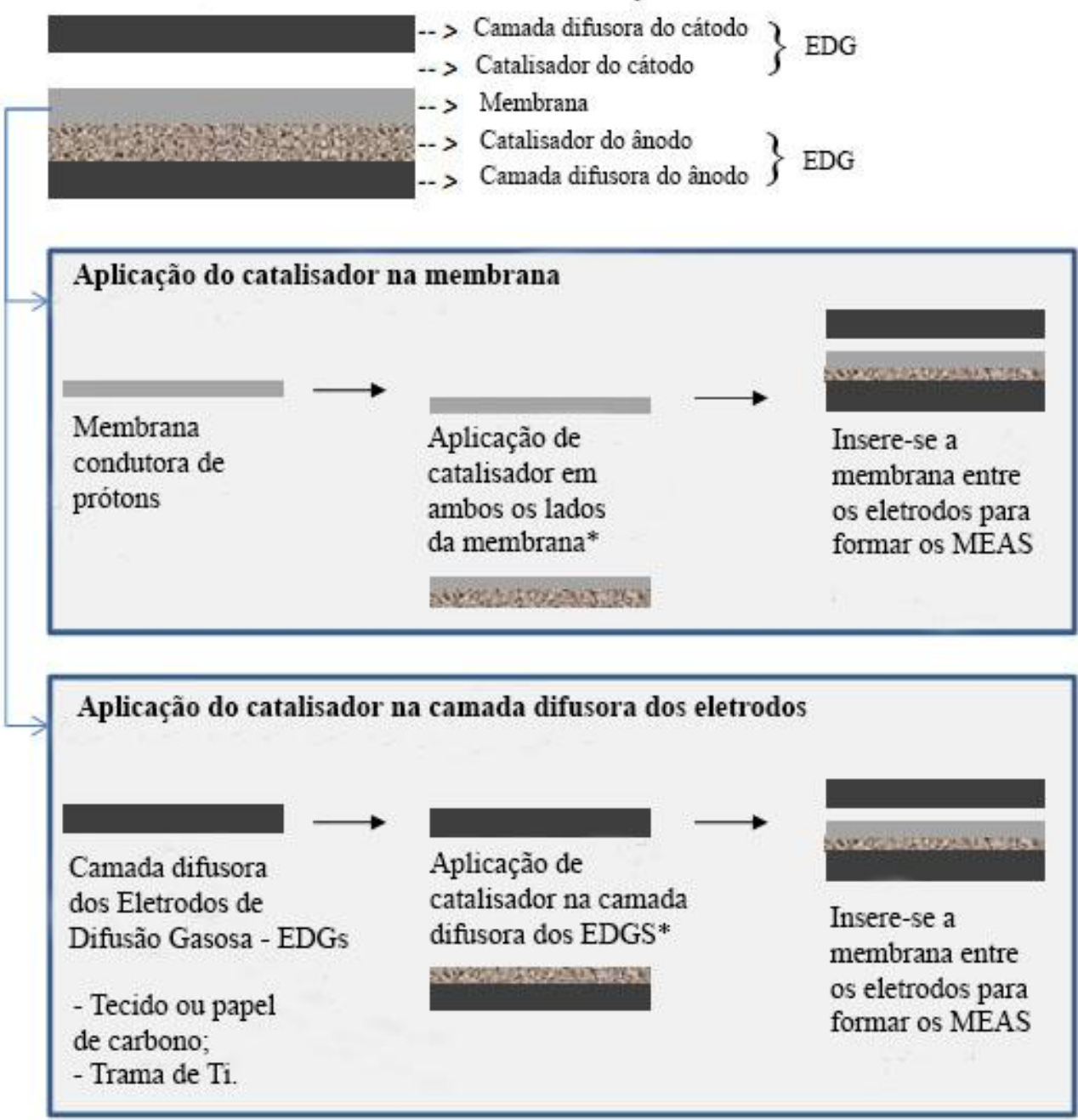

Figura 3 - Processos de preparação de MEAs. Adaptado de [9].

*As principais técnicas de aplicação de catalisador são:

- Spray à seco: esta técnica consiste em aplicar no substrato (membrana ou eletrodo) uma mistura seca de catalisador e Nafion ${ }^{\circledR}$ em pó por meio de um fluxo de nitrogênio através de bocais. Após a aplicação, o substrato é passado por uma calandra para uma melhor fixação do catalisador. O MEA é prensado à quente para melhorar o contato e a tripla fase reacional. Este processo é simples e, por ser realizado a seco, evita o uso de solventes. No entanto, o processo deve ser executado com precisão para que a distribuição de partículas seja uniforme [9];

- Espalhamento de pasta: consiste em espalhar uma emulsão previamente preparada contendo catalisador, solução de Nafion ${ }^{\circledR}$ e solventes sobre o substrato, usando para isso dois cilindros rotatórios. A espessura da camada catalítica é controlada ajustando-se a distância entre os dois cilindros. As camadas catalíticas geradas neste processo são uniformemente finas e a carga de catalisador aplicada é 
diretamente proporcional à espessura da camada. O MEA é preparado por prensagem à quente. Embora a produção de MEA por meio desta técnica seja altamente rápida e de fácil reprodução, o custo dos equipamentos e a demanda de produção são bem altos [9];

- Pintura à pincel: neste método, prepara-se uma tinta contendo catalisador, solução de Nafion ${ }^{\circledR}$ e solventes, e esta tinta é aplicada com um pincel diretamente sobre o eletrodo ou membrana. Embora este processo seja lento e requer a preparação da tinta com a quantidade exata de carga de catalisador que se deseja aplicar, esta técnica é bastante útil para laboratório, onde a escala de produção não é um fator importante [9];

- Impressão à tela: esta técnica consiste em se pressionar uma tinta contendo catalisador, solução de Nafion $^{\circledR}$ e solventes através de uma tela ou malha para uma superfície abaixo. Assim, esta tinta atravessa uma determinada área da tela (por meio de um rodo que é deslizado fazendo pressão sobre a tela) e se fixa no substrato, que pode ser a membrana ou o eletrodo. O MEA é, então, montado por meio da prensagem à quente de seus componentes. Esta técnica, que foi aplicada para a produção dos MEAs utilizados neste trabalho, possui algumas vantagens sobre as outras, tais como a rapidez associada à excelente reprodutibilidade da morfologia e, consequentemente, do desempenho do eletrodo e do MEA [9].

\subsection{Polarização em células a combustível do tipo PEM}

Com a injeção contínua dos gases reagentes em uma célula a combustível do tipo PEM, cria-se uma diferença de potencial entre os dois eletrodos e, consequentemente, uma força eletromotriz que pode gerar correntes elétricas. No entanto, com o escoamento das cargas elétricas, surgem também perdas de potencial da célula a combustível, em decorrência de barreiras energéticas a serem rompidas para que as reações eletroquímicas ocorram. Se, por algum processo, o potencial do eletrodo da célula a combustível se afasta do potencial de equilíbrio, diz-se que o eletrodo sofreu polarização. A medida da polarização é chamada de sobrepotencial. Numa célula a combustível do tipo PEM ocorrem três formas de polarização, que são: polarização por ativação, por queda ôhmica e por difusão [4,5]. 
A polarização por ativação é ocasionada pela reorganização dos íons, reorientação dos dipolos do solvente, penetração dos íons solvatados nas diversas camadas do eletrodo e pela transferência dos elétrons da superfície do catalisador. É assim chamada por estar relacionada à cinética das reações que ocorrem nos eletrodos. Numa célula a combustível do tipo PEM, as perdas por ativação no ânodo podem ser consideradas desprezíveis, pois a Reação de Oxidação do Hidrogênio $(\mathrm{ROH})$ no ânodo é muito mais rápida que a Reação de Redução do Oxigênio (RRO) que ocorre no cátodo. Os processos químicos que contribuem para as perdas de ativação são complexos e envolvem a adsorção das espécies reagentes, a transferência dos elétrons através da dupla camada, a dessorção das espécies produzidas, a natureza da superfície do eletrodo, entre outros. Neste tipo de polarização, a queda de potencial em função da corrente ocorre exponencialmente e pode ser determinada pela equação de Butler-Volmer [4,5].

A polarização por queda ôhmica está relacionada à resistência ôhmica dos componentes da célula a combustível, principalmente à resistência ao transporte dos íons $\left(\mathrm{H}^{+}\right)$pela membrana e ao transporte de elétrons pelas placas condutoras e pelo circuito externo. Nestas situações, o potencial diminui de modo linear com o aumento da corrente elétrica, pois este efeito é governado pelas leis de condutância eletrolítica (lei de Ohm) $[4,5]$.

A polarização por difusão é causada, principalmente, pelo esgotamento das espécies reagentes na interface do eletrodo com o eletrólito, uma vez que os processos de difusão são mais lentos que os processos de transferência de elétrons em correntes elevadas [4,5].

Ao se submeter uma célula a combustível a diversos valores de corrente elétrica, é possível medir a diferença de potencial para cada valor de corrente. A partir deste procedimento, pode-se construir um gráfico do potencial elétrico em função da corrente elétrica (ou da densidade de corrente elétrica, a qual é dada em ampères por centímetro ao quadrado e mostra um resultado independente da área geométrica da célula). Neste gráfico, podem ser observados os efeitos da polarização assim como o tipo de polarização que está ocorrendo de modo predominante em cada limiar de corrente. Na Figura 4 é apresentado um gráfico típico da dependência do potencial elétrico com a densidade de corrente para uma célula a combustível do tipo PEM. Esta curva característica é chamada de curva de polarização [4,5]. Curvas de polarização são muito usadas na avaliação do desempenho das células a combustível. 


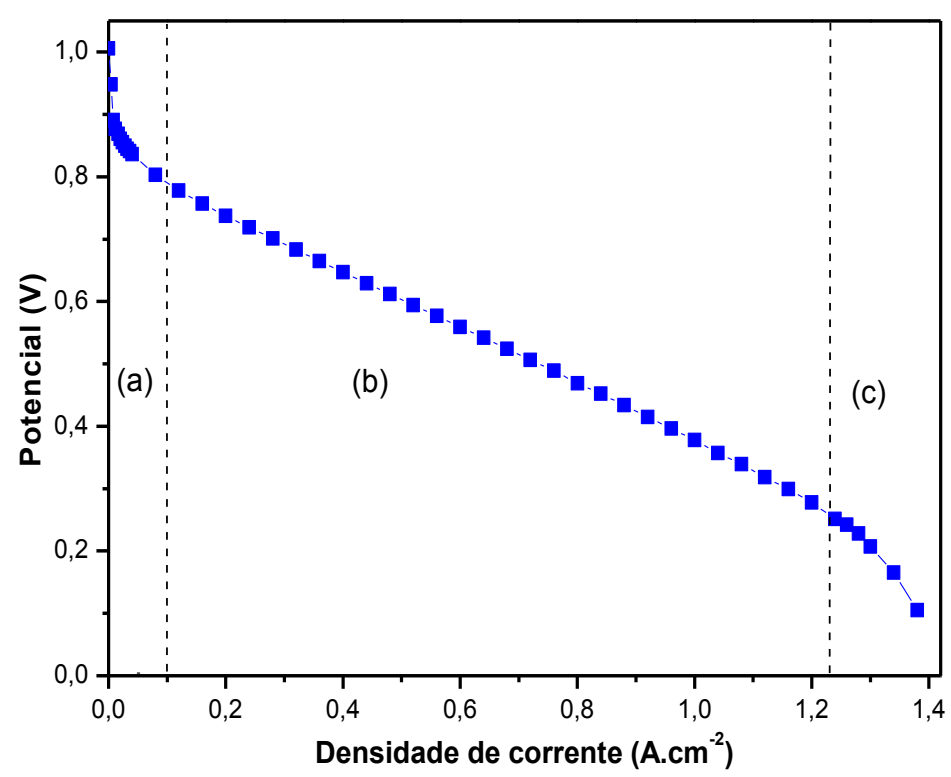

Figura 4 - Exemplo de curva de polarização de uma célula a combustível do tipo PEM. Na região (a) predomina a polarização por ativação, na região (b) pode ser observada a polarização por queda ôhmica e na região (c), destaca-se a polarização por difusão.

\subsection{Durabilidade de células a combustível do tipo PEM}

Apesar dos grandes progressos alcançados durante os últimos anos, custo e durabilidade ainda são os grandes desafios a serem vencidos para a entrada definitiva da tecnologia de células a combustível no mercado. Segundo o Departamento de Energia dos Estados Unidos (United States Department Of Energy - U.S. DOE) [10], apenas quando o custo energético das células a combustível do tipo PEM estiver abaixo de $\$ 50 \mathrm{~kW}^{-1}$ é que esta tecnologia poderá competir com todos os outros tipos de fontes energéticas. Por outro lado, para que as células a combustível do tipo PEM possam ser aplicadas em veículos automotivos, elas precisam ser tão duráveis e confiáveis quanto os motores a combustão interna utilizados nos veículos atuais, o que corresponde a uma vida útil mínima de 5000 horas de operação, considerando todas as condições de operação. Para as aplicações estacionárias, o tempo de vida das células a combustível do tipo PEM deve superar 40000 horas para entrar em competição com os sistemas atuais de geração de energia. Entretanto, os atuais tempos de vida das células a combustível do tipo PEM para aplicação veicular e estacionária estão em torno de 1.700 e 10.000 horas, respectivamente [11].

Os estudos de durabilidade são fundamentais no desenvolvimento das células a combustível, uma vez que têm por objetivo investigar os mecanismos de degradação e falha e, consequentemente, auxiliar na busca da solução destes problemas. Além dos materiais usados e dos procedimentos adotados na produção das células a combustível, as condições de operação a que são submetidos estes dispositivos eletroquímicos também são 
de suma importância para o controle de sua durabilidade. Sabe-se que as condições operacionais podem ter efeitos diretos no desempenho e na vida útil das células a combustível.

Embora a perda do desempenho ao longo da vida útil de uma célula a combustível seja inevitável, a taxa de queda deste desempenho pode ser minimizada se os mecanismos de degradação e falha puderem ser conhecidos e tratados adequadamente. As metas indicadas na literatura para as taxas de queda de desempenho de células a combustível do tipo PEM, para a maioria das aplicações, estão em torno de $2-10 \mu \mathrm{Vh}^{-1}$, e a perda de desempenho ao final da vida útil não deve ser superior a $20 \%$ do desempenho inicial [11].

\subsection{Justificativa do trabalho}

Em São Paulo, no Instituto de Pesquisas Energéticas e Nucleares (IPEN) tem-se, desde o ano 2000, uma linha de pesquisa na área de fontes energéticas eficientes e de baixo impacto ambiental, incluindo a análise e desenvolvimento de sistemas associados à tecnologia de células a combustível. Com a evolução destas pesquisas, desenvolveu-se, com muito sucesso em termos de eficiência, uma técnica especial de impressão à tela para a fabricação de MEAs para uso em células a combustível do tipo PEM. Nos estudos realizados, estes MEAs apresentaram altas densidades de corrente, quando usados em células a combustível do tipo PEM para operação com $\mathrm{H}_{2}$ e $\mathrm{O}_{2}$ [12-15]. Entretanto, estas pesquisas têm dado um enfoque maior à otimização dos custos e maximização da eficiência, além de, obviamente, ao estudo de aumento da área geométrica dos eletrodos e da escala de produção.

Para efeito deste trabalho, partiu-se do pressuposto que estes MEAs apresentam padrões elevados de eficiência. Daí a necessidade de se desenvolver um estudo que abordasse o aspecto da durabilidade das células a combustível do tipo PEM montadas com os MEAs produzidos no IPEN. 


\section{OBJETIVOS}

O objetivo principal deste trabalho é o estudo da durabilidade dos conjuntos eletrodo-membrana-eletrodo (MEAs) desenvolvidos no IPEN pelo método de impressão à tela (Sieve Printing) e usados na montagem de células a combustível do tipo PEM. Estes MEAs possuem $25 \mathrm{~cm}^{2}$ de área, são preparados com membranas poliméricas de $127 \mu \mathrm{m}$ de espessura e catalisador de platina suportada em carbono. Com base em estudos anteriores realizados no IPEN, as células a combustível produzidas com estes MEAs apresentavam ótima eficiência e reprodutibilidade, considerando sua operação com $\mathrm{H}_{2}$ e $\mathrm{O}_{2}$.

Como objetivo específico, devem ser desenvolvidos protocolos de testes de durabilidade que sejam adequados para se estimar a perda de desempenho ao longo do tempo dos MEAs das células a combustível do tipo PEM. 


\section{REVISÃO DA LITERATURA}

\subsection{Métodos de análise da durabilidade de células a combustível do tipo PEM}

Em geral, os métodos de análise empregados nos estudos de durabilidade de células a combustível do tipo PEM são definidos de acordo com o modo de falha que se quer analisar ou com o tipo de aplicação do dispositivo. Assim, podem ser aplicados testes em que se estressa propositalmente algum determinado componente da célula a combustível para que os mecanismos de degradação relacionados a este componente sejam elucidados. Por outro lado, existem testes em que as condições reais de operação do dispositivo são simuladas para que, com isto, o tempo de vida da célula a combustível em sua aplicação normal seja estimado $[11,16]$.

Um teste no qual se usa um fator de estresse sobre um determinado componente é chamado de Teste de Estresse Acelerado (TEA), pois os processos de degradação do componente estudado são induzidos para ocorrerem de forma acelerada. Neste sentido, num TEA, deve-se ativar o modo de falha de um componente específico e, ao mesmo tempo, minimizar os efeitos de modos de falha de outros componentes que possam confundir o objetivo do estudo. Logo, as condições e os parâmetros de entrada dos TEAs são determinados de forma a isolar os modos de falha que não sejam o objetivo do estudo em questão. Por exemplo, um protocolo de TEA aplicado na avaliação do carbono suporte do catalisador é diferente do protocolo utilizado no estudo do catalisador, pois estes componentes experimentam diferentes mecanismos de degradação sob condições distintas. Similarmente, um TEA específico para o estudo da degradação mecânica da membrana polimérica deve isolar os efeitos causados pela degradação química deste mesmo componente. Outro cuidado a ser tomado no desenvolvimento dos TEAs é o de garantir que os procedimentos e as condições dos testes não insiram novos mecanismos de degradação, ou seja, deve-se evitar a ocorrência de modos de falha que não apareceriam durante a operação da célula a combustível em condições normais [11, 16].

Um teste realizado em condições normais de operação e cujo objetivo final é avaliar o tempo de vida da célula a combustível como um todo é chamado, na literatura específica da área, de Teste de Durabilidade (TD). Os Testes de Durabilidade de Longa Duração (TDLD), os quais constituem uma das principais etapas dos estudos de durabilidade apresentados neste trabalho, consistem em se manter a célula a combustível em operação por centenas, ou até milhares de horas, simulando condições de aplicações práticas, tais como aplicações estacionárias (aquelas em que os parâmetros de operação, em geral, são 
mantidos estáveis) e automotivas (na qual a demanda por potência elétrica sofre várias oscilações). Estes testes também podem ser aplicados para se investigar os mecanismos de degradação de cada componente das células a combustível separadamente, ao longo do tempo. Neste caso, ocorre uma simulação das condições normais de degradação, sem a presença de fatores de aceleração de mecanismos de falha.

De qualquer forma, recomenda-se que os protocolos de TDLD, assim como os de TEA devem ser desenvolvidos de forma a garantir que as condições em que são aplicados estes testes não introduzam novos mecanismos de falhas nas células a combustível, ou seja, falhas que não estejam associadas às condições reais de operação destes dispositivos [11, $16]$.

Finalmente, a padronização dos testes de durabilidade é de crucial importância para os estudos desta área, pois permite que os resultados obtidos para os diversos itens em estudo sejam comparados $[11,17]$.

\subsection{Mecanismos de degradação da camada catalítica do eletrodo de difusão gasosa da célula a combustível do tipo PEM}

A degradação da camada catalítica está diretamente relacionada com a estrutura e os materiais que a compõem. A migração, aglomeração e o crescimento das partículas de Pt, bem como a corrosão do carbono suporte, a lixiviação e o envenenamento do catalisador são os principais fenômenos relacionados à degradação deste componente essencial de uma célula a combustível do tipo PEM [11, 16, 18].

Com relação ao crescimento e a aglomeração das partículas de $\mathrm{Pt}$, muitos mecanismos têm sido propostos. Pequenas partículas de $\mathrm{Pt}$ podem se deslocar e se depositar novamente na superfície de partículas maiores, levando, assim, ao crescimento das partículas. Este fenômeno é chamado de Ostwald ripening. Além disso, o movimento browniano e as colisões aleatórias entre estas partículas podem causar a aglomeração das mesmas sobre o carbono suporte. Esta aglomeração resulta na diminuição na energia livre de Gibbs, o que também favorece o crescimento das partículas de Pt. Este crescimento tem como consequência a diminuição da superfície catalítica ativa, levando à diminuição da atividade e da estabilidade do catalisador [16, 19].

Por outro lado, a migração de Pt ocorre quando algumas partículas deste elemento se difundem através da fase de ionômero e, subsequentemente, se precipitam na membrana. Isto ocorre devido à redução dos íons de Pt por meio do cruzamento (crossover) de 
hidrogênio oriundo do ânodo, o que reduz drasticamente a estabilidade e a condutividade da membrana [11].

A corrosão do carbono suporte ocorre por meio da oxidação eletroquímica do carbono conforme a equação (5) [20]:

$$
\mathrm{C}+2 \mathrm{H}_{2} \mathrm{O} \rightarrow \mathrm{CO}_{2}+4 H^{+}+4 e^{-}\left(E^{0}=0,207 V_{R H E}\right)
$$

Apesar da instabilidade termodinâmica do carbono, a corrosão do carbono durante a operação da célula a combustível é desprezível em potenciais abaixo de 1,1 V vs. RHE. Entretanto, a presença de Pt pode catalisar a reação de oxidação do carbono e reduzir seu potencial para $0,55 \mathrm{~V}$ vs. RHE ou a valores menores que este. Acredita-se que a corrosão do carbono ocorre nos ciclos de acionamento / desligamento do sistema de célula a combustível e em condições de falta de combustível. Os procedimentos de acionamento / desligamento do sistema de célula a combustível podem levar a uma distribuição não uniforme do combustível no ânodo. Nestas circunstâncias, o ânodo fica apenas parcialmente coberto com hidrogênio, fazendo com que o potencial do ânodo se torne negativo e, consequentemente, acabe por induzir a uma corrosão do carbono $[11,16,21]$.

\subsection{Mecanismos de degradação da membrana polimérica da célula a combustível do tipo PEM}

Em uma célula a combustível do tipo PEM, a membrana polimérica é prensada entre os dois eletrodos para transportar prótons, agir como material dielétrico, suportar as camadas catalíticas e, principalmente, separar as atmosferas oxidante e redutora no ânodo e no cátodo, respectivamente. As membranas mais utilizadas são as perfluoradas na forma ácida (perfluorosulfonic acid - PFSA), tais como as membranas Nafion ${ }^{\circledR}$.

Muitos estudos têm sido realizados acerca dos mecanismos de degradação da membrana, e sabe-se que estes ocorrem por via química, térmica e mecânica. A degradação química origina-se, principalmente, do ataque químico dos radicais de peróxido de hidrogênio, os quais são formados pelo crossover dos gases para o lado oposto da membrana, e tem como consequência o rompimento do esqueleto polimérico da membrana e dos grupos de cadeias laterais. Este fenômeno causa a perda de resistência mecânica e condutividade protônica da membrana, aumentando a resistência ôhmica e diminuindo o desempenho da célula. A degradação térmica ocorre, em geral, quando a membrana sofre mudanças morfológicas em temperaturas acima daquela em que ocorre a transição vítrea 
do polímero de PFSA, ou seja, acima de $80^{\circ} \mathrm{C}$, o que causa rupturas nas cadeias poliméricas e uma consequente diminuição na condução protônica. A degradação mecânica inclui trincas, rasgos e pequenos furos causados, geralmente, pela introdução de pequenos fragmentos estranhos ou fibras no processo de fabricação do MEA. Além disso, durante a operação da célula a combustível, a heterogeneidade na umidificação e má distribuição térmica são fatores que intensificam a degradação mecânica, uma vez que a membrana experimenta, nestas condições, tensões não uniformes em sua estrutura planar $[16,22,22,23]$.

\subsection{Mecanismos de degradação das placas monopolares das células a combustível do tipo PEM}

As placas monopolares são responsáveis por distribuir uniformemente os gases reagentes, coletar a corrente elétrica produzida pelas reações eletroquímicas e purgar o excesso de água e dos reagentes de uma célula a combustível unitária do tipo PEM. Assim, as placas monopolares devem apresentar baixa resistência ôhmica, pequena permeabilidade aos gases, alta resistência à corrosão, boa estabilidade térmica e química, e características mecânicas apropriadas. Muitos materiais têm sido empregados e analisados na fabricação de placas monopolares de células a combustível do tipo PEM, tais como grafite, metais, polímeros e compósitos. Grafite e compósitos de grafite possuem boas propriedades, tais como alta resistência à corrosão e ao ataque químico, baixa densidade, e alta condutividade elétrica e térmica. No entanto, em condições extremas, o carbono da superfície das placas monopolares pode sofrer corrosão caso ocorra, por exemplo, inversão do potencial da célula devido à falta de algum dos gases reagentes. Por outro lado, nas placas de metal, dependendo da natureza do metal, podem ocorrer corrosão e formação de um filme de óxido na superfície, gerando espécies contaminantes e aumentando sua resistência de contato $[19,22,24]$.

\subsection{Considerações gerais sobre fatores que afetam a durabilidade de células a combustível do tipo PEM}

A durabilidade dos componentes de células a combustível do tipo PEM pode ser afetada por vários fatores, tais como: condições operacionais do sistema (umidificação, temperatura de operação, potencial elétrico da célula a combustível etc.), contaminação por impurezas nos gases reagentes, mudanças bruscas no modo de operação e configuração da célula a combustível [16, 22,24]. 
As mudanças na umidade relativa e na temperatura de operação da célula a combustível, associadas às transições entre altos e baixos níveis de potência elétrica, podem causar efeitos adversos nos componentes da célula a combustível e, por consequência, na integridade do sistema como um todo. Por exemplo, sabe-se que com o aumento da umidade relativa na célula a combustível do tipo PEM, a absorção de água pela membrana polimérica também aumenta, fazendo com que o ionômero ganhe volume, o que pode resultar em fadiga e numa possível falha na membrana [21, 23, 25, 26].

A contaminação por impurezas pode ter um efeito irreversível no desempenho e na durabilidade da célula a combustível. Impurezas, tais como $\mathrm{CO}$ e $\mathrm{H}_{2} \mathrm{~S}$, podem estar presentes no $\mathrm{H}_{2}$ como resultado do processo de reforma, ou na entrada de ar, devido à poluição, na forma de $\mathrm{NO}_{\mathrm{x}}, \mathrm{SO}_{\mathrm{x}}$ ou de compostos orgânicos. Além disso, os próprios componentes da célula a combustível podem liberar substâncias contaminantes, tais como íons metálicos ou resíduos orgânicos decorrentes do processo de manufatura. Possíveis efeitos destas impurezas no desempenho e na durabilidade das células a combustível são: bloqueio irreversível dos sítios catalíticos, tornando-os inativos e diminuindo a cinética das reações eletroquímicas; mudanças na hidrofobicidade da camada catalítica ou difusora, afetando a transferência de massa; e perda da condutividade, tanto dos eletrodos como da membrana $[11,16,22]$.

Mudanças no modo de operação do sistema, tais como o acionamento / desligamento e as variações bruscas de potencial elétrico, podem afetar drasticamente a durabilidade das células a combustível. Por exemplo, quando o sistema de célula a combustível é mantido desligado por muito tempo, o hidrogênio remanescente nas linhas do sistema pode atravessar a membrana do lado do ânodo para o cátodo, fazendo com que os canais difusores do ânodo, eventualmente, encham-se de ar. Ao ser religado, o sistema passa por uma condição transitória, na qual haverá $\mathrm{H}_{2}$ nos canais de entrada do ânodo e ar nos canais próximos a saída deste mesmo eletrodo. A mistura destes gases num mesmo eletrodoível poderá induzir a um potencial elétrico maior que $1,8 \mathrm{~V}$ no cátodo, causando uma degradação acentuada e reduzindo a durabilidade da célula a combustível [26-29].

O projeto das várias partes que compõem uma célula a combustível do tipo PEM e, principalmente, a configuração dos canais difusores da placa monopolar podem ter um impacto significativo no gerenciamento da água e na distribuição dos gases para o MEA. Uma configuração inadequada dos canais difusores pode induzir ao bloqueio dos mesmos com água, o que resulta numa distribuição insuficiente dos gases reagentes, podendo levar a corrosão do carbono suporte pelos mecanismos de corrente reversa [16, 19, 24, 30]. 


\section{METODOLOGIA}

A metodologia adotada no desenvolvimento deste estudo pode ser dividida em duas partes principais:

PARTE I - MÉTODOS USADOS NA PRODUCCÃO DOS CONJUNTOS ELETRODOMEMBRANA-ELETRODO, MONTAGEM DAS CÉLULAS A COMBUSTÍVEL DO TIPO PEM E DESENVOLVIMENTO DOS TESTES DE DURABILIDADE

Nesta parte são descritos com detalhes os vários procedimentos seguidos no laboratório do IPEN para a produção dos MEAs até a montagem final da célula a combustível do tipo PEM. Estes procedimentos estão baseados em técnicas que vêm sendo consolidadas neste instituto e foram temas de vários trabalhos desenvolvidos nesta área [12-15]. Com relação aos testes de durabilidade executados durante este estudo, são descritos os recursos laboratoriais usados, a montagem dos testes e os protocolos especialmente elaborados para se estudar o desempenho da célula a combustível do tipo PEM, considerando sua operação por um longo período de tempo em estado estacionário.

\section{PARTE II - MÉTODOS USADOS PARA ANÁLISE DOS RESULTADOS OBTIDOS NOS TESTES DE DURABILIDADE DAS CÉLULAS A COMBUSTÍVEL DO TIPO PEM}

Nesta parte é descrita a abordagem adotada na análise dos resultados obtidos nos testes de durabilidade das células a combustível do tipo PEM, que consistiu numa combinação de métodos, os quais foram aplicados de modo complementar, para se chegar às conclusões obtidas neste estudo. Assim, a metodologia de análise abrangeu: análise estatística dos dados de potencial elétrico da célula a combustível em função do tempo; análise comparativa das curvas de polarização construídas no início e no final do teste de durabilidade de longa duração; e análise comparativa, por meio de microscopia eletrônica de transmissão, das características morfológicas do catalisador usado nos MEAs antes e após os testes de durabilidade de longa duração. 


\subsection{PARTE I - Métodos usados na produção dos conjuntos eletrodo-membrana- eletrodo, montagem das células a combustível do tipo PEM e desenvolvimento dos testes de durabilidade}

\subsubsection{Produção dos conjuntos eletrodo-membrana-eletrodo (MEAs) para células a combustível do tipo PEM}

\subsubsection{Tratamento químico da membrana condutora de prótons}

As membranas poliméricas utilizadas nas células a combustível do tipo PEM testadas para este trabalho foram fabricadas pela empresa DuPont e são vendidas comercialmente com o nome de Nafion ${ }^{\circledR}$. As membranas Nafion ${ }^{\circledR} 115$ possuem, em média, $127 \mu \mathrm{m}$ de espessura, conforme especificação do fabricante. No entanto, para que estas membranas funcionem como condutoras de prótons $\left(\mathrm{H}^{+}\right)$, faz-se necessário um tratamento químico das mesmas para a substituição das estruturas que se encontram na forma sódica $\left(\mathrm{Na}^{+}\right)$para a forma ácida $\left(\mathrm{H}^{+}\right)$e para a retirada de impurezas orgânicas e inorgânicas.

A seqüência de procedimentos para o tratamento das membranas é descrita a seguir $[13,14]$ :

$\checkmark$ Corte das membranas nas dimensões desejadas. Para os MEAs deste trabalho, cuja área mede $25 \mathrm{~cm}^{2}$, as membranas foram cortadas com medidas de $10 \mathrm{~cm} \mathrm{x}$ $10 \mathrm{~cm}$, ou seja, ligeiramente maiores que a área dos MEAs;

$\checkmark$ Imersão das membranas em banho de peróxido de hidrogênio diluído em água ultra-pura (3\% em volume) a $80{ }^{\circ} \mathrm{C}$ durante 1 hora, para a remoção de impurezas orgânicas;

$\checkmark$ Três etapas de lavagem em água ultra-pura a $80^{\circ} \mathrm{C}$, para a remoção de resíduos orgânicos;

$\checkmark$ Imersão das membranas em uma solução de 0,5 mol. $\mathrm{L}^{-1}$ de ácido sulfúrico (diluído em água ultra-pura) a $80^{\circ} \mathrm{C}$ para, além de eliminar as impurezas metálicas das membranas, acidificar as mesmas, ou seja, substituir as estruturas de $\mathrm{Na}^{+}$por $\mathrm{H}^{+}$;

$\checkmark$ Novamente, mais três etapas de lavagem em água ultra-pura a $80^{\circ} \mathrm{C}$, para a remoção do ácido e dos resíduos metálicos.

Após estes procedimentos, as membranas são armazenadas em água ultra-pura [13, 14]. 


\subsubsection{Produção dos Eletrodos de Difusão Gasosa (EDGs)}

\subsection{Preparo da Tinta Precursora da Camada Catalítica (TPCC)}

A confecção da camada catalítica dos MEAs foi feita por meio da técnica de impressão à tela. Para tanto, é necessário o preparo da Tinta Precursora da Camada Catalítica (TPCC), composta por massa sólida (mistura de catalisador e dispersão de Nafion $^{\circledR}$ ) e solventes. Quando a TPCC é aplicada no eletrodo, os solventes evaporam e, no final do processo, resta somente a mistura de catalisador e Nafion ${ }^{\circledR}$. A TPCC preparada para este trabalho segue a formulação proposta na literatura [15].

A TPCC foi preparada a partir da mistura do catalisador de platina suportado em carbono (Pt/C - BASF) contendo $20 \%$ de Pt, solução de Nafion ${ }^{\circledR}$ D520 da Dupont(solução de $5 \%$ em massa) e solventes orgânicos (Etileno Glicol e 1-Heptanol). Para a massa sólida, a proporção adotada entre catalisador Pt/C e Nafion ${ }^{\circledR}$ seco foi de 65:35 em massa. Para os solventes, a proporção adotada foi de 97:3 em massa de Etileno Glicol e 1Heptanol. Já a relação entre a massa seca (catalisador e Nafion ${ }^{\circledR}$ ) e a massa de solventes foi controlada para que ficasse em torno de 0,3, ou seja, $30 \%$ da massa total deve corresponder à massa de sólidos.

O preparo da TPCC foi realizado misturando-se em um dispersor de alta rotação (12.000 a $15.000 \mathrm{rpm}$ ), os solventes com a solução de Nafion ${ }^{\circledR}$ e água ultra-pura, causando a formação de um turbilhão no centro do béquer e permitindo que a adição do catalisador seja feita sem risco de combustão. Isto pode assegurado pelo fato do catalisador não entrar em contato com os solventes da solução e com o oxigênio do ar por muito tempo, pois é submerso rapidamente na mistura pela ação do turbilhão formado no béquer.

Após a adição e mistura de todos os componentes da TPCC, o processo de agitação seguiu por cerca de 15 minutos, com uma pausa de alguns minutos para ambientação e, após o resfriamento, a mistura foi novamente submetida à agitação por mais 15 minutos. Em seguida, a TPCC foi inserida em um béquer sobre um agitador magnético, o qual manteve uma agitação mínima (entre 40 e $60 \mathrm{rpm}$ ) na mistura, enquanto o processo de aquecimento era realizado para remoção dos solventes e concentração da massa sólida. Durante o processo de remoção dos solventes, a temperatura foi mantida entre $80{ }^{\circ} \mathrm{C}$ e $110{ }^{\circ} \mathrm{C}$. Ao final do processo, alíquotas da mistura foram retiradas para controle de seu teor de sólidos e o aquecimento foi suspenso assim que o teor de sólidos desejado foi obtido [15]. 


\subsection{Aplicação da TPCC por meio da técnica de impressão à tela}

A técnica de Impressão à Tela, cujo termo usado em inglês é "Sieve Printing", possui algumas vantagens sobre as técnicas convencionais, principalmente no que diz respeito à rapidez para sua execução e à excelente reprodutibilidade da morfologia do eletrodo e, por consequiência, do MEA. De maneira geral, esta técnica consiste em se pressionar a TPCC através de uma tela ou malha para uma superfície abaixo. Os itens essenciais para se fazer uma Impressão à Tela são: uma tela, incluindo uma armação no qual fica esticada uma malha; um estêncil de fotografia do desígnio exigido, preso à malha; um rodo, o qual é provido de uma lâmina flexível e elástica; uma tinta ou pasta; uma base segura, sobre a qual se posiciona o componente a ser impresso; e o operador, o qual deve estar capacitado para combinar estes cinco itens de modo adequado [12-15].

Na Figura 5 é mostrado um esquema simplificado do princípio de funcionamento da técnica. A malha da tela é colocada em contato com o substrato pelo rodo, o qual é movido através da tela. A tinta é empurrada na área aberta que forma a matriz e o excesso é afastado pela extremidade do rodo. Em seguida, a tela pode ser erguida facilmente, sem risco da impressão ser deteriorada.

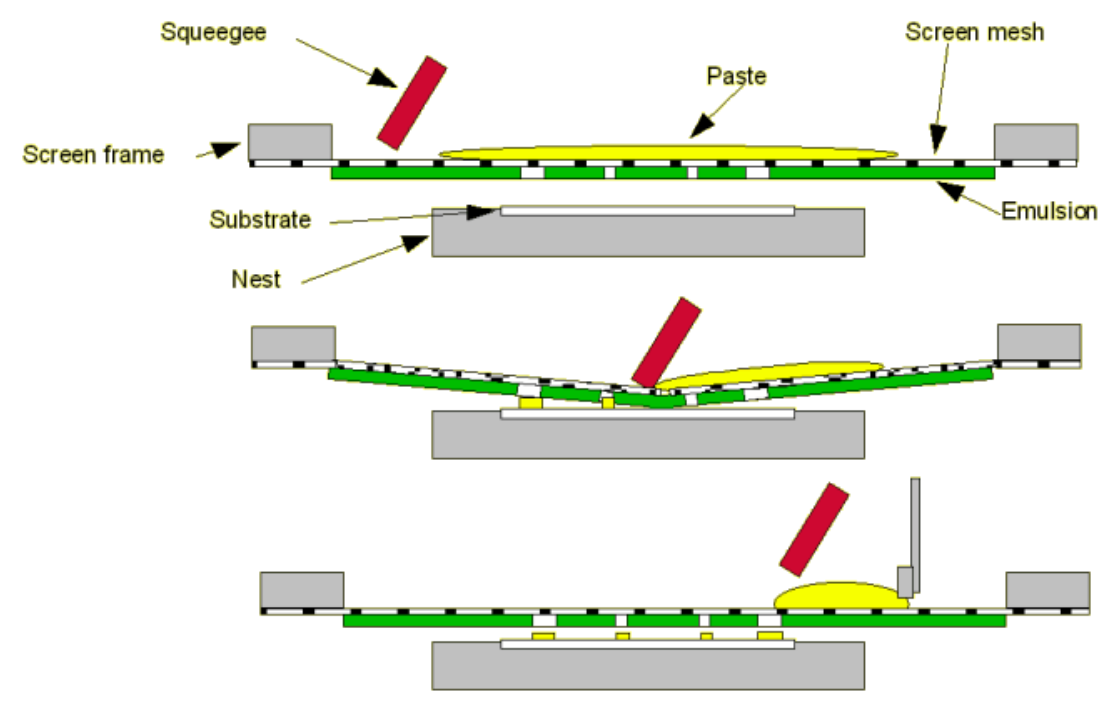

Figura 5- Processo básico de Impressão à Tela [15].

A aplicação da TPCC por impressão à tela para o preparo dos EDGs foi realizada numa máquina de impressão modelo E1, fabricada pela empresa EKRA e adquirida pelo IPEN. Nesta máquina, a pressão e a velocidade de impressão podem ser ajustadas, além de contar com um sistema de vácuo capaz de fazer uma fixação melhor do substrato e um sistema de vídeo para fazer, quando necessário, o controle da sobreposição das camadas de 
impressão por meio de imagens [12-16]. Na Figura 6 é apresentada uma fotografia da máquina de impressão modelo E1 da EKRA.

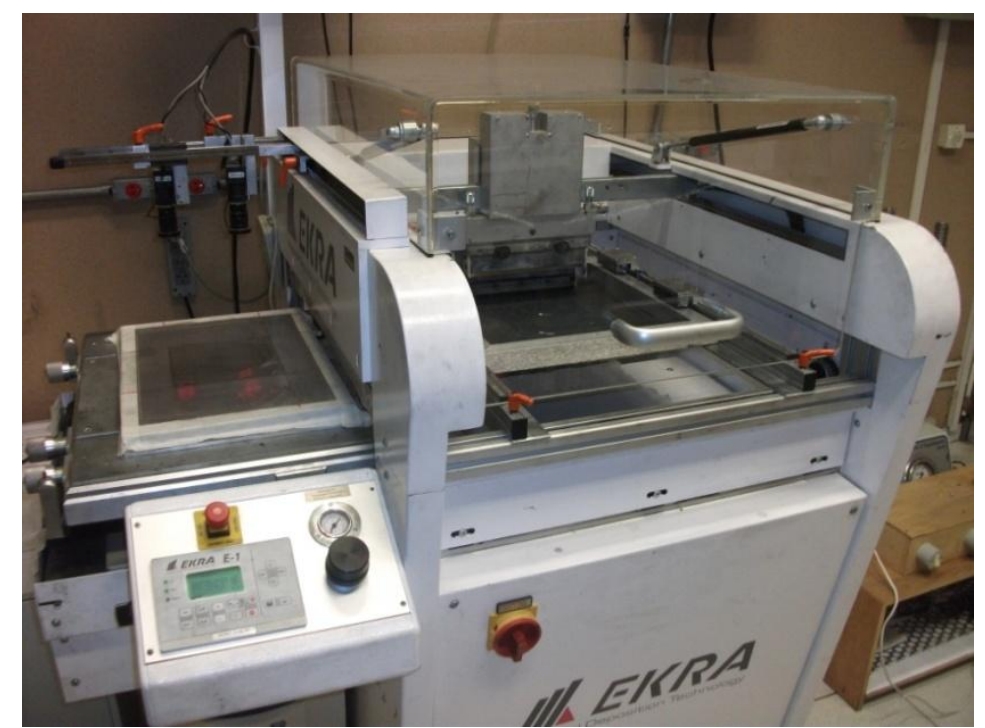

Figura 6 - Máquina de impressão à Tela modelo E1 da empresa EKRA.

O substrato para a aplicação da TPCC usado para este trabalho foi o tecido de carbono teflonado ("Electrode Backing") EC-CC1-060T, produzido pela empresa Electrochem. Os parâmetros para ajuste da máquina de impressão E1 foram definidos conforme descrito em trabalho prévio [15], considerando valores já otimizados.

\subsubsection{Prensagem dos conjuntos eletrodo-membrana-eletrodo (MEAs)}

A prensagem é a última etapa de preparação do MEA. Nesta etapa, os componentes do MEA são unidos por meio da aplicação de pressão e calor, por um determinado período de tempo. As temperaturas do processo de prensagem, bem como a pressão, variam conforme as dimensões do MEA. Os parâmetros de prensagem adotados para este trabalho, considerando que os MEAs produzidos apresentam $25 \mathrm{~cm}^{2}$ de área, foram extraídos de um trabalho prévio [15], pois podem ser considerados os melhores para MEAs destas dimensões. Os procedimentos e parâmetros adotados nesta etapa foram:

$\checkmark$ União de todos os componentes do MEA, ou seja, eletrodos de difusão gasosa, membrana condutora de prótons e espaçadores (tecidos compostos de fibra de vidro e teflon que funcionam como compensadores da espessura do EDG na região não "sanduichada" da membrana entre ânodo e cátodo) são colocados entre duas placas de aço, formando uma espécie de "sanduíche"; 
$\checkmark$ Colocação deste "sanduíche" na prancha de prensagem previamente aquecida a $105^{\circ} \mathrm{C}$

$\checkmark$ Ajuste do set-point da prensa em $125^{\circ} \mathrm{C}$. Quando a prancha atinge esta temperatura, a pressão da prensa é ajustada em $395 \mathrm{kgf.cm}{ }^{-2}$ por 10 minutos. Após este intervalo de tempo, a pressão é liberada, o "sanduíche" é retirado da prensa e colocado em uma bancada para resfriamento até a temperatura ambiente.

\subsubsection{Montagem dos conjuntos eletrodo-membrana-eletrodo (MEAs) nas células a combustível do tipo PEM}

Finalmente, o conjunto eletrodo-membrana-eletrodo (MEA), já incluindo os espaçadores, é montado junto com os demais componentes (placas monopolares, placas metálicas condutoras de elétrons, juntas de vedação, parafusos, etc.) para compor a célula a combustível do tipo PEM. Para esta etapa, os MEAs preparados no IPEN foram montados em células a combustível unitárias de $25 \mathrm{~cm}^{2}$, cujos componentes foram produzidos pela empresa brasileira Electrocell. Foram usadas quatro células a combustível idênticas, cujos componentes principais apresentam as seguintes características:

$\checkmark$ placas monopolares de grafite - dimensões 9,5 x 9,5 x 1,2 cm; configuração dos canais de fluxo do tipo serpentina; penetrações para termopares tipo $\mathrm{K}$ de 1,5 $\mathrm{mm}$ de diâmetro e resistências tubulares de $5 \mathrm{~mm}$ de diâmetro;

$\checkmark$ placas coletoras de corrente - flanges de fechamento com tratamento de superfície a base de cobre e acabamento com douração.

Nesta montagem, o torque de aperto nos parafusos das células foi de 3 N.m, pois se trata de um parâmetro otimizado [15] e adotado como padrão no laboratório.

\subsubsection{Recursos laboratoriais e montagem dos testes com as células a combustível do tipo PEM}

Para a realização dos testes com as células a combustível do tipo PEM foram usadas estações de teste automatizadas, específicas para este tipo de célula a combustível, cujo modelo é denominado Evaluator-C, fabricadas pela empresa alemã FuelCon. As principais características destas estações de teste são: controle automático dos parâmetros de operação da célula a combustível, tais como pressão, temperatura, umidificação e fluxo dos 
gases reagentes $\left(\mathrm{H}_{2}\right.$ e $\left.\mathrm{O}_{2}\right)$; atuação automática de dispositivos para aquecimento (resistências elétricas) e refrigeração (ventilador) da célula a combustível durante a operação; sistema de proteção para operação não assistida e desligamento seguro da estação de teste para ambiente com hidrogênio; preenchimento automático do volume de água nos umidificadores dos gases reagentes; resfriamento e desligamento automático do sistema com a célula a combustível ao final do teste; sistema de monitoração e atuação local e remota da estação; e programa computacional de gerenciamento da estação durante os testes, o qual permite a criação de protocolos totalmente automatizados para operação das células a combustível, incluindo aquisição de dados para análise e elaboração de gráficos. O programa computacional desenvolvido pela empresa FuelCon para gerenciamento da estação de testes Evaluator-C é denominado FuelWork .

No IPEN, encontram-se instaladas duas estações de teste do modelo Evaluator-C fornecidas pela FuelCon, conforme é mostrado na Figura 7.
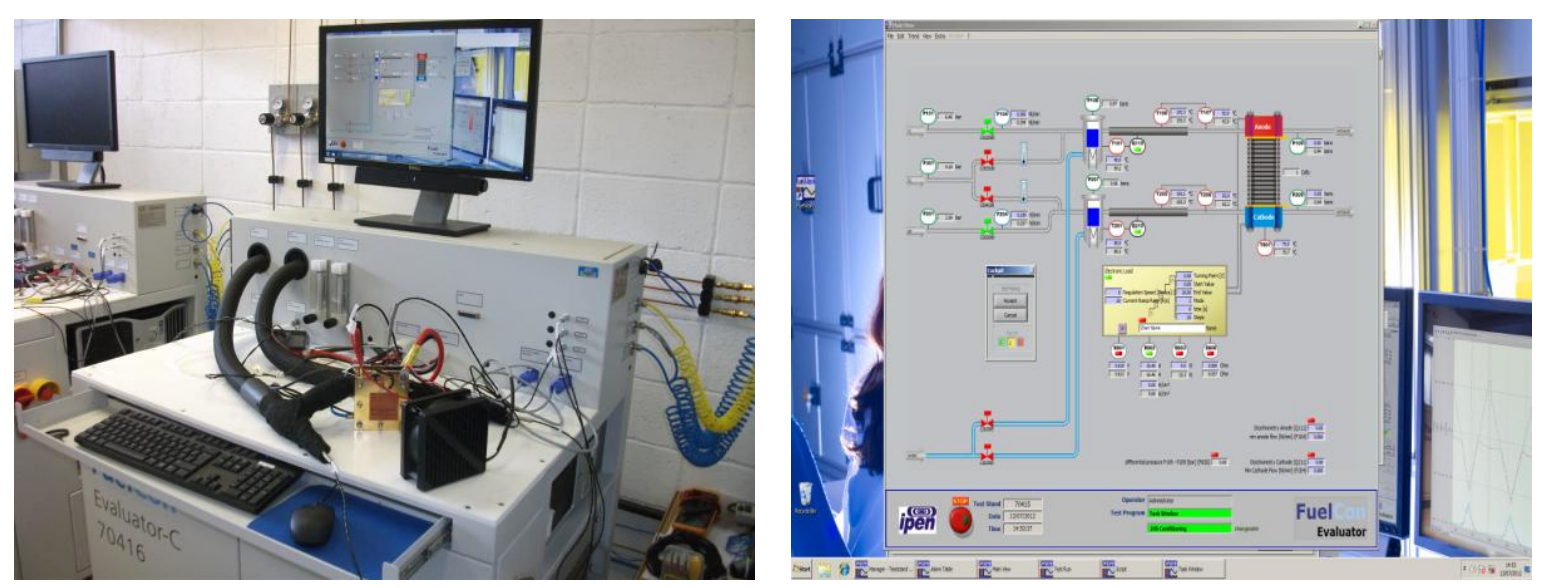

Figura 7 - a) Estações de teste Evaluator-C fornecidas pela FuelCon; b) Imagem da tela do programa computacional Fuelwork usado na operação das estações de teste.

\subsubsection{Protocolos de teste de durabilidade de longa duração com células a combustível do tipo PEM}

O estudo da durabilidade dos componentes de uma célula a combustível do tipo PEM requer a aplicação de protocolos de teste que simulem o funcionamento deste dispositivo por um longo período de tempo. Além disso, estes protocolos devem ser adequados para a avaliação do desempenho real do componente em questão, ou seja, que não introduzam novos modos de falha ou de degradação e não distorçam os resultados que podem ser obtidos. Deste modo, os protocolos de teste a serem aplicados, além de garantir as 
características mencionadas acima, devem ser consistentes o bastante para permitir a comparabilidade e a reprodutibilidade dos resultados.

Neste sentido, um dos enfoques importantes deste trabalho foi definir um protocolo de Teste de Durabilidade de Longa Duração (TDLD) que pudesse reproduzir, do modo mais realista possível, o comportamento do potencial elétrico da célula a combustível do tipo PEM ao longo do tempo. Assim, foram especificados vários procedimentos a serem seguidos para se cumprir integralmente um protocolo de TDLD, que são: aquecimento do sistema, ciclagem do potencial elétrico da célula a combustível, condicionamento da célula a combustível, estabilização dos parâmetros de operação do sistema, operação da célula a combustível em estado estacionário, resfriamento do sistema e encerramento do teste.

$\mathrm{Na}$ definição deste protocolo de TDLD tomou-se por base os protocolos de testes desenvolvidos no âmbito do projeto intitulado "Fuel Cell Systems Testing, Safety \& Quality Assurance", co-financiado pela Comissão Européia. Mais especificamente, os testes de durabilidade de longa duração foram implementados a partir do protocolo denominado Test Module PEFC SC 5-6 (Testing the voltage-power as function of time at fixed current density - Long term durability steady test for a PEFC single cell) [31]. No entanto, pelo fato desse protocolo não fornecer detalhes específicos dos parâmetros e procedimentos a serem adotados e considerando a infraestrutura disponível no IPEN e a realidade prática para execução de testes contínuos e de longa duração, foi necessário fazer alguns ajustes neste protocolo de referência [31] para que os resultados pudessem apresentar a qualidade desejada. De um modo geral, os protocolos de TDLD propostos neste estudo seguem os seguintes procedimentos:

1. Purga da célula a combustível com $\mathbf{N}_{2}$ : realiza-se, inicialmente, uma purga da célula a combustível com nitrogênio a fim de se eliminar resíduos contaminantes que podem ter permanecido durante a confecção do MEA ou na montagem da célula a combustível;

2. Partida do sistema / aquecimento da célula a combustível: abrem-se, neste procedimento, as válvulas de $\mathrm{H}_{2}$ e $\mathrm{O}_{2}$ e ajustam-se os fluxos dos mesmos. Além do mais, inicia-se o aquecimento dos umidificadores dos gases reagentes e da célula a combustível por meio de resistências elétricas inseridas nas plcas de grafite; 
3. Ciclagem do potencial elétrico da célula a combustível: este procedimento consiste em simular, por diversas vezes, variações rápidas do potencial elétrico da célula a combustível, partindo-se do potencial de circuito aberto (corrente elétrica nula) até um valor de potencial pré-determinado (valores mais elevados de corrente elétrica), a fim de se ativar os sítios catalíticos do MEA;

4. Estabilização das condições de operação da célula a combustível: fixa-se, na carga dinâmica, um valor de corrente elétrica, cujo valor é definido de modo que o potencial elétrico da célula a combustível pra essa corrente fique, inicialmente, em torno de $600 \mathrm{mV}$. Feito isto, espera-se algumas horas para começar o teste propriamente dito. Para este trabalho, foi estabelecido que o sistema pode ser considerado estável se a variação do potencial elétrico da célula a combustível na última hora de observação for menor do que $10 \%$ do seu valor no início deste período, ou seja, variações menores que $6 \mathrm{mV} \cdot \mathrm{h}^{-1}$;

5. Levantamento da curva de polarização inicial: a curva de polarização inicial, mostrando o comportamento do potencial elétrico da célula a combustível em função da densidade de corrente, é construída após a estabilização das condições operacionais do sistema e deve ser comparada com a curva de polarização elaborada ao final do teste, para auxiliar no diagnóstico de uma possível perda de desempenho da célula. $O$ procedimento de obtenção das curvas de polarização foi definido conforme um protocolo proposto na literatura [32] que faz parte do mesmo projeto que desenvolveu o protocolo de TDLD utilizado;

6. Realização do teste específico - teste de longa duração com o sistema em estado estacionário: o teste é realizado mantendo-se constantes, por um período de tempo determinado, todas as variáveis de entrada do sistema, inclusive a corrente elétrica drenada da célula a combustível, com base nas condições operacionais do sistema alcançadas no Procedimento 4. Durante este período em que o sistema opera em estado estacionário, são feitas medições adequadas das variáveis de saída de interesse para este trabalho. O principal objetivo é obter dados que permitam uma análise da variação do potencial elétrico da célula a combustível ao longo do tempo;

7. Levantamento da curva de polarização final: conforme mencionado no Procedimento 5, as curvas de polarização inicial e final podem ser comparadas para auxiliar no diagnóstico de uma possível perda de desempenho da célula ao longo do teste; 
8. Desligamento do sistema / resfriamento da célula a combustível: antes de se efetuar o desligamento do sistema, é recomendável executar o procedimento de purga da linha de $\mathrm{H}_{2}$ com $\mathrm{N}_{2}$, que é um procedimento similar ao efetuado no Procedimento 1.

Para se chegar a um protocolo de TDLD adequado, foi necessário ajustar o tempo de execução, a ordem e o número de vezes que cada procedimento descrito acima é aplicado. Além disso, para que a célula a combustível do tipo PEM pudesse ser observada em condições operacionais ótimas, foram sendo ajustados alguns parâmetros do sistema, especialmente aqueles considerados mais críticos em termos dos efeitos que podem ser produzidos no desempenho da célula a combustível do tipo PEM. Deste modo, os seguintes parâmetros do sistema precisaram ser ajustados no decorrer do estudo: temperatura da célula a combustível e fluxo, temperatura e umidade relativa dos gases reagentes.

É importante destacar que, para que um maior número de MEAs pudesse ser testado para este estudo, foi adotado um critério de tempo para o encerramento dos testes de durabilidade de longa duração. Assim, foi definido um tempo de 500 horas para duração do Procedimento 6 do protocolo de TDLD, ou seja, após o condicionamento da célula a combustível e estabilização do sistema, espera-se observar o comportamento da célula a combustível por pelo menos 500 horas em estado estacionário.

$\mathrm{Na}$ prática, porém, alguns problemas podem surgir em relação a aplicação dos protocolos de TDLD e que acabam implicando em interrupções não programadas durante um teste. Os eventos mais comuns são: perda do suprimento de energia elétrica da rede externa, falha em algum componente da estação de teste, erro no programa computacional de gerenciamento da operação da célula a combustível na estação de teste, etc. Dentre estas ocorrências, estão incluídos eventos que causam o desligamento automático da estação de testes, por gerarem condições que ameaçam a segurança do laboratório.

Finalmente, a implementação dos protocolos de TDLD no programa computacional FuelWork, o qual faz o gerenciamento da operação da célula a combustível do tipo PEM na estação de testes Evaluator-C, é feita por meio da elaboração de rotinas em linguagem de programação. O programa computacional FuelWork possui uma ferramenta de programação de rotinas denominada TestWorkScript, que é uma extensão da linguagem Microsoft ${ }^{\circledR}$ Visual Basic ${ }^{\circledR}$ Script (VBScript). A linguagem VBScript, por sua vez, está 
baseada na linguagem Visual Basic for Applications (VBA). O diagrama de blocos, bem como as rotinas elaboradas para implementação dos protocolos de TDLD aplicados neste trabalho encontram-se nos ANEXOS A, B, C e D.

\subsection{PARTE II - Métodos usados para análise dos resultados obtidos nos testes de durabilidade das células a combustível do tipo PEM}

\subsubsection{Análise do potencial elétrico da célula a combustível em função da densidade de corrente elétrica: curvas de polarização}

As curvas de polarização obtidas durante os testes constituem uma das técnicas usadas neste trabalho para análise do desempenho das células a combustível do tipo PEM, as quais foram montadas com os MEAs produzidos no IPEN. A partir do gráfico de uma curva de polarização, é possível extrair informações sobre o comportamento do potencial elétrico da célula (medido em Volts) em função da densidade de corrente elétrica (medida em A. $\mathrm{cm}^{-2}$ ) drenada por uma carga dinâmica. As curvas de polarização foram realizadas em condições padronizadas para que o desempenho de cada MEA pudesse ser avaliado em relação ao tempo de operação e, também, comparado com valores fornecidos por fabricantes ou publicados na literatura especializada. Geralmente, para a comparação das curvas de polarização obtidas, observa-se o valor do potencial elétrico atingido em função de um determinado valor de corrente drenada da célula. Deste modo, a curva que apresenta o melhor desempenho elétrico obtido do MEA é aquela na qual, para aquele mesmo valor de corrente elétrica, o valor do potencial é mais alto.

\subsubsection{Análise estatística da variação do potencial elétrico da célula a combustível em função do tempo}

A análise estatística dos dados obtidos nos testes de durabilidade de longa duração (TDLD) realizados com as células a combustível do tipo PEM produzidas para este trabalho foi efetuada em duas etapas principais, a saber:

\subsubsection{Etapa de análise exploratória dos dados}

Nesta etapa são elaborados os gráficos de dispersão dos pontos observados (potencial elétrico, tempo), para o período de operação da célula a combustível em estado estacionário. Cabe citar que, os pontos observados nos períodos que antecederam (Procedimentos 1, 2, 3, 4 5) ou que sucederam (Procedimentos 7 e 8) o período em que a 
célula a combustível operou em estado estacionário (Procedimento 6) não foram incluídos nestes gráficos. $\mathrm{Na}$ análise exploratória, são calculadas, também, medidas de posição e medidas de dispersão que possam ser usadas para melhor representar o desempenho da célula a combustível durante o teste. Assim, a partir dos pontos observados, podem ser calculados a média do potencial elétrico da célula a combustível no período estacionário e desvio padrão associado a esta média.

\subsubsection{Etapa de ajuste de um modelo estatístico aos dados observados}

Após a análise exploratória dos dados obtidos em cada teste, foi proposto um modelo linear para explicar a variação do potencial elétrico em relação ao tempo, considerando a operação da célula a combustível em estado estacionário. Portanto, admitindo-se que o potencial elétrico é uma função linear do tempo de operação da célula a combustível, podese estabelecer uma regressão linear simples, cujo modelo estatístico é dado por [33, 34]:

$$
U_{i}=\alpha+\beta t_{i}+e_{i}
$$

onde $U_{i}$ é o potencial elétrico da célula a combustível no instante $t_{i}, e_{i}$ é o erro associado à medida de $\mathrm{U}_{\mathrm{i}}$ e $\alpha$ e $\beta$ são os parâmetros do modelo.

Em geral, o termo "linear" refere-se ao modo como os parâmetros entram no modelo, isto é, de forma linear. Sabe-se que $\alpha$, o intercepto, representa o ponto onde a reta corta o eixo das ordenadas, ou seja, representa o potencial elétrico da célula a combustível no instante $\mathrm{t}=0$ (início do período em estado estacionário). $\mathrm{O}$ parâmetro $\beta$, o coeficiente angular da reta, representa o quanto varia a média do potencial elétrico para um aumento de uma unidade de tempo de observação [33, 34].

É importante citar que, no ajuste linear, parte-se da suposição que o erro $\mathrm{e}_{\mathrm{i}}$ associado à medida de $\mathrm{U}_{\mathrm{i}}$ é uma variável aleatória que segue uma distribuição normal com média $0 \mathrm{e}$ variância $\sigma^{2}$. Esta suposição, representada por $\mathrm{e}_{\mathrm{i}} \sim \mathrm{N}\left(0, \sigma^{2}\right)$, é necessária para demonstrar que as estimativas dos parâmetros obtidas pelo método dos mínimos quadrados são não tendenciosas.

Assim, os estimadores de mínimos quadrados para os parâmetros do modelo linear podem ser calculados pelo seguinte sistema de equações [33, 34]:

$$
\hat{\alpha}=\bar{u}-\hat{\beta} \bar{t}
$$




$$
\hat{\beta}=\frac{\sum_{i=1}^{n} t_{i} u_{i}-n \bar{t} \bar{u}}{\sum_{i=1}^{n} t_{i}^{2}-n \bar{t}^{2}}
$$

onde $\bar{u}$ e $\bar{t}$ são as médias do potencial elétrico e do tempo no período observado.Temse, ainda, que:

$$
\hat{u}_{i}=\hat{\alpha}+\hat{\beta} t_{i}
$$

onde $\hat{u}_{i}$ é o valor ajustado do potencial elétrico da célula a combustível no instante $\mathrm{t}_{\mathrm{i}}$.

Assim, a discrepância entre cada valor ajustado e valor observado do potencial elétrico é dada pelo resíduo [33, 34]:

$$
\hat{e}_{i}=u_{i}-\hat{u}_{i}
$$

A avaliação da adequação do ajuste de um modelo linear aos dados observados pode ser feita de várias formas, sendo que as mais usadas são: (i) análise de variância (ANOVA) para o modelo de regressão; (ii) cálculo do coeficiente de determinação $\mathrm{R}^{2}$, o qual indica a proporção de variação de $\mathrm{U}$ que é explicada pela regressão. Nota-se que $\mathrm{R}^{2}$ varia entre 0 e 1 , sendo que a regressão será tanto mais adequada quanto mais próximo de 1 (um) estiver o valor de $\mathrm{R}^{2}$; e (iii) análise gráfica dos resíduos, que consiste em verificar, por meio de um gráfico, as discrepâncias entre os valores observados e os valores ajustados pelo modelo de regressão [33, 34].

A Análise de Variância (ANOVA) da regressão consiste, basicamente, numa avaliação das somas dos quadrados dos erros envolvidos no ajuste do modelo linear. As informações necessárias para a aplicação de uma ANOVA são resumidas em forma de tabela, conforme apresentado na Tabela 1 a seguir [33, 34]:

Tabela 1 - Tabela ANOVA para modelo de regressão.

\begin{tabular}{cccccc}
\hline $\begin{array}{c}\text { Fonte de } \\
\text { variação }\end{array}$ & $\begin{array}{c}\text { Graus de } \\
\text { liberdade } \\
(\text { g.1. })\end{array}$ & $\begin{array}{c}\text { Soma de } \\
\text { Quadrados } \\
(\mathrm{SQ})\end{array}$ & $\begin{array}{c}\text { Quadrado Médio } \\
(\mathrm{QM})\end{array}$ & $\begin{array}{c}\text { Estatística } \\
\mathrm{F}\end{array}$ & $\begin{array}{c}\text { Prob }\left(\mathrm{F}_{\text {obs }}>\right. \\
\left.\mathrm{F}_{\mathrm{c}}\right)\end{array}$ \\
\hline Regressão & 1 & SQReg & SQReg = QMReg & QMReg/ $S_{e}^{2}$ & $\mathrm{p}$ \\
Resíduo & $\mathrm{n}-2$ & SQRes & SQRes/(n-2)= Se & & \\
Total & $\mathrm{n}-1$ & SQTot & SQTot/(n-1) $=\mathrm{S}^{2}$ & & \\
\hline
\end{tabular}


Onde:

$$
\begin{aligned}
& \mathrm{n}=\text { número de pontos observados } \\
& \text { SQReg }=\hat{\beta}^{2} \sum_{i=1}^{n}\left(t_{i}-\bar{t}\right)^{2} \\
& \text { SQRes }=\sum_{i=1}^{n}\left(u_{i}-\hat{u}_{i}\right)^{2}=S_{e}^{2} \\
& \text { SQTot }=\text { SQReg }+ \text { SQRes } .
\end{aligned}
$$

O conceito que serve de base para aplicação da ANOVA é o de um teste de hipótese que tem por objetivo verificar se o modelo de regressão linear se ajusta estatisticamente melhor aos dados do que um modelo mais simples, de ajuste pela média amostral. Este teste tem a seguinte formulação:

$$
\mathrm{H}_{0}: \beta=0 \text { contra } \mathrm{H}_{1}: \beta \neq 0 \text {, onde } \beta \text { é o coeficiente linear da reta. }
$$

Rejeitar a hipótese $\mathrm{H}_{0}: \beta=0$ equivale a aceitar que o modelo linear pode ser ajustado aos dados observados. A análise de variância é efetuada para se calcular a razão $\mathrm{F}$ ( $F$ ratio), que é a estatística do teste. Se o valor observado da estatística $F\left(F_{o b s}\right)$ for maior ou igual ao valor crítico $\mathrm{F}_{\mathrm{c}}$, obtido a partir da distribuição $\mathrm{F}$ de Snedecor, com 1 e (n-2) graus de liberdade e um determinado nível de significância, então a hipótese de que o coeficiente angular da reta é nulo pode ser rejeitada. Na prática, se o nível de significância adotado para o teste for de $0,05 \%$, por exemplo, e $\mathrm{P}\left(\mathrm{F}_{\mathrm{obs}}>\mathrm{F}_{\mathrm{c}}\right)<<0,0005$, então a hipótese $\mathrm{H}_{0}$ pode ser rejeitada e o modelo linear considerado adequado para ajuste [33, 34].

Outra medida de interesse na análise de regressão é o coeficiente de determinação, denotado por $\mathrm{R}^{2}$ e calculado por meio da seguinte expressão:

$$
R^{2}=\frac{\text { SQReg }}{\text { SQTot }}
$$

indicando a proporção da variação de U que pode ser explicada pelo modelo de regressão. Pode-se interpretar o valor de $\mathrm{R}^{2}$ como sendo uma medida descritiva da qualidade do ajuste obtido. Pode-se usar, também, no lugar de $\mathrm{R}^{2}$, um coeficiente de determinação corrigido para graus de liberdade, o qual é dado por: 


$$
\bar{R}^{2}=R^{2}-\frac{1}{n-2}\left(1-R^{2}\right)
$$

Para completar o ajuste do modelo linear, devem ser calculados os intervalos de confiança para os estimadores dos parâmetros $\alpha$ e $\beta$ [33, 34]. Estes intervalos, considerando um nível de confiança de $\gamma$, são dados por meio das seguintes expressões:

$$
\begin{gathered}
I C(\alpha / \gamma)=\hat{\alpha} \pm t_{\gamma}(n-2) S_{e} \sqrt{\frac{\sum t_{i}^{2}}{n \sum\left(t_{i}-\bar{t}\right)^{2}}} \\
I C(\beta / \gamma)=\hat{\beta} \pm t_{\gamma}(n-2) S_{e} \sqrt{\frac{1}{\sum\left(t_{i}-\bar{t}\right)^{2}}} .
\end{gathered}
$$

O programa computacional OriginPro versão 8, desenvolvido pela OriginLab Corporation [35], foi usado na análise dos resultados deste estudo. Este programa, além de permitir a construção dos vários tipos de gráficos necessários para a análise dos resultados, também possui uma ferramenta de análise denominada Fit Linear, que faz o processamento dos dados e o ajuste pelo modelo linear.

\subsubsection{Análise das características morfológicas do catalisador usado nos conjuntos eletrodo-membrana-eletrodo (MEAs) após os testes de durabilidade de longa duração - caracterização por Microscopia Eletrônica de Transmissão (MET)}

Amostras da camada catalítica de um dos MEAs utilizados nos testes de durabilidade de longa duração foram analisadas por meio de microscopia eletrônica de transmissão para serem comparadas com amostras da camada catalítica de um MEA de controle (MEA novo, não usado nos testes de longa duração). Para aplicação desta técnica, foi usado um microscópio eletrônico de transmissão de $80 \mathrm{KeV}$ de potência, pertencente ao Instituto de Ciências Biomédicas (ICB) da USP.

Por meio desta análise, pode-se verificar a ocorrência de possíveis mudanças morfológicas, sobretudo no que diz respeito à aglomeração e ao crescimento das partículas de Pt em decorrência do tempo de operação. Para tanto, as partículas de Pt mostradas nas imagens obtidas pela microscopia são contadas e têm seus tamanhos medidos. A partir destes dados, são construídos histogramas com a distribuição dos tamanhos de partículas observados e calculados os tamanhos médios das partículas. 


\section{RESULTADOS E DISCUSSÕES}

\subsection{Resultados dos testes de durabilidade de longa duração com as células a combustível do tipo PEM}

Vários testes de durabilidade de longa duração com os MEAs produzidos no IPEN foram realizados no âmbito deste trabalho de pesquisa. Conforme mencionado na Seção 4.1.3, alguns parâmetros de operação das células a combustível precisaram ser ajustados de modo a otimizar o desempenho elétrico do MEA durante os testes. Assim, estes ajustes foram feitos, principalmente, nos fluxos dos gases reagentes $\left(\mathrm{H}_{2}\right.$ e $\left.\mathrm{O}_{2}\right)$ e na relação entre temperatura da célula a combustível, umidade relativa e ponto de orvalho dos gases. Sabese que o controle da umidificação do MEA é fundamental para o desempenho e a durabilidade deste dispositivo, uma vez que a falta de umidificação, além de ser deteriorante para a membrana, dificulta a condução protônica. Por outro lado, o excesso de umidificação pode causar vários problemas, tais como encharcamento, principalmente no lado do cátodo, e consequente bloqueio na difusão dos gases reagentes [16, 22, 23, 25].

Além disso, um procedimento muito importante incluído nas rotinas do programa computacional FuelWork, o qual é usado no controle das estações de teste, foi o de interrupção do experimento em caso de perda de alimentação dos gases reagentes. Se a carga dinâmica da estação de testes continuar drenando corrente elétrica da célula a combustível durante a ocorrência de uma falha na alimentação de um dos gases reagentes, uma corrente elétrica reversa será criada e ocorrerá uma corrosão severa do carbono suporte da camada catalítica do MEA e das placas de grafite da célula. Este tipo de falha pode causar danos irreversíveis na célula a combustível do tipo PEM [26]. Com o intuito de se evitar ou minimizar a corrosão do carbono, procurou-se também operar as células a combustível do tipo PEM em potenciais compreendidos entre 0,9 e $0,3 \mathrm{~V}$.

Para este trabalho, foram considerados os oito testes mais representativos dentre os dezoito que foram realizados no período de Junho de 2012 a Maio de 2013. Estes testes diferem entre si, basicamente, nos valores ajustados para a temperatura da célula a combustível e para o fluxo dos gases reagentes. Além disso, em dois destes testes foram incluídos procedimentos de ciclagem de potencial elétrico e de interrupções programadas (a cada 50 horas), visando a eliminação de fatores causadores de perdas reversíveis de desempenho da célula a combustível. Estas alterações são discutidas com mais detalhes ao longo da apresentação dos resultados. 
Na Tabela 2 são apresentados os parâmetros de preparação dos MEAs, os parâmetros de operação das células a combustível na estação de testes, assim como informações básicas a respeito do protocolo utilizado em cada teste. 
Tabela 2 - Parâmetros de preparação dos MEAs e parâmetros de operação das células a combustível durante os testes de durabilidade de longa duração.

\begin{tabular}{|c|c|c|c|c|c|c|c|c|}
\hline Parâmetro & Teste 1 & Teste 2 & Teste 3 & Teste 4 & Teste 5 & Teste 6 & Teste 7 & Teste 8 \\
\hline Carga de Pt no ânodo (mgPt.cm $\left.{ }^{-2}\right)$ & 0,42 & 0,42 & 0,42 & 0,47 & 0,47 & 0,47 & 0,47 & 0,47 \\
\hline Carga de Pt no cátodo (mgPt.cm $\left.{ }^{-2}\right)$ & 0,64 & 0,64 & 0,64 & 0,68 & 0,68 & 0,68 & 0,68 & 0,68 \\
\hline Fluxo de $\mathbf{H}_{2}\left(\mathrm{~mL}\right.$.min $\left.{ }^{-1}\right)$ & 220 & 220 & 220 & 220 & 300 & 300 & 400 & 300 \\
\hline Fluxo de $O_{2}\left(\mathrm{~mL} \cdot \mathrm{min}^{-1}\right)$ & 180 & 205 & 185 & 185 & 208 & 208 & 208 & 195 \\
\hline Pressão do $\mathrm{H}_{2}$ na célula (atm) & 1 & 1 & 1 & 1 & 1 & 1 & 1 & 1 \\
\hline Pressão do $\mathrm{O}_{2}$ na célula (atm) & 1 & 1 & 1 & 1 & 1 & 1 & 1 & 1 \\
\hline Temperatura da célula $\left({ }^{\circ} \mathbf{C}\right)$ & 70 & 75 & 75 & 75 & 75 & 75 & 75 & 75 \\
\hline Temperatura do $\mathrm{H}_{2}\left({ }^{\circ} \mathrm{C}\right)$ & 90 & 90 & 90 & 90 & 90 & 90 & 90 & 86 \\
\hline Temperatura do $\mathrm{O}_{2}\left({ }^{\circ} \mathrm{C}\right)$ & 80 & 80 & 80 & 80 & 80 & 80 & 80 & 80 \\
\hline Umidade relativa do $\mathrm{H}_{2}(\%)$ & 100 & 100 & 100 & 100 & 100 & 100 & 100 & 100 \\
\hline Umidade relativa do $\mathrm{O}_{2}(\%)$ & 100 & 100 & 100 & 100 & 100 & 100 & 100 & 100 \\
\hline $\begin{array}{l}\text { Principal característica do protocolo } \\
\text { utilizado }\end{array}$ & $\begin{array}{c}500 \text { horas } \\
\text { ininterruptas em } \\
\text { estado } \\
\text { estacionário }\end{array}$ & $\begin{array}{c}500 \text { horas } \\
\text { ininterruptas em } \\
\text { estado estacionário }\end{array}$ & $\begin{array}{l}\text { Operação em estado } \\
\text { estacionário com } \\
\text { ciclagens periódicas } \\
\text { a cada } 50 \text { horas + } \\
\text { curvas de } \\
\text { polarização } \\
\text { intermediárias }\end{array}$ & $\begin{array}{l}\text { Operação em estado } \\
\text { estacionário com } \\
\text { paradas } \\
\text { programadas de } 15 \\
\text { horas a cada } 50 \\
\text { horas + curvas de } \\
\text { polarização } \\
\text { intermediárias }\end{array}$ & $\begin{array}{c}500 \text { horas } \\
\text { ininterruptas em } \\
\text { estado } \\
\text { estacionário }\end{array}$ & $\begin{array}{c}500 \text { horas } \\
\text { ininterruptas em } \\
\text { estado } \\
\text { estacionário }\end{array}$ & $\begin{array}{l}500 \text { horas } \\
\text { ininterruptas } \\
\text { em estado } \\
\text { estacionário }\end{array}$ & $\begin{array}{c}500 \text { horas } \\
\text { ininterruptas em } \\
\text { estado estacionário }\end{array}$ \\
\hline
\end{tabular}




\subsubsection{Resultados do Teste 1}

No primeiro teste de durabilidade de longa duração de 500 horas em estado estacionário (Teste 1), verificou-se que, após cerca de 300 horas de operação, o potencial elétrico da célula a combustível diminuiu de maneira muito abrupta, conforme pode ser observado na Figura 8-a. No entanto, as curvas de polarização apresentadas na Figura 8b, obtidas imediatamente antes e após a operação de 500 horas, não indicam uma perda tão acentuada no desempenho do MEA.
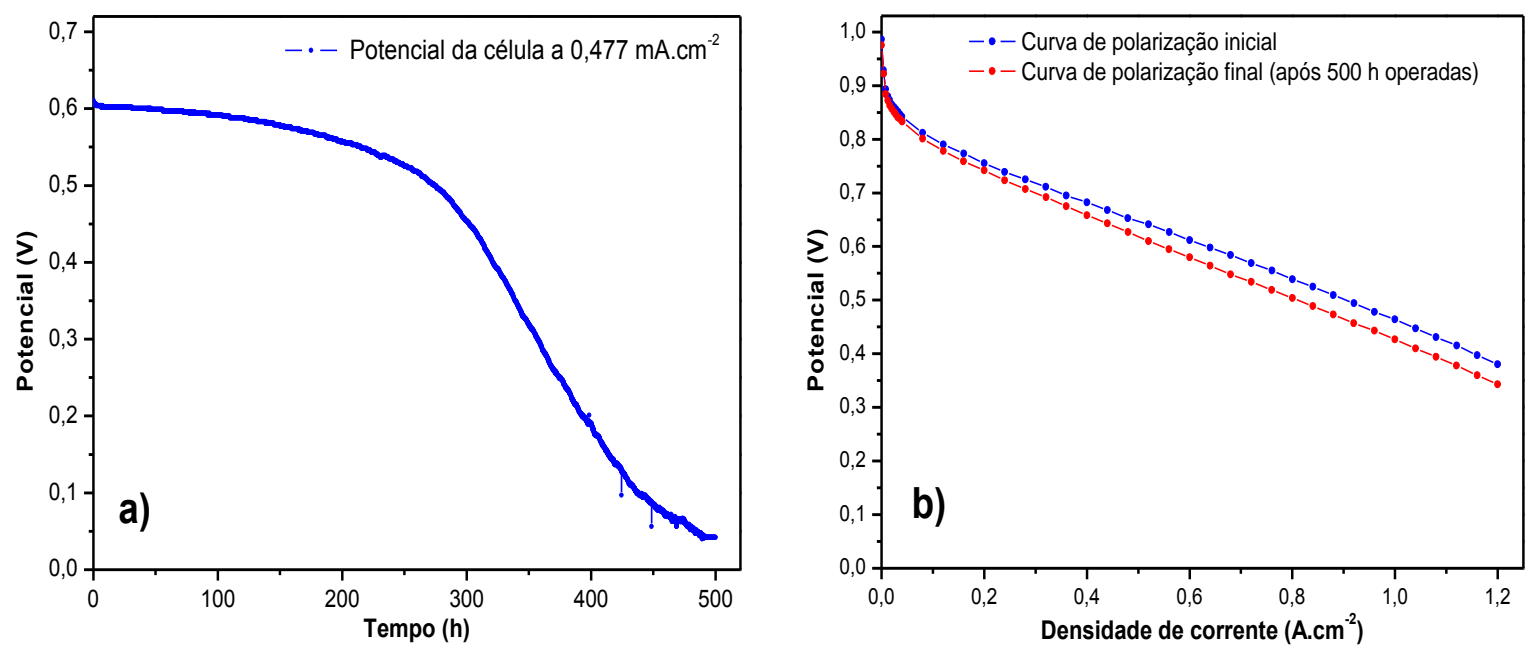

Figura 8 - a) comportamento do potencial elétrico ao longo do tempo do MEA utilizado no Teste 1 ; b) curvas de polarização extraídas antes e após o Teste 1 de 500 horas de duração.

De fato, após o término do teste, pode-se observar que os canais difusores de gás no ânodo do MEA estavam totalmente encharcados, conforme ilustra a Figura 9. O cátodo estava úmido, mas não apresentava este encharcamento. A causa mais provável para este fenômeno pode estar relacionada à configuração dos canais nas placas de grafite, os quais são responsáveis não apenas pela difusão dos gases, mas também pela drenagem do excesso de água. Uma configuração inadequada pode implicar num escoamento ineficiente, levando ao encharcamento no eletrodo. 


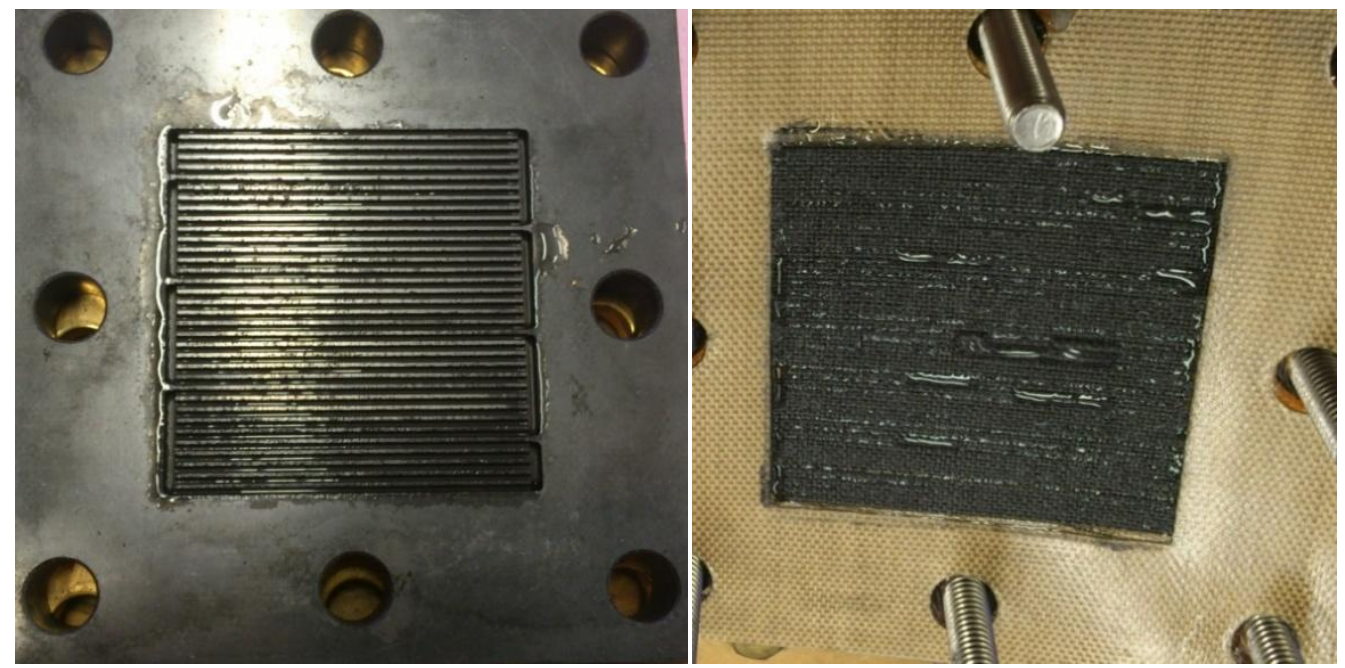

Figura 9 - Placa de grafite e ânodo encharcados após o Teste 1 de 500 horas.

Considerando que, para o Teste 1 , os parâmetros de temperatura foram ajustados baseando-se no melhor desempenho elétrico do MEA, ou seja, para se obter a maior densidade de potência para um determinado valor de potencial elétrico, concluiu-se que estes seriam os melhores parâmetros para a operação da célula a combustível do tipo PEM por longos períodos de operação. Todavia, o resultado empírico mostrou que isto não é uma condição necessária. Assim sendo, os testes seguintes foram realizados ajustando-se a temperatura da célula a combustível em $75^{\circ} \mathrm{C}$, no intuito de diminuir o encharcamento dos eletrodos.

\subsubsection{Resultados do Teste 2}

A princípio, o efeito do aumento da temperatura da célula a combustível para $75^{\circ} \mathrm{C}$ não foi muito significativo, pois, no Teste 2, o potencial elétrico da célula a combustível voltou a diminuir de modo mais acentuado após 300 horas de operação. No entanto, ocorreu um evento não programado após 400 horas de operação e o experimento foi interrompido devido à perda no suprimento de energia elétrica da rede externa para o IPEN. Quando a energia elétrica foi recuperada, verificou-se que o potencial elétrico da célula a combustível aumentou, com desempenho muito próximo ao do início do teste, conforme pode ser verificado na Figura 10-a. Ao mesmo tempo, analisando-se as curvas de polarização apresentadas na Figura 10-b, pode-se confirmar que a diferença no desempenho do MEA antes e após o experimento é muito pequena. É importante ressaltar que, após esta interrupção inesperada no experimento, a célula a combustível não foi aberta. Procedeu-se apenas o reinício do teste, realizando uma purga com nitrogênio, 
ciclagem de potencial elétrico, estabilização das condições de operação do sistema e construção de curvas de polarização.
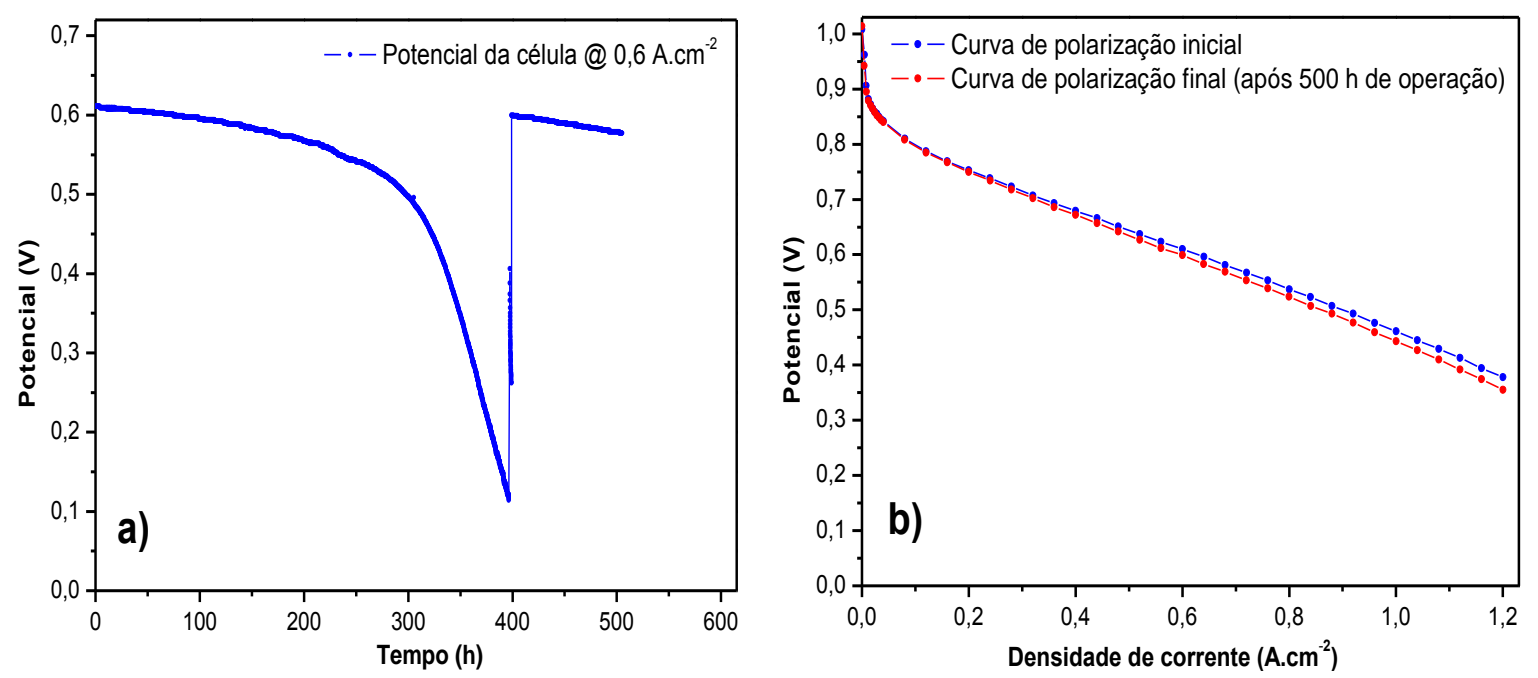

Figura 10 - a) comportamento do potencial elétrico ao longo do tempo do MEA utilizado no Teste 2 ; b) curvas de polarização extraídas antes e após o Teste 2 de 500 horas de duração.

\subsubsection{Resultados do Teste 3}

Nos Testes 1 e 2, um procedimento rápido de ciclagem do potencial elétrico da célula a combustível já havia sido incluído para ser executado imediatamente antes da obtenção da curva de polarização final. A ideia de se incluir esta ciclagem foi melhorar o desempenho do MEA na fase final do experimento, para a tomada da curva de polarização final. Assim, um terceiro teste foi realizado, no qual se optou por incluir este procedimento de ciclagem de potencial elétrico a cada 50 horas de operação da célula a combustível, como forma de se comprovar e minimizar uma eventual perda reversível do desempenho do MEA. Após cada ciclagem, era extraída uma curva de polarização e, depois de um curto período para estabilização do potencial da célula a combustível, retomava-se o período em estado estacionário.

Como pode ser observado na Figura 11-a, o resultado da inclusão deste procedimento de ciclagem do potencial elétrico da célula a combustível a cada 50 horas deixou mais aparente o comportamento reversível da perda de desempenho do MEA. É importante citar que os potenciais elétricos registrados durante os períodos de ciclagem não foram incluídos no gráfico da Figura 11-a. Assim, no gráfico construído a partir dos resultados do Teste 3 é possível verificar que a curva do potencial elétrico da célula a combustível em função do tempo apresenta uma característica de "dente de serra", 
representando as quedas e elevações do potencial elétrico antes e após o procedimento de ciclagem, respectivamente. Na Figura 11-b são apresentadas algumas curvas de polarização obtidas durante o Teste 3 .
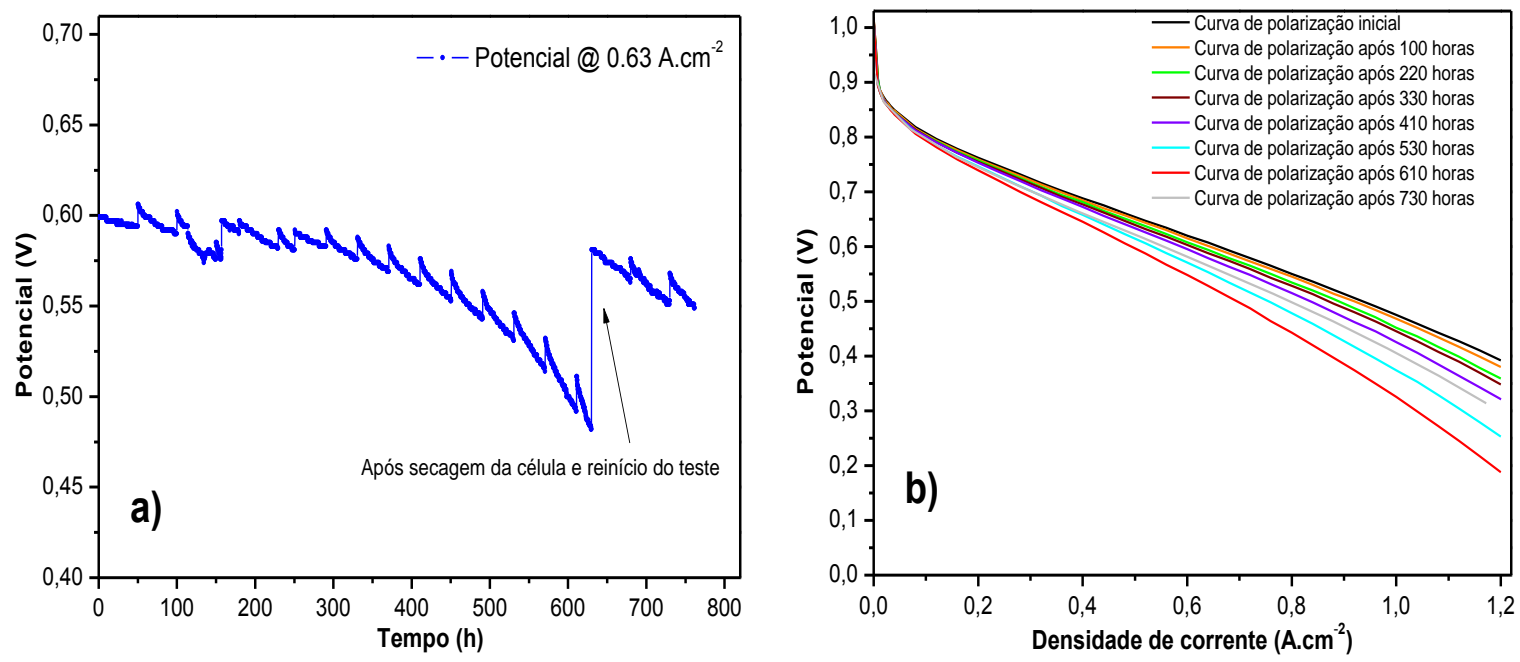

Figura 11 - a) comportamento do potencial elétrico ao longo do tempo do MEA utilizado no Teste 3, com ciclagens periódicas do potencial; b) curvas de polarização extraídas ao longo do Teste 3 .

Após cerca de 640 horas de operação, o Teste 3 foi interrompido para se efetuar a abertura da célula a combustível e secagem dos canais difusores e do MEA, os quais estavam encharcados. Após esta ação, o teste foi reiniciado, seguindo o mesmo protocolo de operação e verificou-se que o potencial elétrico da célula a combustível aumentou significativamente em relação ao valor observado logo antes da interrupção. Entretanto, pelas curvas de polarização mostradas na Figura 11-b, nota-se que a última curva registrada indica um desempenho do MEA inferior àquele do início do experimento. Embora a aplicação de ciclagens intercaladas na operação em estado estacionário tenha colaborado para mitigar o efeito reversível de perda de desempenho do MEA, sabe-se, da literatura, que este procedimento acelera a degradação de vários componentes da célula, principalmente da camada catalítica do eletrodo [16, 26, 27, 29]. 


\subsubsection{Resultados do Teste 4}

Após a verificação de que o desligamento seguido de um reinício da operação da célula a combustível pode ser mais eficiente na mitigação dos efeitos reversíveis de perda desempenho do MEA do que a inclusão de ciclagens periódicas, foi realizado um novo teste, Teste 4, considerando desligamentos e reinícios da operação da célula a combustível a cada 50 horas de operação do sistema. Este procedimento consistiu em paradas programadas do sistema, nas quais a carga dinâmica era desligada, o aquecimento dos gases reagentes e da célula a combustível eram desligados e o fluxo dos gases reagentes interrompido, seguindo-se com a purga com nitrogênio. $O$ sistema permanecia desligado por 15 horas e voltava a ser ligado, procedendo-se da mesma maneira que no início do experimento, ou seja, purga da célula com nitrogênio, aquecimento do sistema, ciclagens de potencial elétrico e estabilização dos parâmetros operacionais até o início do período estacionário.

Pela Figura 12-a, pode-se observar que a curva do potencial elétrico em função do tempo obtida no Teste 4 apresenta características semelhantes à do Teste 3, isto é, "dente de serra". Deve-se mencionar que, os potenciais elétricos registrados durante os períodos de pausa do Teste 4 não foram incluídos no gráfico da Figura 12-a e que, nestes períodos de pausa, a célula não foi aberta para retirada de excesso de água. No Teste 4, verificou-se que a cada reinício de um período estacionário, o potencial elétrico da célula a combustível apresentava um valor maior do que o registrado no final do ciclo imediatamente anterior. No entanto, quando comparada à curva do Teste 3 (Figura 11-a), observou-se que a curva do potencial elétrico em função do tempo obtida no Teste 4 apresentou um comportamento mais linear. Ao mesmo tempo, de acordo com a Figura 12-b, pode-se perceber a ocorrência de uma perda de desempenho do MEA usado no Teste 4 nas diversas curvas de polarização extraídas. Deste modo, pode-se perceber que o processo de acionamento/desligamento da célula a combustível também pode ser considerado um mecanismo de aceleração da degradação do MEA [26-29]. Portanto, quando o objetivo do teste é avaliar a taxa de variação do potencial elétrico do MEA ao longo do tempo em estado estacionário, conclui-se que estes períodos de paradas programadas ou ciclagens periódicas de potencial elétrico da célula a combustível não devem ser introduzidos. 

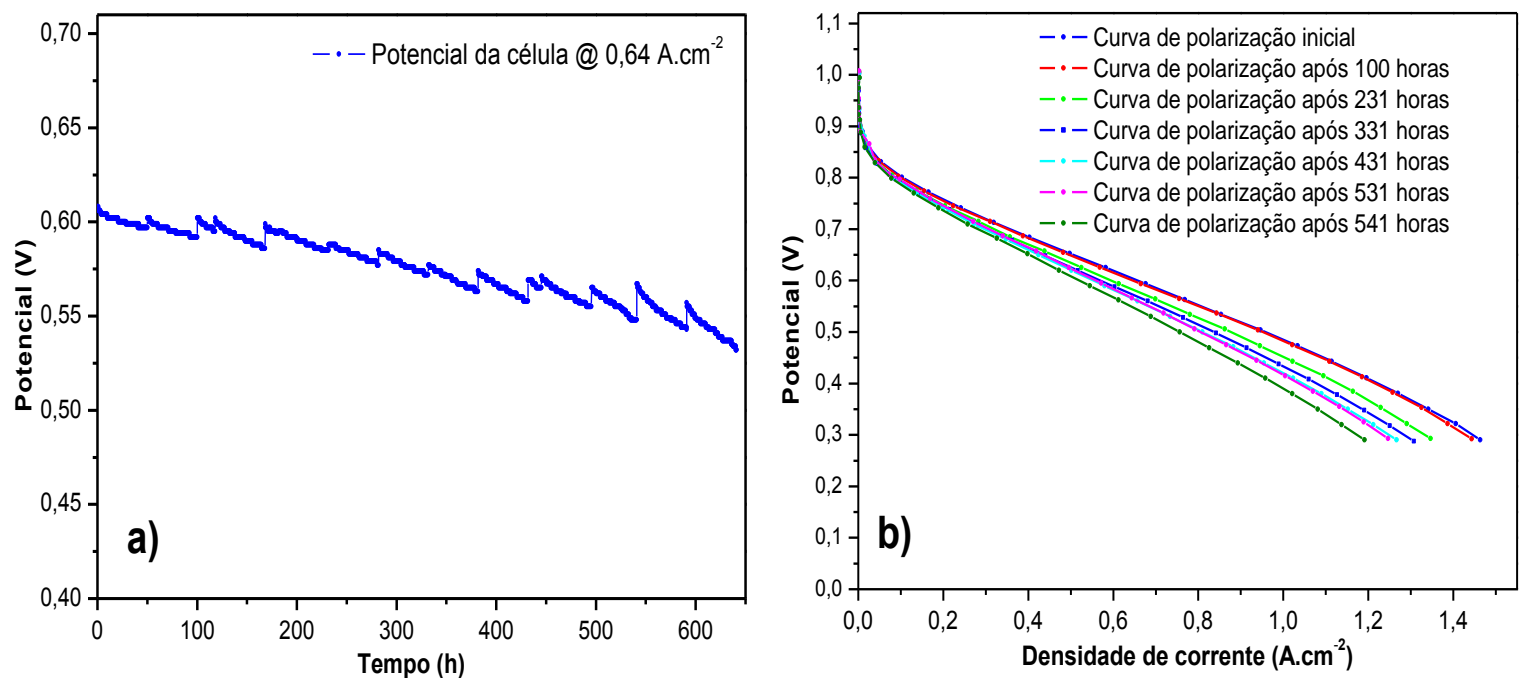

Figura 12 - a) comportamento do potencial elétrico ao longo do tempo do MEA utilizado no Teste 4, com paradas periódicas na operação do sistema; b) curvas de polarização extraídas ao longo do Teste 4.

\subsubsection{Resultados dos Testes 5 e 6}

Os Testes 5 e 6 seguiram o mesmo protocolo dos Testes 1 e 2, com exceção dos fluxos dos gases reagentes que foram ajustados para valores mais altos. Foi observado que, com essa alteração, o acúmulo de água na célula a combustível diminuiu, mas não deixou de ocorrer. Os pontos correspondentes ao potencial elétrico das células a combustível em função do tempo de operação durante os Testes 5 e 6 são apresentados nas Figuras 13-a e 14-a, respectivamente.
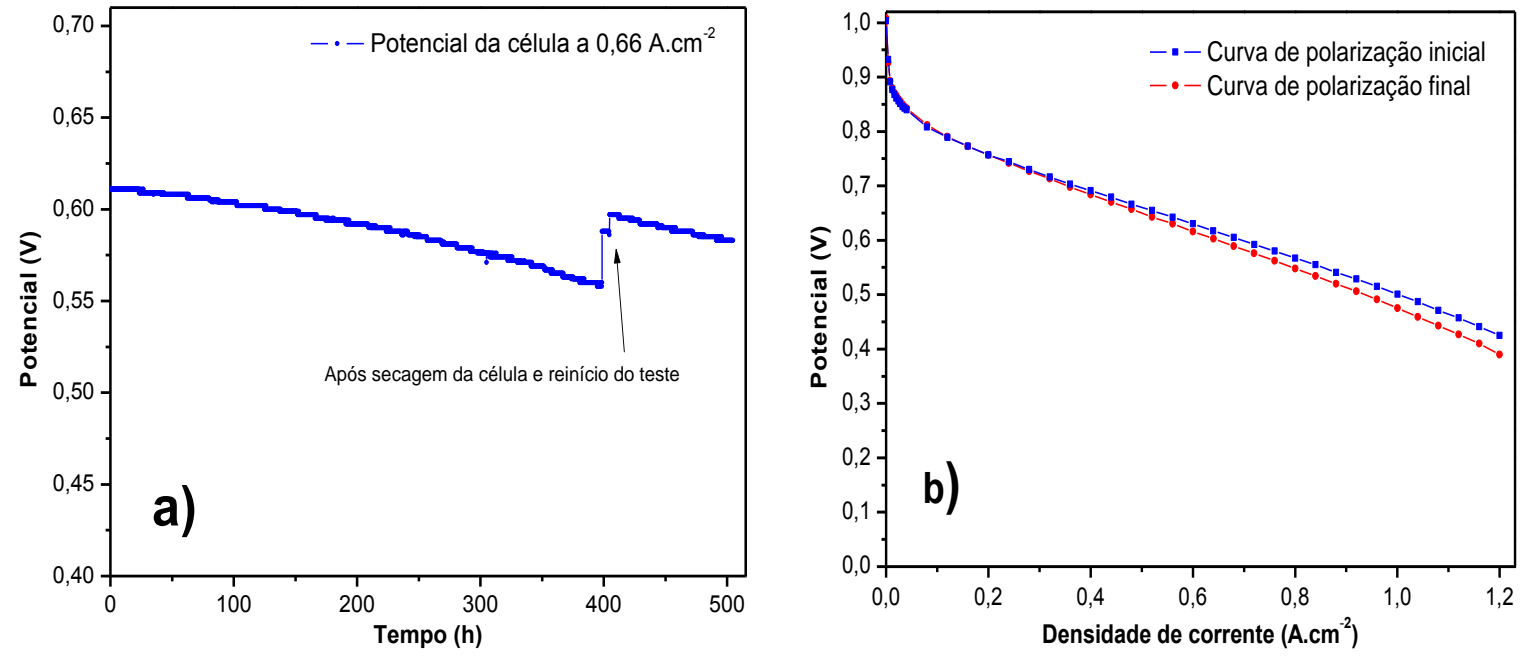

Figura 13 - a) comportamento do potencial elétrico ao longo do tempo do MEA utilizado no Teste 5; b) curvas de polarização extraídas no Teste 5, antes e após 500 horas de operação. 
Em ambos os Testes, 5 e 6, ocorreram algumas interrupções não programadas devido a perda de energia elétrica da rede externa para o IPEN. Após estas interrupções, as células a combustível foram abertas, secadas e os testes reiniciados. Pode-se perceber que, nos dois testes, após um reinício de operação do sistema, o potencial elétrico da célula a combustível atingia um valor mais alto do que aquele observado imediatamente antes da interrupção. Estas evidências indicam a presença de fatores que, ao longo do tempo, ocasionam perdas de desempenho dos MEAs e que estas perdas podem ser reversíveis. Além disso, este fato pode ser confirmado analisando-se as curvas de polarização obtidas nos Testes 5 e 6, representadas nas Figuras 13-b e 14-b, respectivamente. As diferenças entre as curvas de polarização construídas antes e depois de uma interrupção da operação da célula a combustível não são significativas.
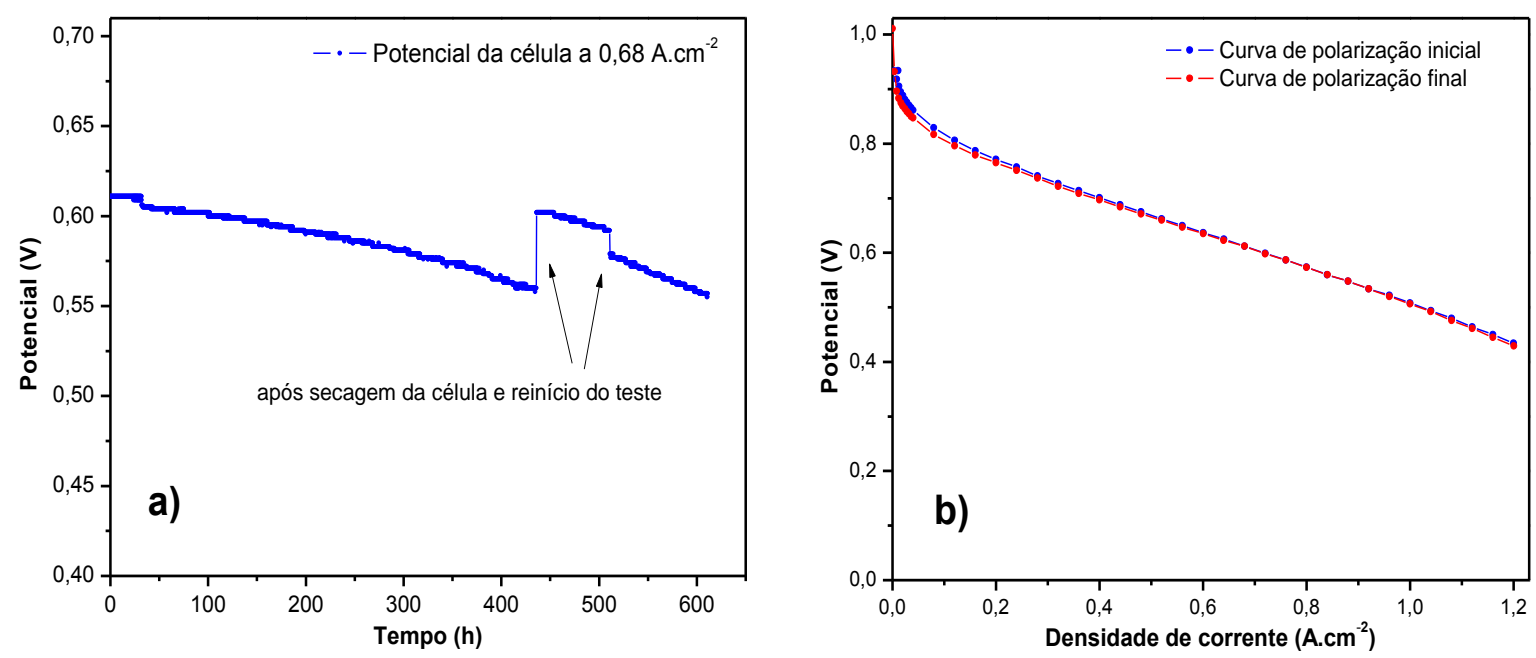

Figura 14 - a) comportamento do potencial elétrico ao longo do tempo do MEA utilizado no Teste 6; b) curvas de polarização extraídas no Teste 6 , antes e após 600 horas de operação.

\subsubsection{Resultados do Teste 7}

Como os Testes 5 e 6 apresentaram melhores resultados do que os testes anteriores, principalmente devido ao aumento do fluxo de $\mathrm{H}_{2}$, houve então uma motivação para se avaliar o efeito da aplicação de um fluxo ainda maior durante a operação da célula a combustível. Assim, no Teste 7, aplicou-se o mesmo protocolo dos Testes 5 e 6, porém com fluxo de $\mathrm{H}_{2}$ ajustado para $400 \mathrm{ml} \cdot \mathrm{min}^{-1}$, buscando, assim, um aprimoramento no protocolo de testes. No entanto, como pode ser observado na Figura 15-a, embora muitas interrupções imprevistas tenham ocorrido durante a execução do teste, a célula a combustível se comportou de maneira muito similar aos testes anteriores, ou seja, com 
perda acentuada, porém reversível, do potencial elétrico ao longo do tempo. As curvas de polarização dispostas na Figura 15-b comprovam a reversibilidade da perda de desempenho. Então, conclui-se que o desempenho da célula a combustível e o controle da reversibilidade da perda de desempenho do MEA não são, necessariamente, proporcionais ao fluxo de $\mathrm{H}_{2}$, podendo existir, portanto, um limiar ótimo para este parâmetro. De fato, quanto maior o fluxo de gás entrando pelos canais difusores, maior a quantidade de água carregada para dentro da célula a combustível. Por outro lado, um fluxo muito baixo pode também gerar acúmulo de água nos canais difusores, uma vez que este fluxo pode ser insuficiente para purgar a água trazida pelos gases e que se condensa nos canais ou a água produzida pela reação eletroquímica no cátodo da célula a combustível [16].
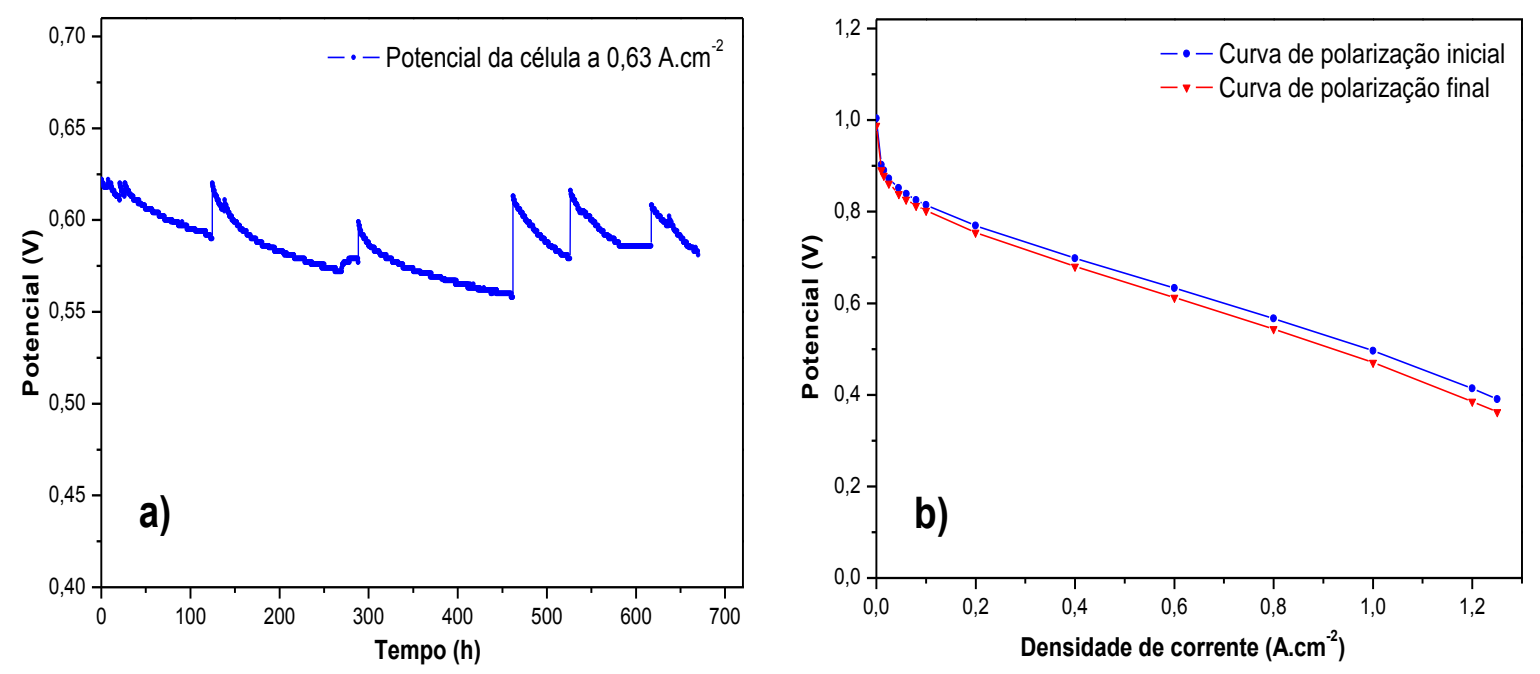

Figura 15 - a) comportamento do potencial elétrico ao longo do tempo do MEA utilizado no Teste 7; b) curvas de polarização extraídas no Teste 7, antes e após 670 horas de operação.

\subsubsection{Resultados do Teste 8}

Os testes realizados no laboratório apresentaram evidências de que o acúmulo de água nos canais difusores das placas de grafite é um grande impeditivo para a realização de testes de longa duração. Pode-se dizer que, este problema, além de causar perdas de desempenho reversíveis, contribui, também, para a degradação irreversível do MEA em operação [16]. Uma das maneiras de se controlar a quantidade de água que é condensada dentro dos canais difusores da placa monopolar da célula a combustível é fazer um ajuste na umidade relativa dos gases nos canais. Isto pode ser feito, principalmente, por meio da diferença entre a temperatura do gás umidificado e a temperatura da célula a combustível, assumindo que o gás é injetado na célula com $100 \%$ de umidade relativa. Assim, no Teste 
8 , utilizou-se o mesmo protocolo dos Testes 5 e 6 , alterando-se apenas a temperatura do $\mathrm{H}_{2}$, a qual foi ajustada para $86^{\circ} \mathrm{C}$. Além disso, na metade do período de operação em estado estacionário, foi inserida uma rotina para elaboração de uma curva de polarização. Os pontos observados do potencial elétrico da célula a combustível em função do tempo são apresentados na Figura 16-a.
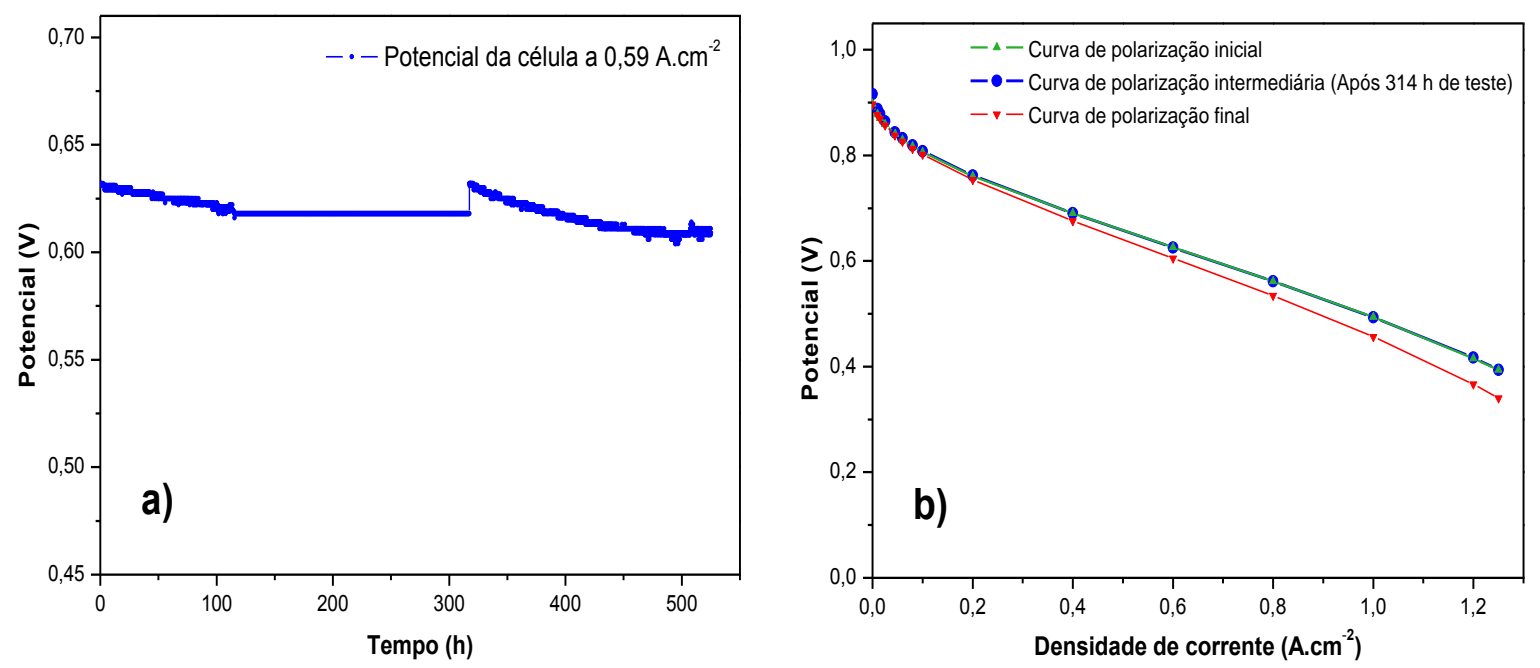

Figura 16 - a) comportamento do potencial elétrico ao longo do tempo do MEA utilizado no Teste 8 ; b) curvas de polarização extraídas no Teste 8 , antes e após 670 horas de operação.

A mudança na temperatura de entrada do $\mathrm{H}_{2}$ na célula a combustível, embora tenha contribuído para amenizar os efeitos reversíveis de perda de desempenho deste dispositivo, ainda não é suficiente para eliminar completamente estes fatores. Este fato pode ser observado pelo gráfico da Figura 16-a, pois após a obtenção da curva de polarização intermediária e o reinício do período estacionário, os valores obtidos para o potencial elétrico aumentaram em relação aos valores registrados imediatamente antes desta curva de polarização. Analisando-se as curvas de polarização da Figura 16-b, pode-se verificar que a perda de desempenho observada por meio destas curvas aparenta ser menor do que os resultados mostrados na Figura 16-a.

Durante a execução deste teste ocorreu uma interrupção não programada devido à perda do fornecimento de energia elétrica da rede externa para o IPEN. Além disso, no período compreendido entre 110 e 317 horas do teste, ocorreu algum tipo de pane no programa computacional Fuelwork, prejudicando a aquisição de dados do teste neste período, conforme pode ser observado na Figura 16-a. 


\subsection{Análise dos resultados obtidos nos testes de durabilidade de longa duração com as células a combustível do tipo PEM produzidas no IPEN}

Com base na metodologia proposta na Seção 4.2.1, foi efetuada a análise estatística dos dados obtidos nos testes de durabilidade de longa duração com as células a combustível do tipo PEM produzidas no IPEN. O objetivo desta análise foi obter estimativas da taxa de variação do potencial elétrico da célula a combustível ao longo do tempo, considerando a operação por um período longo em estado estacionário. Estas estimativas foram dadas em termos dos valores médios observados nos testes e dos erros associados a estas médias.

Para esta análise estatística, foram selecionados os testes em que as células a combustível puderam operar o maior tempo possível em estado estacionário, que são os Testes 1, 5, 6 e 8 e que cujos resultados foram avaliados qualitativamente na seção anterior, Seção 5.1 .

Na Tabela 3 é apresentado um resumo dos resultados quantitativos obtidos nos testes de durabilidade de longa duração selecionados para esta análise.

Tabela 3 - Resumo dos resultados obtidos nos testes de durabilidade de longa duração com as células a combustível do tipo PEM produzidas no IPEN.

\begin{tabular}{|c|c|c|c|c|}
\hline & Teste 1 & Teste 5 & Teste 6 & Teste 8 \\
\hline $\begin{array}{l}\text { Tempo total de teste em estado } \\
\text { estacionário (horas) }\end{array}$ & 267 & 397 & 435 & 207 \\
\hline No. de pontos amostrais registrados & 16011 & 3970 & 4355 & 2070 \\
\hline $\begin{array}{l}\text { Média da densidade de corrente da célula } \\
\text { durante o teste }\left({\left.\mathrm{A} . \mathrm{cm}^{-2}\right)}^{-2}\right.\end{array}$ & 0,66 & 0,65 & 0,68 & 0,59 \\
\hline $\begin{array}{l}\text { Média do potencial elétrico da célula } \\
\text { durante o teste }(\mathrm{mV})\end{array}$ & 0,574 & 0,589 & 0,588 & 0,615 \\
\hline \multicolumn{5}{|l|}{ Perda de potencial elétrico da célula ao } \\
\hline final do teste $=\frac{U_{\text {final }}-U_{\text {inicial }}}{U_{\text {inicial }}} \times 100 \%$ & 16,7 & 4,5 & 3,76 & 3,4 \\
\hline $\begin{array}{l}\text { Média da densidade de potência da célula } \\
\text { durante o teste }\left({\left.\mathrm{W} . \mathrm{cm}^{-2}\right)}^{-}\right.\end{array}$ & 0,38 & 0,38 & 0,39 & 0,36 \\
\hline \multicolumn{5}{|l|}{ Perda da densidade de potência da célula } \\
\hline ao final do teste $=\frac{p_{\text {final }}-p_{\text {inicial }}}{p_{\text {inicial }}} \times 100 \%$ & 16,7 & 4,5 & 3,76 & 3,4 \\
\hline
\end{tabular}


Para o cálculo das estimativas da taxa de variação (queda ou aumento), em função do tempo, do potencial elétrico das células a combustível do tipo PEM foi aplicada a análise de regressão linear ao dados obtidos nos Testes 1, 5, 6 e 8. Em todos os casos selecionados, foi observado que ocorre uma queda no valor do potencial elétrico da célula a combustível ao longo do tempo. As estimativas da taxa de queda do potencial elétrico e os erros associados a estas medidas são dados em $\mu \mathrm{V} \cdot \mathrm{h}^{-1}$ (microvolts por hora).

A estimativa da taxa de queda do potencial elétrico da célula a combustível fornece uma medida global de quanto o MEA, reversível ou irreversivelmente, perde seu desempenho ao longo do tempo. O desvio padrão associado é uma medida que leva em conta a variação dos dados amostrais em relação ao valor médio estimado para esta taxa de queda do potencial elétrico. Se o comportamento do potencial elétrico da célula ao longo do tempo não puder ser ajustado por meio de uma reta, faz-se necessário aplicar técnicas de regressão não-linear ou métodos estatísticos mais sofisticados para ajuste de modelos $[33,34]$.

Na Figura 17, do item a ao item d, pode-se verificar o resultado do ajuste linear nos gráficos obtidos com os testes de durabilidade selecionados para esta análise. 

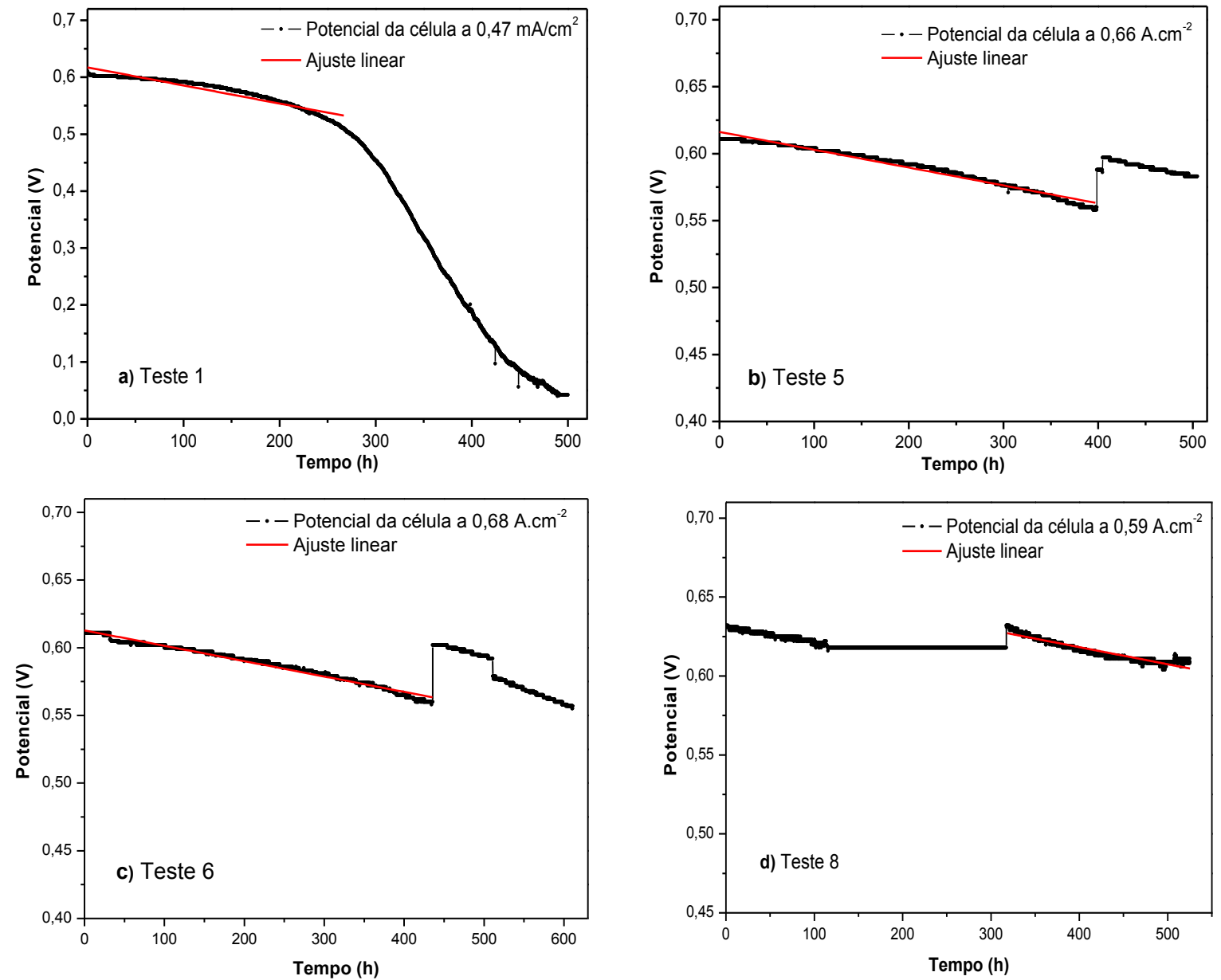

Figura 17 - Modelos de regressão linear ajustados aos dados obtidos nos testes de durabilidade de longa duração com as células a combustível do tipo PEM - a) Teste 1; b) Teste 5; c) Teste 6; e d) Teste 8.

Conforme apresentado na Tabela 4, os menores valores de taxa de queda de potencial elétrico alcançados nos experimentos realizados neste trabalho estão em torno de $110 \mu \mathrm{V} \cdot \mathrm{h}^{-1}$. Na literatura especializada, os valores encontrados, bem como as metas propostas para células a combustível do tipo PEM usadas em aplicações estacionárias estão em torno de 2-10 $\mu \mathrm{V} \cdot \mathrm{h}^{-1}[19,22,24]$. No entanto, de acordo com a análise dos testes aqui apresentados, os valores de perda de desempenho obtidos neste estudo se devem, em grande parte, às perdas de desempenho reversíveis, principalmente pelo acúmulo de água nos canais difusores das placas de grafite. Assim, pressupõe-se que os valores reais de perda de desempenho dos MEAs estudados sejam bem inferiores aos obtidos. 
Tabela 4 - Estimativas da taxa de queda do potencial elétrico e do desvio padrão associado para as células a combustível do tipo PEM nos Testes 1, 5, 6 e 8.

\begin{tabular}{ccc}
\hline Teste & $\begin{array}{c}\text { Taxa de queda do potencial } \\
\text { elétrico }\left(\boldsymbol{\mu V} \mathbf{V} \mathbf{h}^{-\mathbf{1}}\right)\end{array}$ & Desvio padrão $\left(\boldsymbol{\mu V} \cdot \mathbf{h}^{-1}\right)$ \\
\hline Teste 1 & 318,15 & 0,79 \\
Teste 5 & 133,32 & 0,32 \\
Teste 6 & 113,56 & 0,23 \\
Teste 8 & 108,09 & 0,78 \\
\hline
\end{tabular}

Nas Tabelas 5, 6, 7 e 8 são apresentadas as análises de variância (ANOVA) efetuadas para a avaliação da adequação dos modelos de regressão linear ajustados aos dados. Além das tabelas da ANOVA, são apresentados, na Tabela 9, os coeficientes de determinação calculados para cada modelo de regressão linear ajustado aos dados dos Testes $1,5,6$ e 8 .

Tabela 5 - ANOVA para o modelo de regressão linear ajustado aos dados do Teste 1.

\begin{tabular}{c|c|c|c|c|c}
\hline $\begin{array}{c}\text { Fonte de } \\
\text { variação }\end{array}$ & $\begin{array}{c}\text { Graus de } \\
\text { liberdade } \\
\text { (g.l.) }\end{array}$ & $\begin{array}{c}\text { Soma de } \\
\text { Quadrados } \\
(\text { SQ) }\end{array}$ & $\begin{array}{c}\text { Quadrado Médio } \\
(\mathbf{Q M})\end{array}$ & $\begin{array}{c}\text { Estatística } \\
\mathbf{F}\end{array}$ & $\begin{array}{c}\text { Prob }\left(\mathbf{F}_{\text {obs }}>\right. \\
\left.\mathbf{F}_{\mathbf{c}}\right)\end{array}$ \\
\hline Regressão & 1 & 9,61688 & 9,61688 & 162390,70744 & 0 \\
Resíduo & 16009 & 0,94806 & $5,92206.10^{-5}$ & & \\
\hline Total & 16010 & 10,56494 & $6,5989.10^{-4}$ & & \\
\hline
\end{tabular}

Tabela 6 - ANOVA para o modelo de regressão linear ajustado aos dados do Teste 5.

\begin{tabular}{c|c|c|c|c|c}
\hline $\begin{array}{c}\text { Fonte de } \\
\text { variação }\end{array}$ & $\begin{array}{c}\text { Graus de } \\
\text { liberdade } \\
\text { (g.l.) }\end{array}$ & $\begin{array}{c}\text { Soma de } \\
\text { Quadrados } \\
(\mathbf{S Q})\end{array}$ & $\begin{array}{c}\text { Quadrado Médio } \\
(\mathbf{Q M})\end{array}$ & $\begin{array}{c}\text { Estatística } \\
\mathbf{F}\end{array}$ & $\begin{array}{c}\text { Prob }\left(\mathbf{F}_{\text {obs }}>\right. \\
\left.\mathbf{F}_{\mathbf{c}}\right)\end{array}$ \\
\hline Regressão & 1 & 0,92689 & 0,92689 & 175975,48221 & 0 \\
Resíduo & 3968 & 0,0209 & $5,26713.10^{-6}$ & & \\
\hline Total & 3969 & 0,94779 & $2,3882.10^{-4}$ & & \\
\hline
\end{tabular}


Tabela 7 - ANOVA para o modelo de regressão linear ajustado aos dados do Teste 6.

\begin{tabular}{c|c|c|c|c|c}
\hline $\begin{array}{c}\text { Fonte de } \\
\text { variação }\end{array}$ & $\begin{array}{c}\text { Graus de } \\
\text { liberdade } \\
(\text { g.l. })\end{array}$ & $\begin{array}{c}\text { Soma de } \\
\text { Quadrados } \\
(\mathbf{S Q})\end{array}$ & $\begin{array}{c}\text { Quadrado Médio } \\
(\mathbf{Q M})\end{array}$ & $\begin{array}{c}\text { Estatística } \\
\mathbf{F}\end{array}$ & $\begin{array}{c}\text { Prob }\left(\mathbf{F}_{\text {obs }}>\right. \\
\left.\mathbf{F}_{\mathbf{c}}\right)\end{array}$ \\
\hline Regressão & 1 & 0,88777 & 0,88777 & 237189,42381 & 0 \\
Resíduo & 4353 & 0,01629 & $3,74289.10^{-6}$ & & \\
\hline Total & 4354 & 0,90407 & $2,0764.10^{-4}$ & & \\
\hline
\end{tabular}

Tabela 8 - ANOVA para o modelo de regressão linear ajustado aos dados do Teste 8.

\begin{tabular}{c|c|c|c|c|c}
\hline $\begin{array}{c}\text { Fonte de } \\
\text { variação }\end{array}$ & $\begin{array}{c}\text { Graus de } \\
\text { liberdade } \\
(\text { g.l. })\end{array}$ & $\begin{array}{c}\text { Soma de } \\
\text { Quadrados } \\
(\mathbf{S Q})\end{array}$ & $\begin{array}{c}\text { Quadrado Médio } \\
(\mathbf{Q M})\end{array}$ & $\begin{array}{c}\text { Estatística } \\
\mathbf{F}\end{array}$ & $\begin{array}{c}\text { Prob }\left(\mathbf{F}_{\text {obs }}>\right. \\
\left.\mathbf{F}_{\mathbf{c}}\right)\end{array}$ \\
\hline Regressão & 1 & 0,08637 & 0,08637 & 18388,43838 & 0 \\
Resíduo & 2068 & 0,00971 & $4,69704.10^{-6}$ & & \\
\hline Total & 2069 & 0,09608 & $4,64.10^{-5}$ & & \\
\hline
\end{tabular}

Tabela 9 - Coeficientes de determinação calculados após os ajustes dos modelos lineares aos dados dos testes de durabilidade de longa duração.

\begin{tabular}{cccc}
\hline & $\begin{array}{c}\text { Coeficiente de } \\
\text { determinação R }\end{array}$ & $\begin{array}{c}\text { Graus de liberdade } \\
\text { (g.l.) }\end{array}$ & $\begin{array}{c}\text { Coeficiente de determinação } \\
\text { ajustado } \bar{R}^{2}\end{array}$ \\
\hline Teste 1 & 0,91026 & 16009 & 0,91026 \\
Teste 5 & 0,97794 & 3968 & 0,97794 \\
Teste 6 & 0,98197 & 4353 & 0,98197 \\
Teste 8 & 0,89886 & 2068 & 0,89886 \\
\hline
\end{tabular}

Os valores de $\mathrm{R}^{2}$ podem ser usados como indicadores da qualidade do ajuste do modelo estatístico empregado. Conforme indicado na Tabela 9, em todos os casos estudados, o modelo linear mostrou-se adequado para o ajuste.

Finalmente, os modelos lineares ajustados para cada caso e os intervalos de confiança construídos para os estimadores de $\alpha$ e $\beta$ são apresentados na Tabela 10. 
Tabela 10 - Resumo dos modelos lineares ajustados para os Testes 1, 5, 6 e 7 e intervalos de confiança para os estimadores dos parâmetros do modelo.

\begin{tabular}{cccc}
\hline Modelo & $\begin{array}{c}\text { Intervalo de confiança } \\
\text { de 95\% para } \boldsymbol{\alpha}\end{array}$ & $\begin{array}{c}\text { Intervalo de confiança } \\
\text { de 95\% para } \boldsymbol{\beta}\end{array}$ \\
\hline Teste 1 & $0,6174-3,1815.10^{-4} \mathrm{t}$ & {$[0,6171 ; 0,6176]$} & {$\left[-3,17.10^{-4} ;-3,20.10^{-4}\right]$} \\
Teste 5 & $0,6162-1,3332.10^{-4} \mathrm{t}$ & {$[0,6161 ; 0,6164]$} & {$\left[-1,33.10^{-4} ;-1,34.10^{-4}\right]$} \\
Teste 6 & $0,6128-1,1356.10^{-4} \mathrm{t}$ & {$[0,6127 ; 0,6129]$} & {$\left[-1,13.10^{-4} ;-1,14.10^{-4}\right]$} \\
Teste 8 & $0,6615-1,0809.10^{-4} \mathrm{t}$ & {$[0,6608 ; 0,6621]$} & {$\left[-1,07.10^{-4} ;-1,10.10^{-4}\right]$} \\
\hline
\end{tabular}

\subsection{Caracterização dos MEAs por Microscopia Eletrônica de Transmissão (MET)}

Amostras da camada catalítica do MEA utilizado no Teste 5 foram analisadas por meio de MET para serem comparadas com amostras da camada catalítica de um MEA de controle (MEA novo, não usado nos testes de longa duração). As micrografias e os histogramas com a distribuição dos tamanhos de partículas de Pt, incluindo os tamanhos médios calculados, são apresentados na Figura 18.

$\mathrm{Na}$ análise das amostras do MEA utilizado no Teste 5, as médias de tamanho de partículas de Pt são maiores do que as médias calculadas a partir das amostras do MEA de controle. Enquanto o tamanho médio das partículas de Pt do MEA de controle foi de $4 \mathrm{~nm}$, o tamanho médio das partículas de Pt do MEA do Teste 5 ficou em torno de 6 a $7 \mathrm{~nm}$. Isto pode ser uma evidência de que, em decorrência do tempo de operação, as nanopartículas de Pt se aglomeraram, formando partículas de maior diâmetro. No entanto, a perda de desempenho da célula a combustível no Teste 5 não foi tão acentuada. Esta comparação contradiz um resultado descrito em $[11,16]$, no qual espera-se que uma aglomeração maior da partículas de Pt no catalisador do MEA possa levar a uma perda de desempenho irreversível da célula a combustível do tipo PEM. 

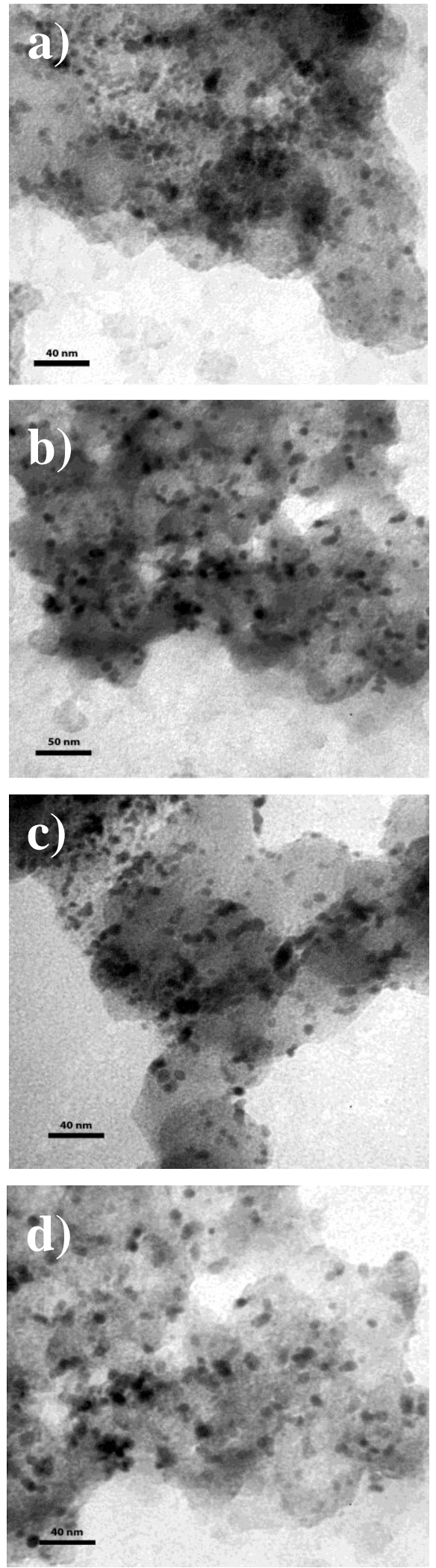
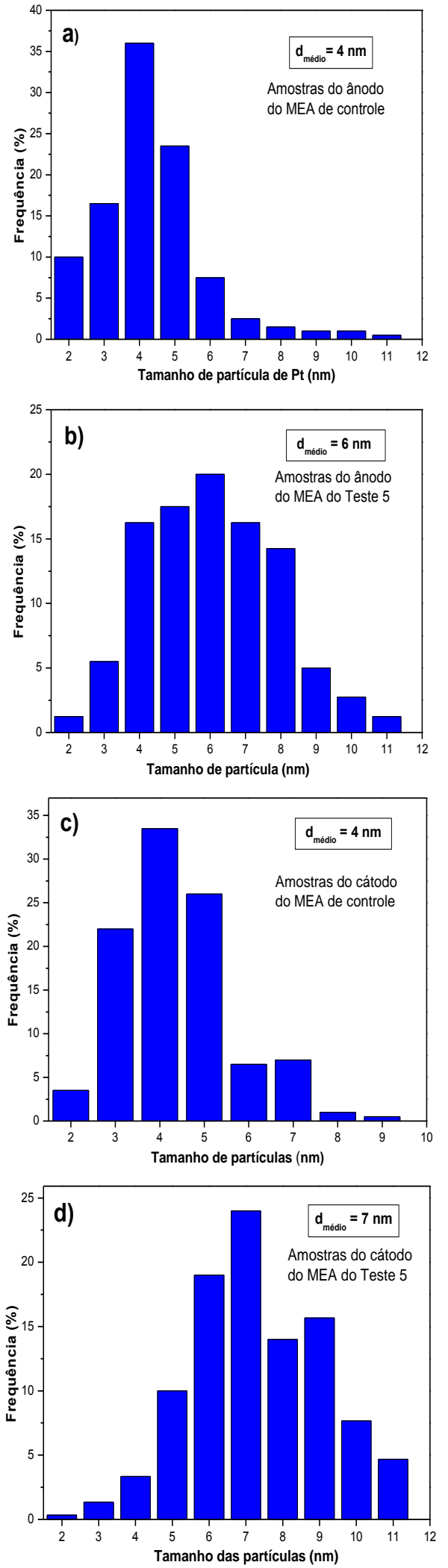

Figura 18 - Micrografias feitas por MET e histogramas construídos com base em amostras do MEA usado no Teste 5 e amostras de um MEA de controle: a) imagem de MET e histograma do ânodo do MEA de controle; b) imagem de MET e histograma do ânodo do MEA do Teste 5; c) imagem de MET e histograma do cátodo do MEA de controle; d) imagem de MET e histograma do cátodo do MEA do Teste 5. 


\section{CONCLUSÕES}

Os estudos realizados neste trabalho são de grande importância para a pesquisa e desenvolvimento de células a combustível do tipo PEM e podem ser considerados satisfatórios, pois além de serem resultado de um trabalho pioneiro no IPEN e no Brasil, estes estudos serviram como base para a elucidação das principais características, dificuldades e desafios na execução de testes de durabilidade.

Os ajustes nos parâmetros de operação do protocolo de TDLD, embora tenham levado a uma melhoria na qualidade dos resultados obtidos, ainda não podem ser considerados ideais, visto que ainda há evidências de existirem fatores que causam perdas de desempenho reversíveis em algumas condições operacionais. A partir desses resultados pôde-se concluir também que os parâmetros de operação considerados ótimos para testes de curta duração não são, necessariamente, os mais adequados para estudos de durabilidade de longa duração.

Ficou constatado que fenômenos que levam a uma perda reversível no desempenho das células a combustível do tipo PEM dificultam a elucidação dos mecanismos de degradação e uma quantificação precisa das taxas de perda de desempenho dos MEAs que podem ser atribuídas a fenômenos irreversíveis. Neste sentido, foi observado que os principais efeitos que causam perdas de desempenho reversíveis são o acúmulo de água na camada difusora dos MEAs e nos canais difusores de gás das placas de grafite. Estes efeitos podem distorcer os valores calculados para taxa global de perda de desempenho, pois a componente relativa às perdas reversíveis acaba sendo incluída neste cálculo.

$\mathrm{Na}$ análise estatística dos dados obtidos com os testes de durabilidade com as células a combustível operando em estado estacionário pôde-se verificar, por meio da análise de variância e dos testes de $\mathrm{R}^{2}$, que os modelos lineares se ajustaram com bastante precisão aos dados dos testes. As estimativas da taxa de variação do potencial elétrico em função do tempo foram calculadas entre 318,15 e $108,19 \mu \mathrm{V} \cdot \mathrm{h}^{-1}$. Estas estimativas foram dadas em termos dos valores médios observados nos testes e os erros associados a estas médias são 0,79 e $0,78 \mu \mathrm{V} \cdot \mathrm{h}^{-1}$, respectivamente. Estes valores, embora distantes daqueles propostos como metas (entre 2 - $10 \mu \mathrm{V} \cdot \mathrm{h}^{-1}$ ), podem ser considerados satisfatórios, uma vez que se devem em grande parte às perdas de desempenho reversíveis. 
Quando se deseja avaliar a durabilidade dos MEAs com a célula a combustível operando em estado estacionário, o ideal é evitar que durante os testes ocorram eventos que acelerem a degradação destes dispositivos. No entanto, se durante a operação real da célula a combustível é possível que ocorram eventos não-programados similares aos observados durante os testes, então alguns procedimentos que simulem estes eventos podem ser incluídos nos protocolos de TDLD. Neste caso, o desafio maior continuará sendo o de separar as componentes de perdas reversíveis e irreversíveis para se efetuar uma avaliação mais precisa do desempenho global dos MEAs, considerando a célula a combustível do tipo PEM operando por longos períodos de tempo.

As micrografias realizadas por Microscopia Eletrônica de Transmissão (MET), que serviram como técnica complementar no estudo de durabilidade, mostraram uma tendência de aumento no tamanho médio das partículas de Pt em decorrência do tempo de operação dos MEAs, mas que não implicou numa queda significativa do desempenho das células a combustível do tipo PEM testadas.

Finalmente, conclui-se que o protocolo de TDLD elaborado pode ser considerado satisfatório, pois embora ainda careça de alguns ajustes, os parâmetros e procedimentos de operação aplicados neste protocolo foram cuidadosamente determinados de forma a produzir resultados reprodutíveis e confiáveis. Assim, este protocolo pode ser usado para estudos comparativos do desempenho de diferentes configurações de células a combustível do tipo PEM, o que é fundamental para a realimentação dos projetos em desenvolvimento no IPEN. 


\section{SUGESTÕES PARA TRABALHOS FUTUROS}

A partir dos resultados obtidos com este trabalho, sugere-se:

a) $\mathrm{O}$ estudo comparativo da durabilidade e do desempenho de diferentes configurações de componentes de células a combustível do tipo PEM;

b) Estudos de durabilidade de DEFCs;

c) Ajustes de modelos estatísticos não lineares aos dados de testes de durabilidade de longa duração;

d) Testes de durabilidade acelerados no intuito de prever os resultados de testes de durabilidade de longa duração;

e) Testes de estresse acelerados para o estudo da durabilidade dos diferentes componentes de uma célula a combustível do tipo PEM. 


\section{Anexos}

Diagrama de blocos e rotinas elaboradas para implementação dos protocolos de Teste de

Durabilidade de Longa Duração (TDLD) para células a combustível do tipo PEM 
ANEXO A - DIAGRAMA DE BLOCOS DO PROTOCOLO IMPLEMENTADO

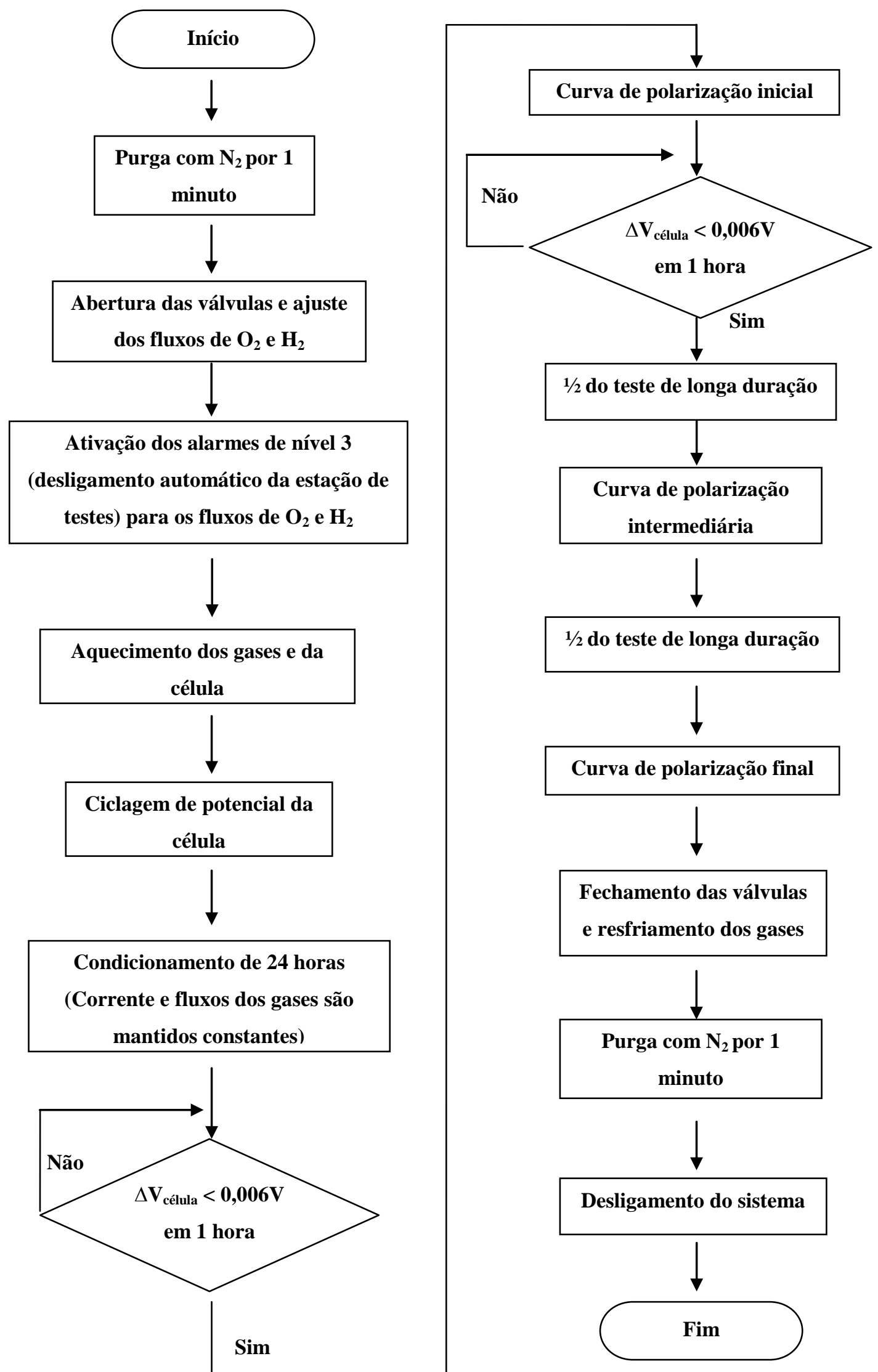




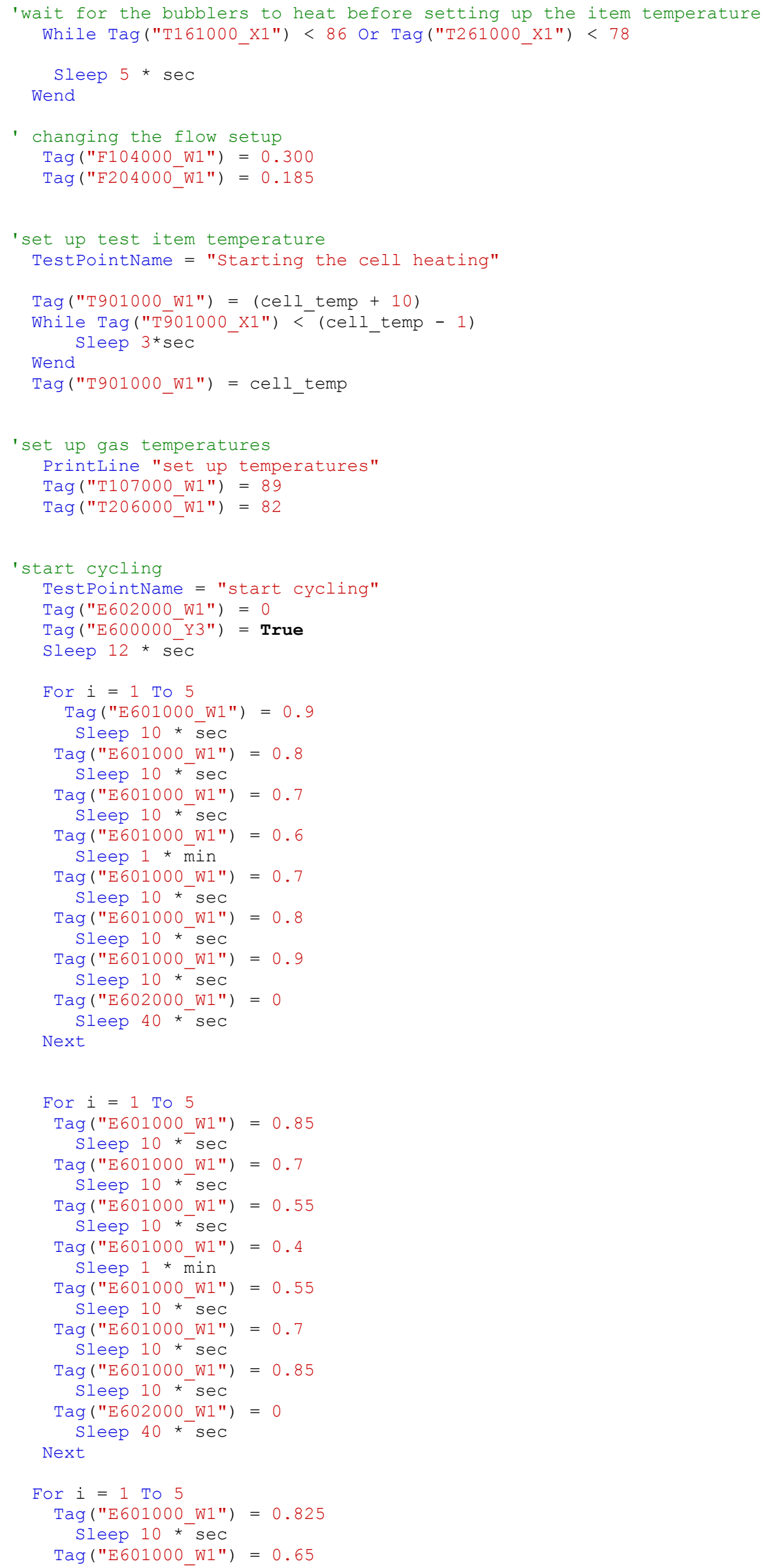




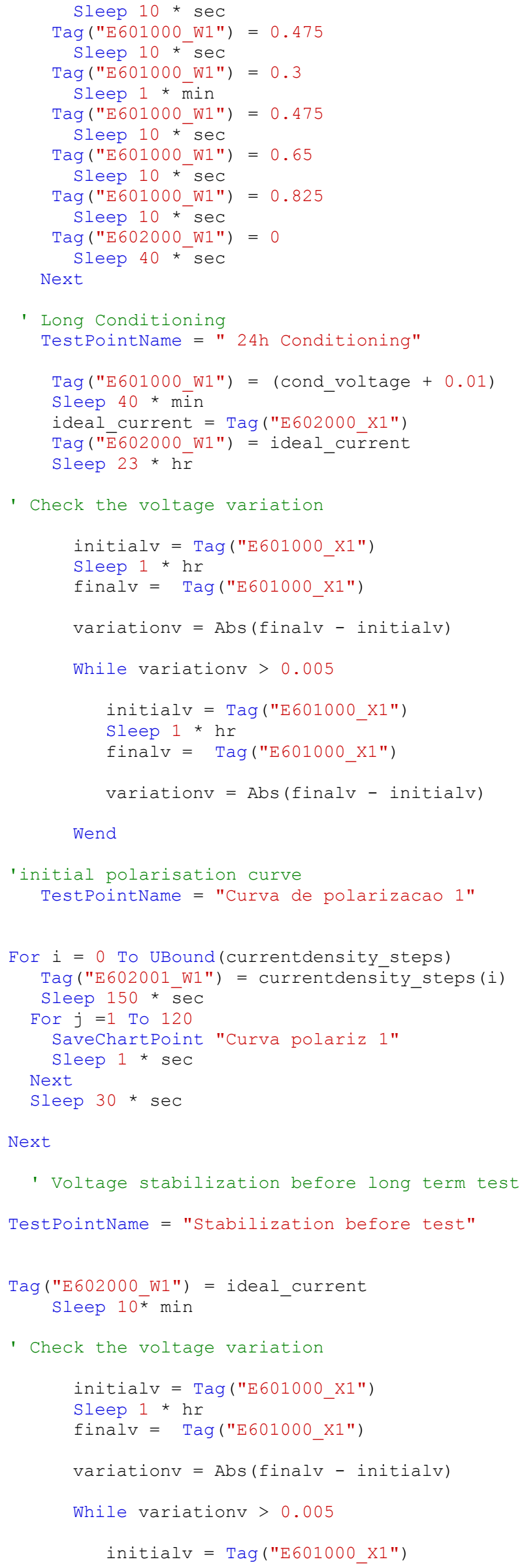




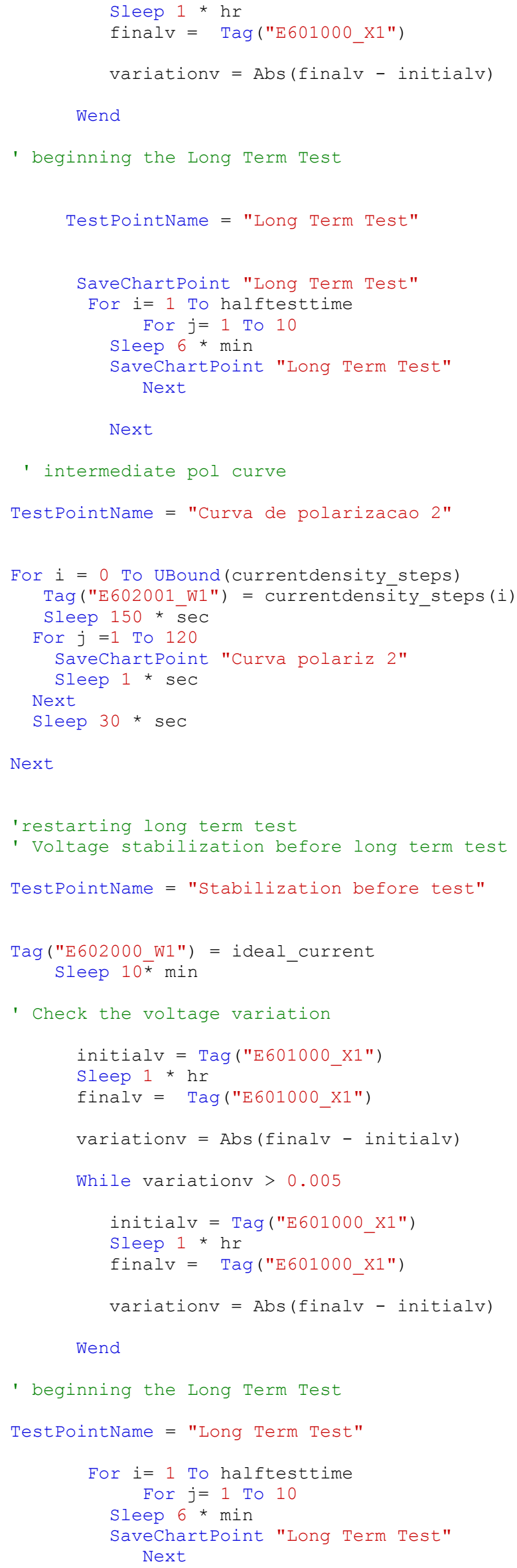


Next

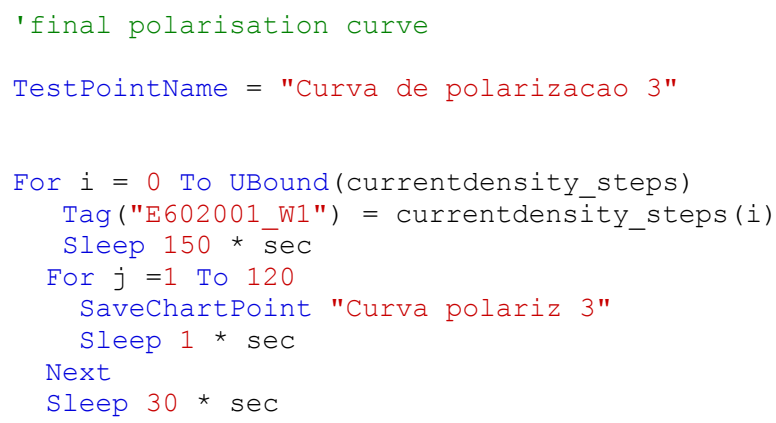




\section{ANEXO C- ROTINA UTILIZADA NO TESTE 3}

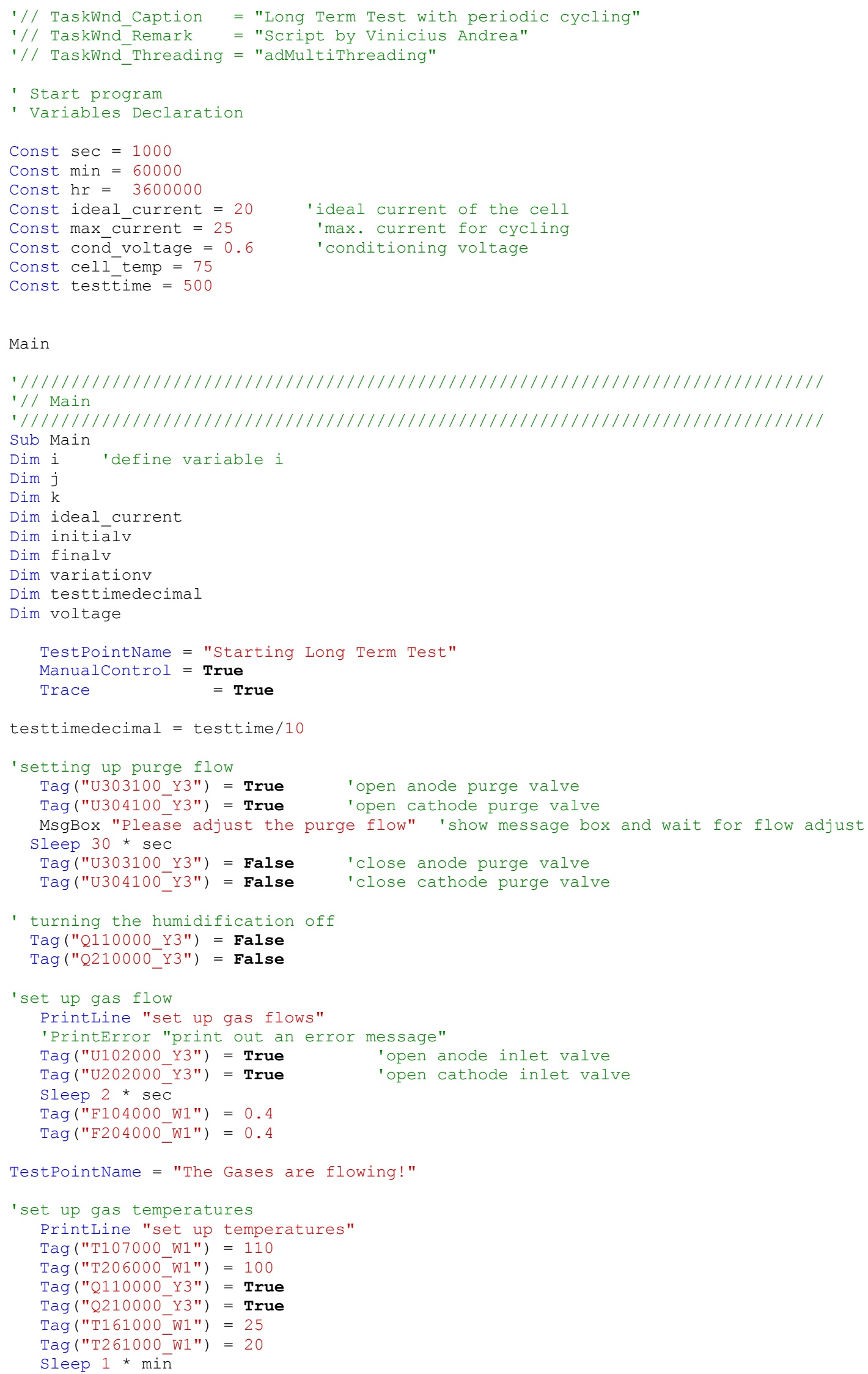




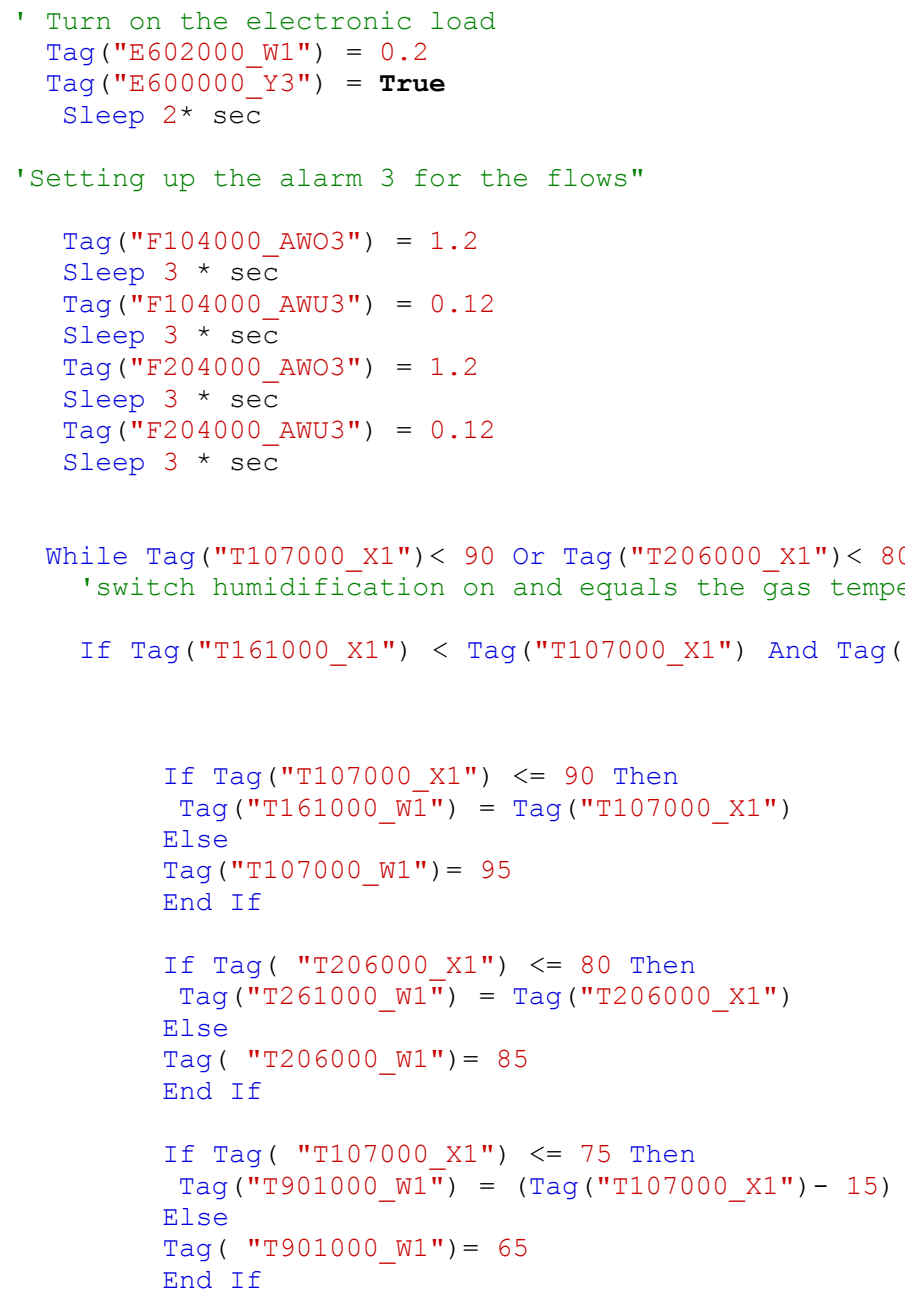

End If

TestPointName = "Waiting the gases and humidifiers to heat" Sleep 2 * sec

Wend

TestPointName = "Temperature of the gases reached!"

$\operatorname{Tag}\left(" \mathrm{E} 602000 \_W 1 "\right)=0.5$

'set up gas temperatures

PrintLine "set up temperatures"

Tag ("T107000 W1") = 100

Tag $\left(" T 206000^{-} W 1 "\right)=90$

Tag ("Q110000_Y3") = True

Tag ("Q210000_Y3") = True

$\operatorname{Tag}(" \mathrm{~T} 161000 \mathrm{W1} ")=90$

$\operatorname{Tag}\left(" \mathrm{~T} 261000^{-} \mathrm{W} 1 "\right)=80$

'wait for the bubblers to heat before setting up the item temperature While Tag("T161000_X1") < 88 Or Tag("T261000X1") < 78

Sleep 5 * sec

Wend

' changing the flow setup

Tag ("F104000 W1") $=0.220$

Tag ("F204000_W1") $=0.180$

'set up test item temperature 


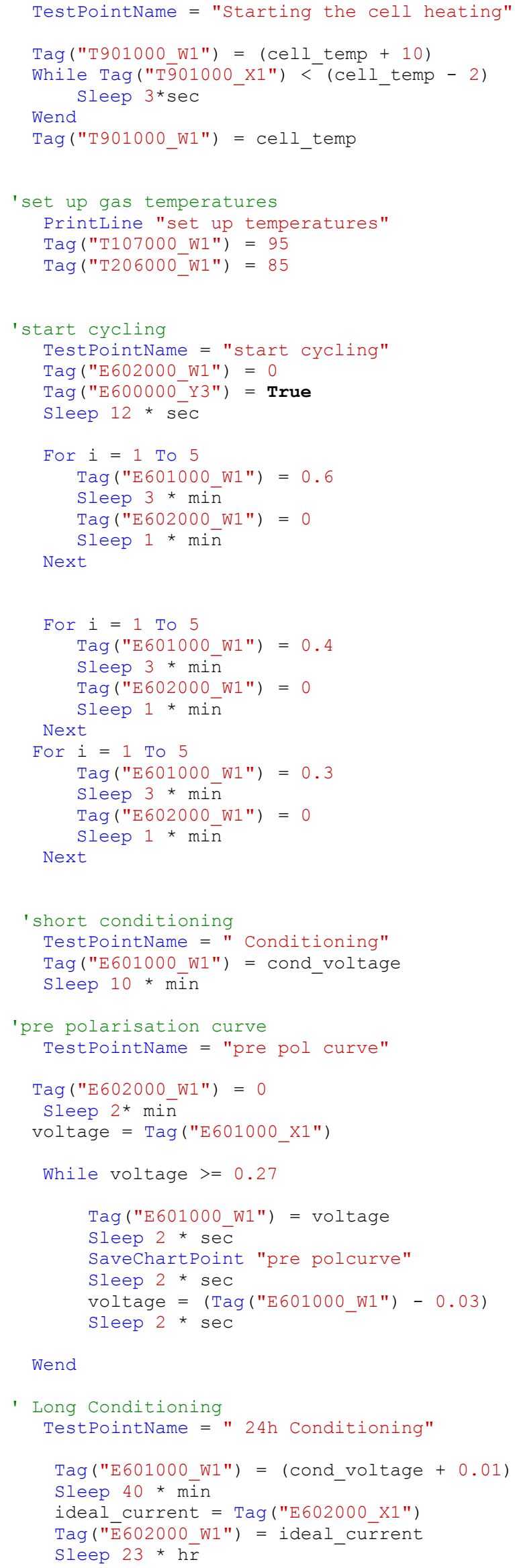


' Check the voltage variation

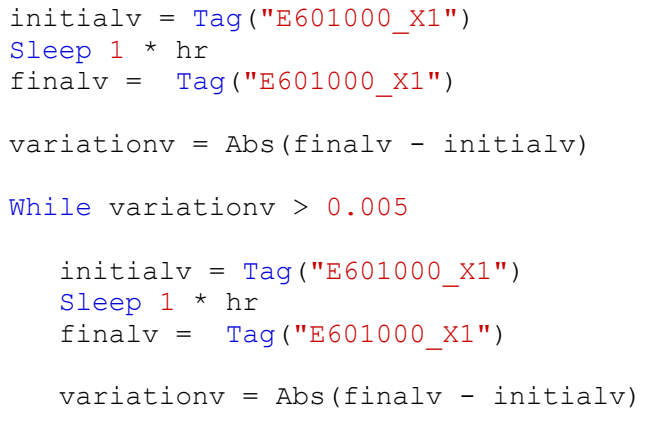

Wend

' Voltage stabilization before long term test

TestPointName = "Stabilization before test"

Tag ("E602000_W1") = ideal_current Sleep 10* min

' Check the voltage variation

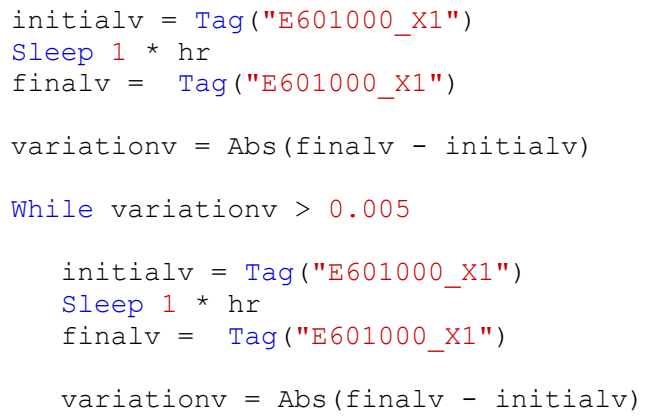


Sleep $6 * \min$

SaveChartPoint "Long Term Test" Next

Next

'start cycling for each 1/10 of the testtime TestPointName = "interpolated cycling"

Tag ("E602000_W1") = 0

Sleep 30 * sec

For $i=1$ To 3

$\operatorname{Tag}(" E 601000$ W1") $=0.7$

Sleep $1 * \min$

Tag ("E602000 W1") = 0

Sleep 30 * secc

Next

For $i=1$ To 3

$\operatorname{Tag}\left(" E 601000 \_W 1 "\right)=0.4$

Sleep $1 * \min$

$\operatorname{Tag}(" E 602000$ W1") = 0

Sleep 30 * secc

Next

For $i=1$ To 3

$\operatorname{Tag}(" \mathrm{E} 601000 \mathrm{~W} 1 ")=0.3$

Sleep 1 * min

$\operatorname{Tag}(" E 602000$ W1") = 0

Sleep 30 * sec

Next

Tag $(" E 602000 \mathrm{~W} 1 ")=0$

Sleep $3 * \min$

'Take a partial polarisation curve

TestPointName = "partial pol curve"

Tag ("E602000_W1") = 0

Sleep 2* $\min$

voltage = Tag ("E601000_X1")

While voltage $>=0.27$

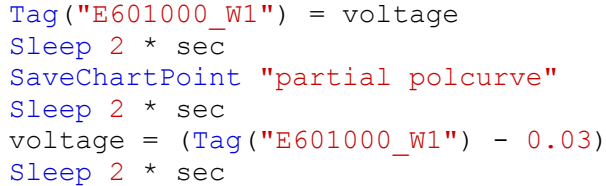

Wend

TestPointName = "Preparing to continue LTT"

Tag ("E602000 W1") = ideal current

' Check the voltage variation

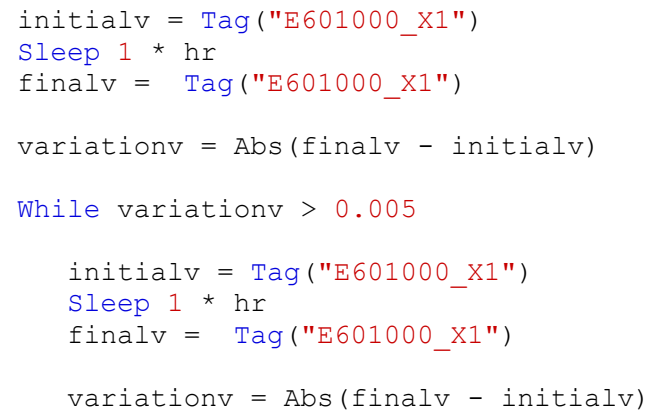

Wend 
Next

' Recycling before final pol curve

For $i=1$ To 5

Tag ("E601000 W1") $=0.4$

Sleep $3 * \min$

$\operatorname{Tag}(" E 602000 \mathrm{~W} 1 ")=0$

sleep $2 * \min$

Next

Tag ("E602000_W1") = 0

sleep 1* $\min$

'final polarisation curve

TestPointName = "Final pol curve"

Tag ("E602000_W1") = 0

Sleep 2* min

voltage $=$ Tag $\left(" \mathrm{E} 601000 \_\mathrm{X} 1 "\right)$

While voltage $>=0.27$

Tag ("E601000_W1") = voltage

Sleep 2 * sec

SaveChartPoint "final polcurve"

Sleep 2 * sec

voltage $=($ Tag $(" E 601000 \mathrm{WI} ")-0.03)$

Sleep 2 * sec

Wend

'switch off electronic load

Tag ("E600000 Y3") = False

Tag ("E602000_W1") = 0

'shutdown of the system

Tag("Q110000_Y3") = False ' turning down the humidification

Tag ("Q210000-Y3") = False

Tag("T161000_W1") = 0 ' turning down the humidification temperature

Tag $\left(" T 261000^{-} W 1 "\right)=0$

Sleep $10 *$ sec

Tag("T107000 W1") = 0 ' turning down the gas temperature

$\operatorname{Tag}\left(" T 206000^{-} W 1 "\right)=0$

Tag("T901000_W1") = 0 ' turning down the cell temperature

'Turning off the alarm 3 for the flows"

Tag ("F104000 AWU3") $=0.0$

sleep 3 * sec

Tag ("F104000_AWO3") = 0.0

Sleep 3 * sec

$\operatorname{Tag}\left(" F 204000 \_\right.$AWU3") $=0.0$

Sleep $3 *$ sec

Tag ("F204000 AWO3") $=0.0$

Sleep $3 *$ sec

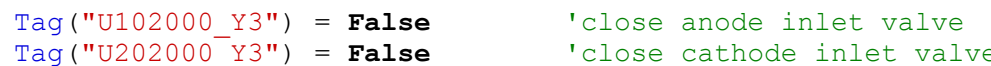

Tag $(" F 104000$ W1") = 0

Tag $(" F 204000$ W1") $=0$ 


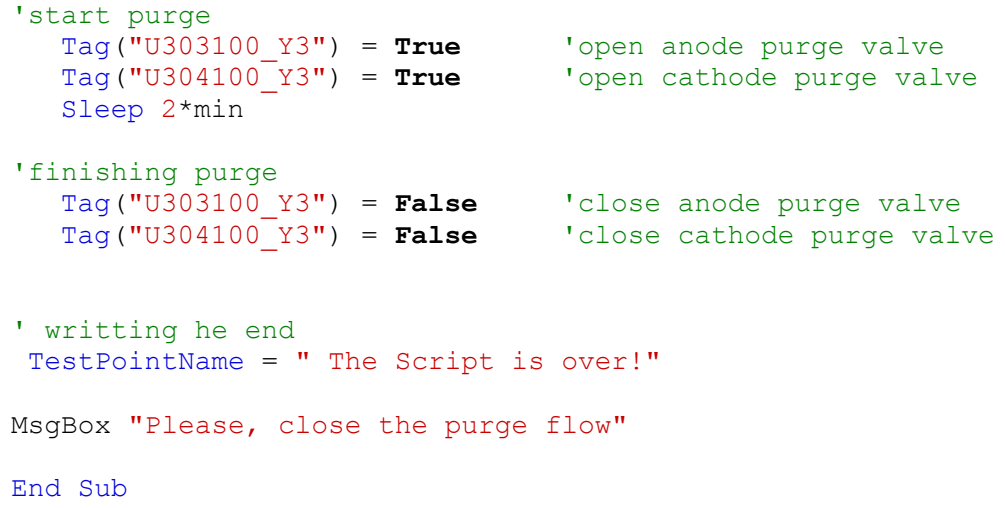




\section{ANEXO D - ROTINA UTILIZADA NO TESTE 4}

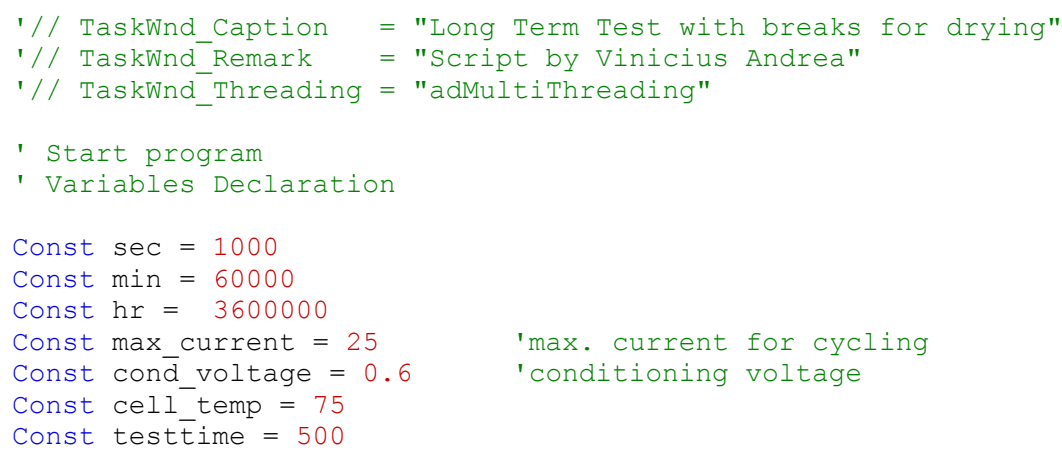



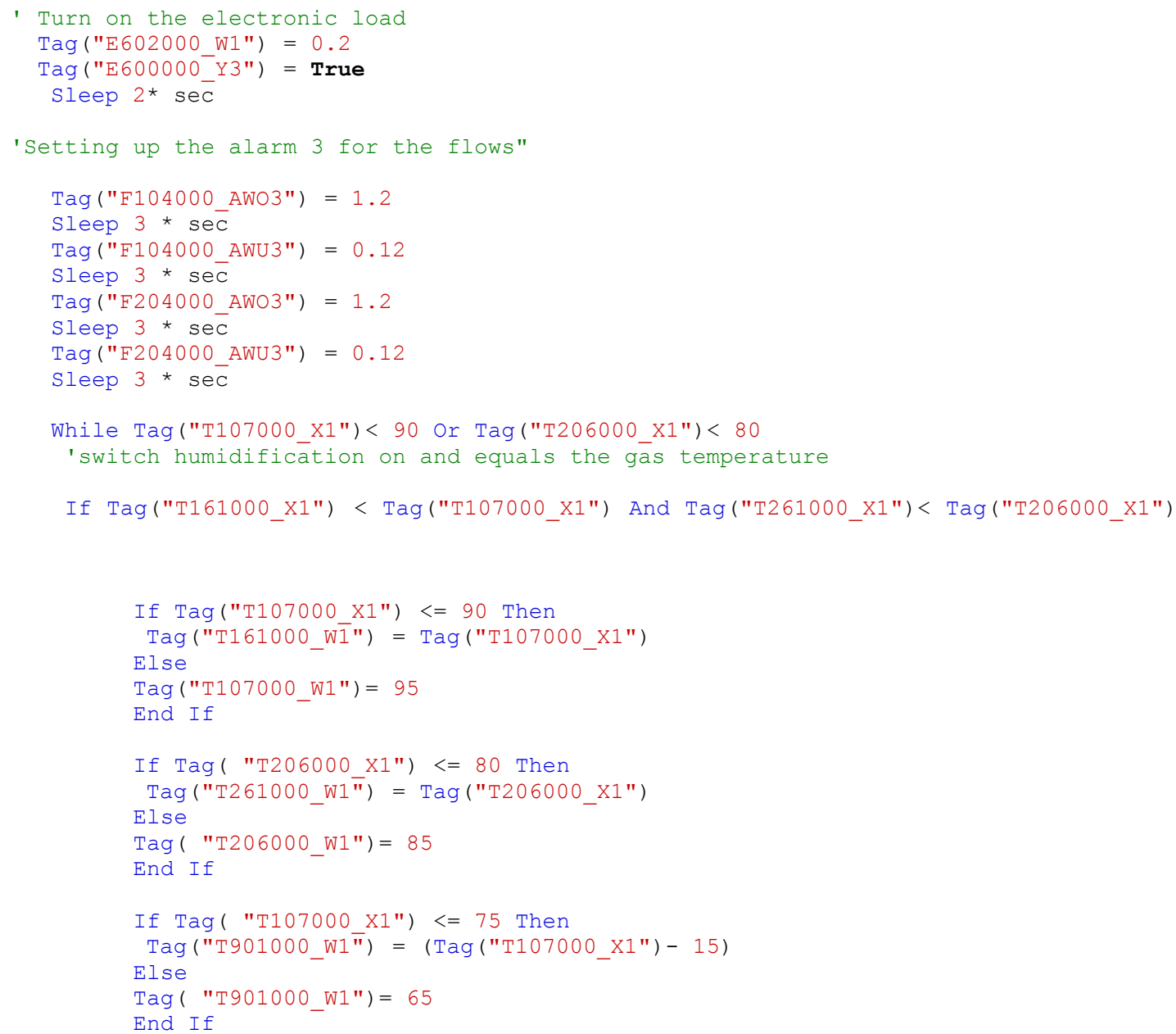

End If

TestPointName $=$ "Waiting the gases and humidifiers to heat" Sleep $2 *$ sec

Wend

TestPointName $=$ "Temperature of the gases reached!"

Tag $\left(" E 602000 \_\right.$W1") $=0.5$

'set up gas temperatures

PrintLine "set up temperatures"

Tag $(" T 107000$ W1") $=100$

Tag $\left(" T 206000^{-}\right.$W1" $)=90$

Tag $(" Q 110000$ Y3") = True

Tag $(" Q 210000$ Y3") = True

Tag $(" T 161000 \mathrm{~W} 1 ")=90$

$\operatorname{Tag}\left(" \mathrm{~T} 261000^{-} \mathrm{W} 1 "\right)=80$

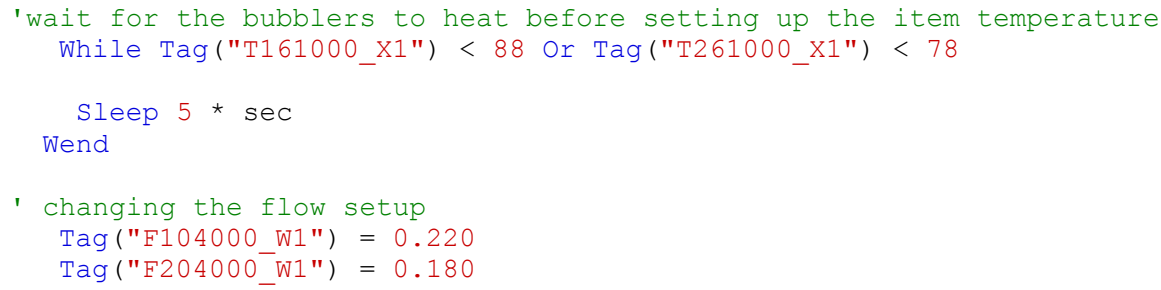




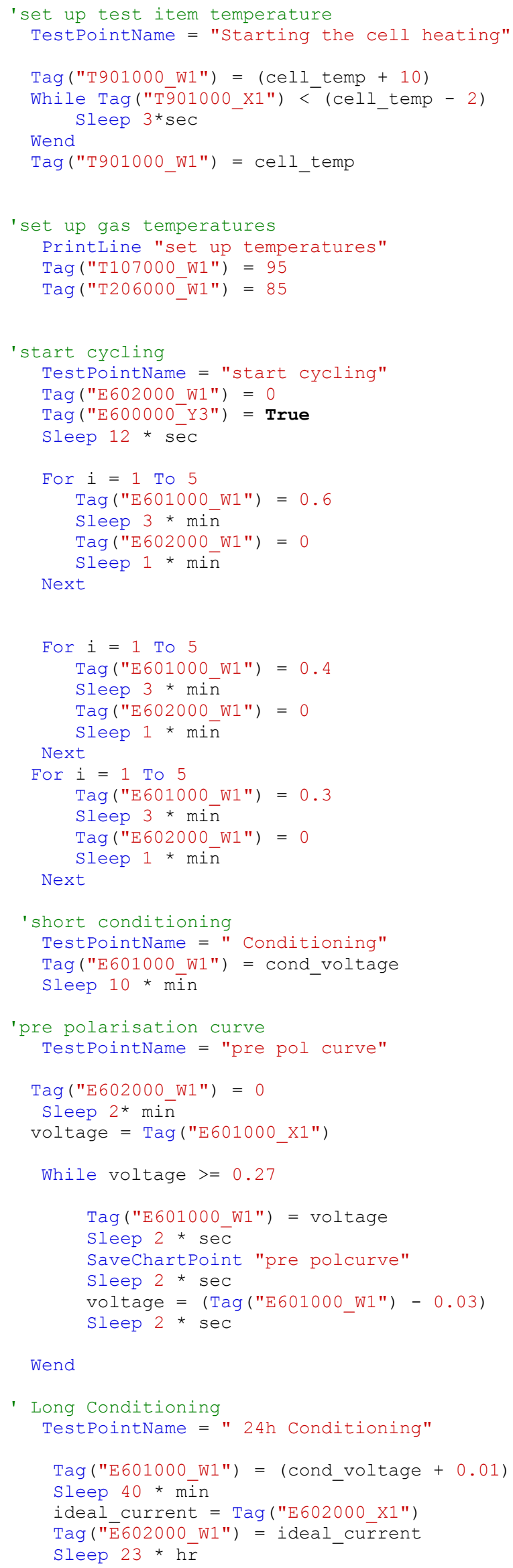


' Check the voltage variation

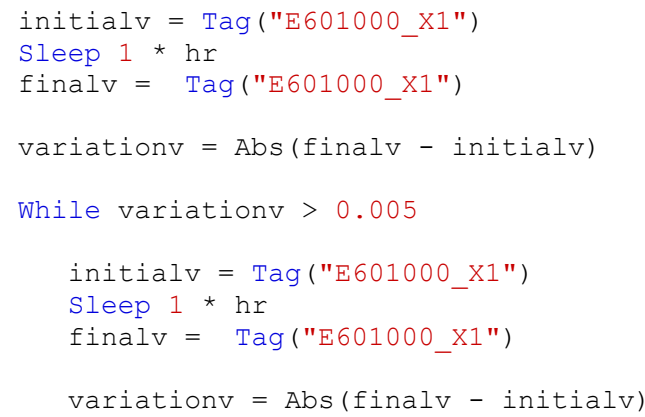




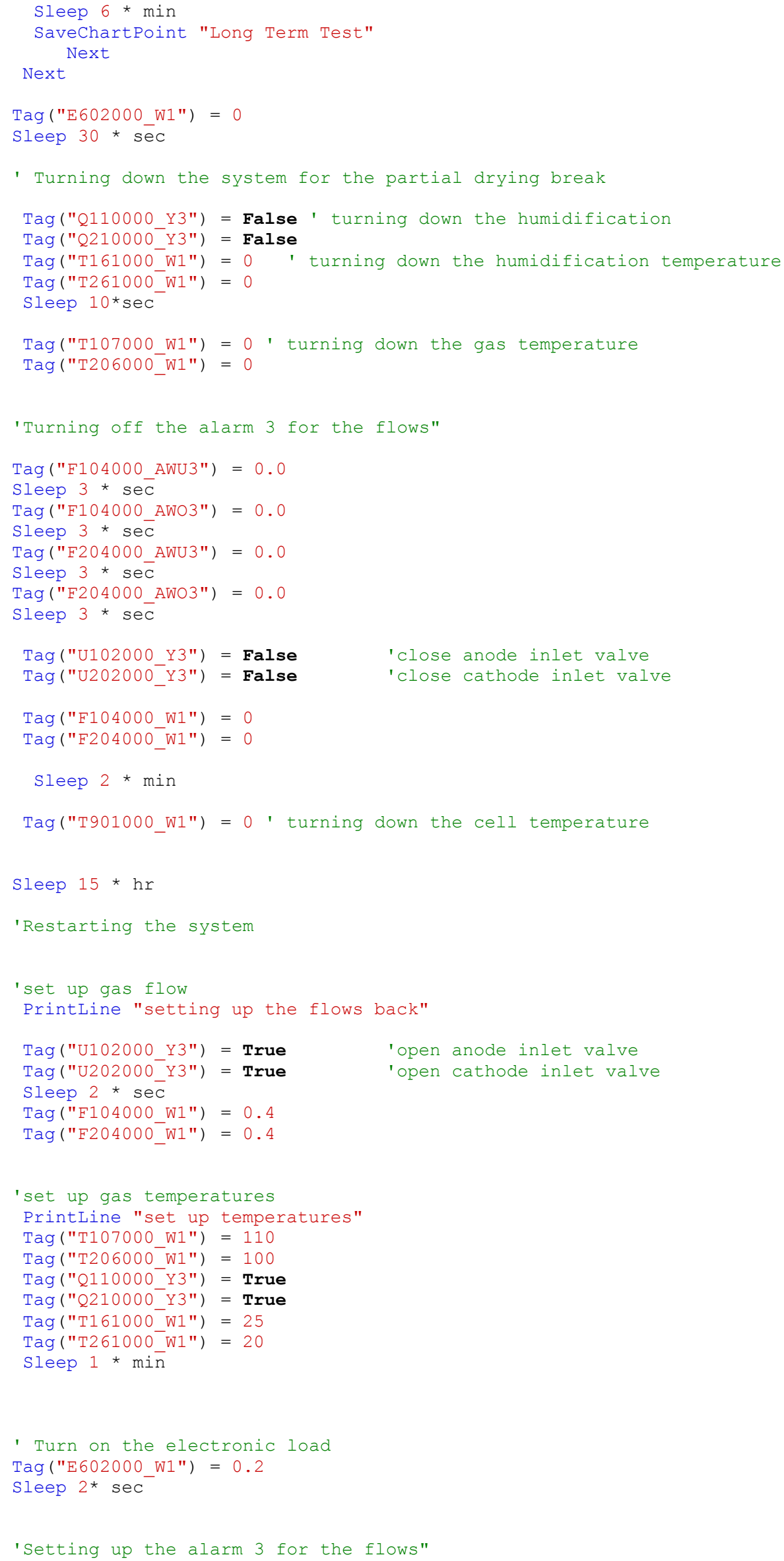




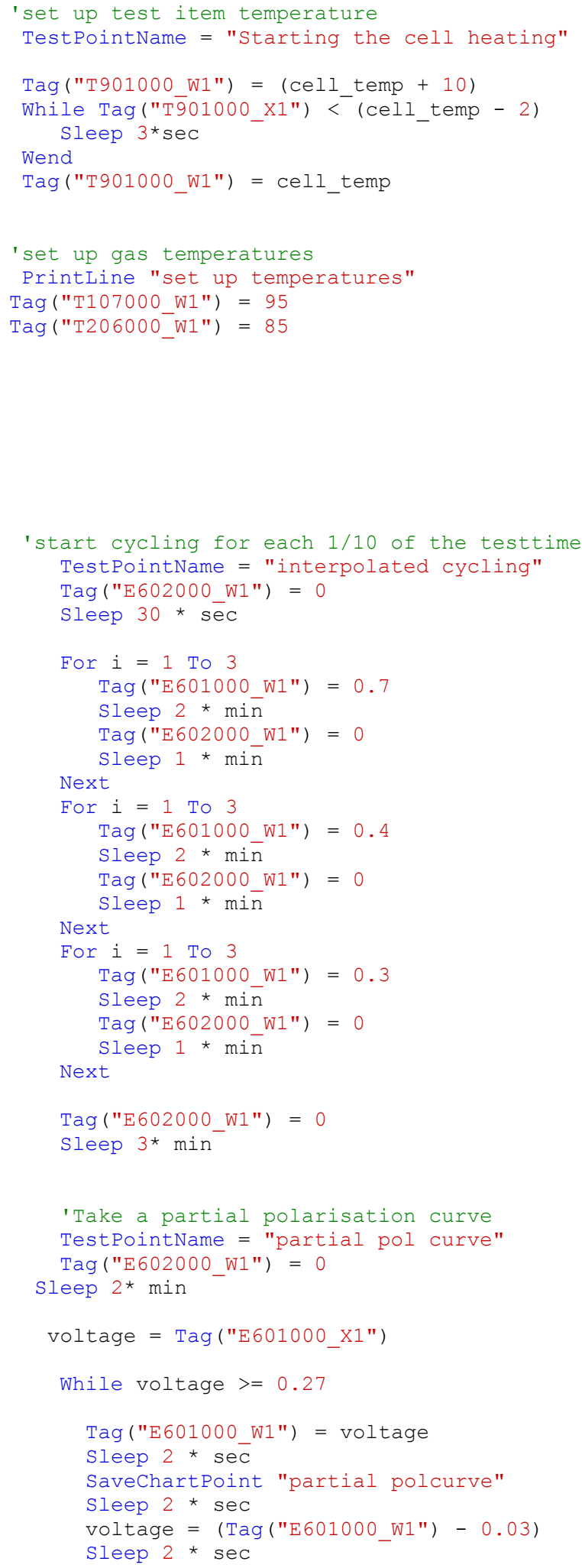




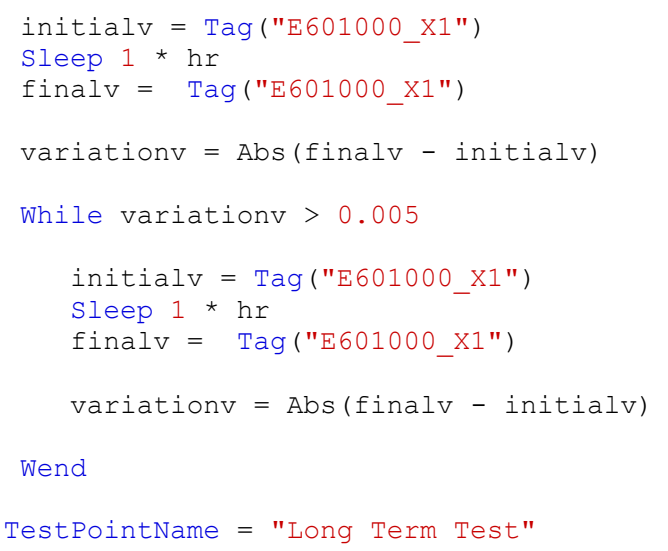

Next

' Recycling before final pol curve

For $i=1$ To 5

Tag ("E601000_W1") $=0.4$

Sleep $3 \star \min$

$\operatorname{Tag}(" E 602000$ W1") $=0$

Sleep 2 * min

Next

Tag ("E602000_W1") = 0

Sleep 1* min

'final polarisation curve

TestPointName = "Final pol curve"

$\operatorname{Tag}(" \mathrm{E} 602000 \mathrm{WI} ")=0$

Sleep 2* min

voltage $=$ Tag $\left(" \mathrm{E} 601000 \_\mathrm{X} 1 "\right)$

While voltage $>=0.27$

$\operatorname{Tag}(" \mathrm{E} 601000 \mathrm{W1} ")$ = voltage

Sleep 2 * sec

SavechartPoint "final polcurve"

Sleep $2 *$ sec

voltage $=\left(\operatorname{Tag}\left(" E 601000 \_W 1 "\right)-0.03\right)$

Sleep 2 * sec

Wend

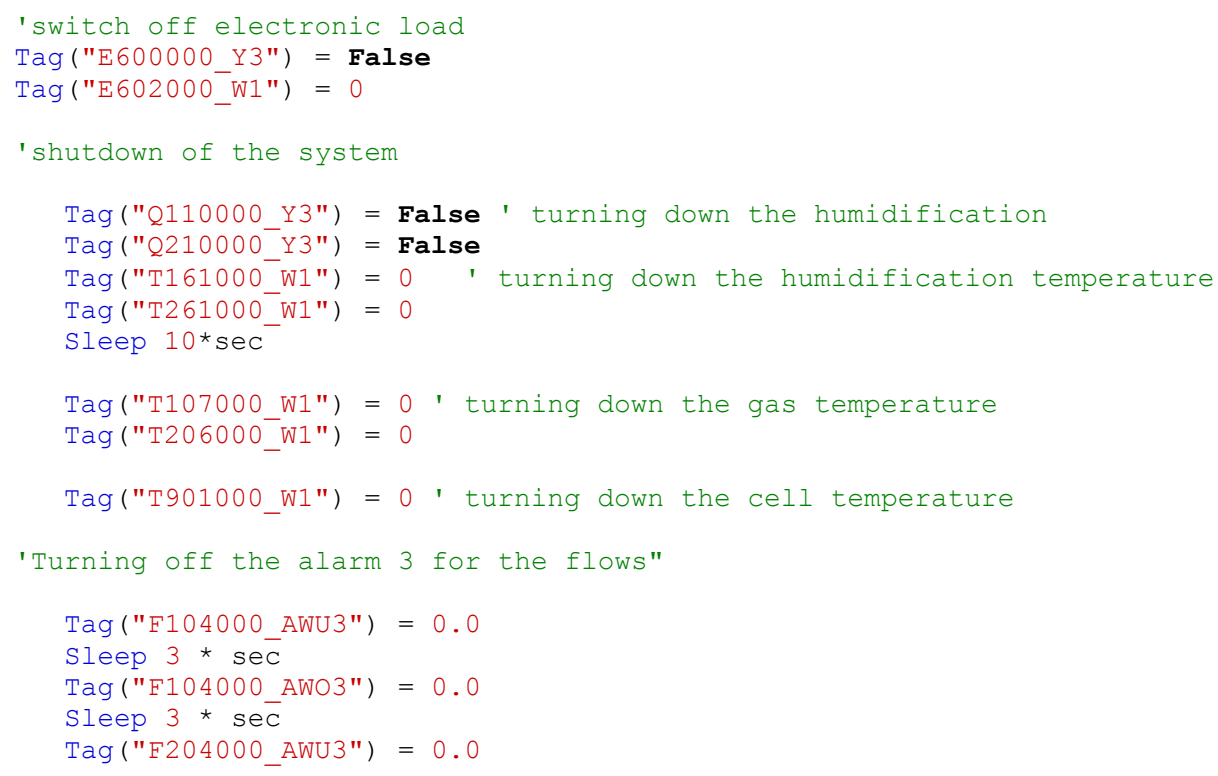




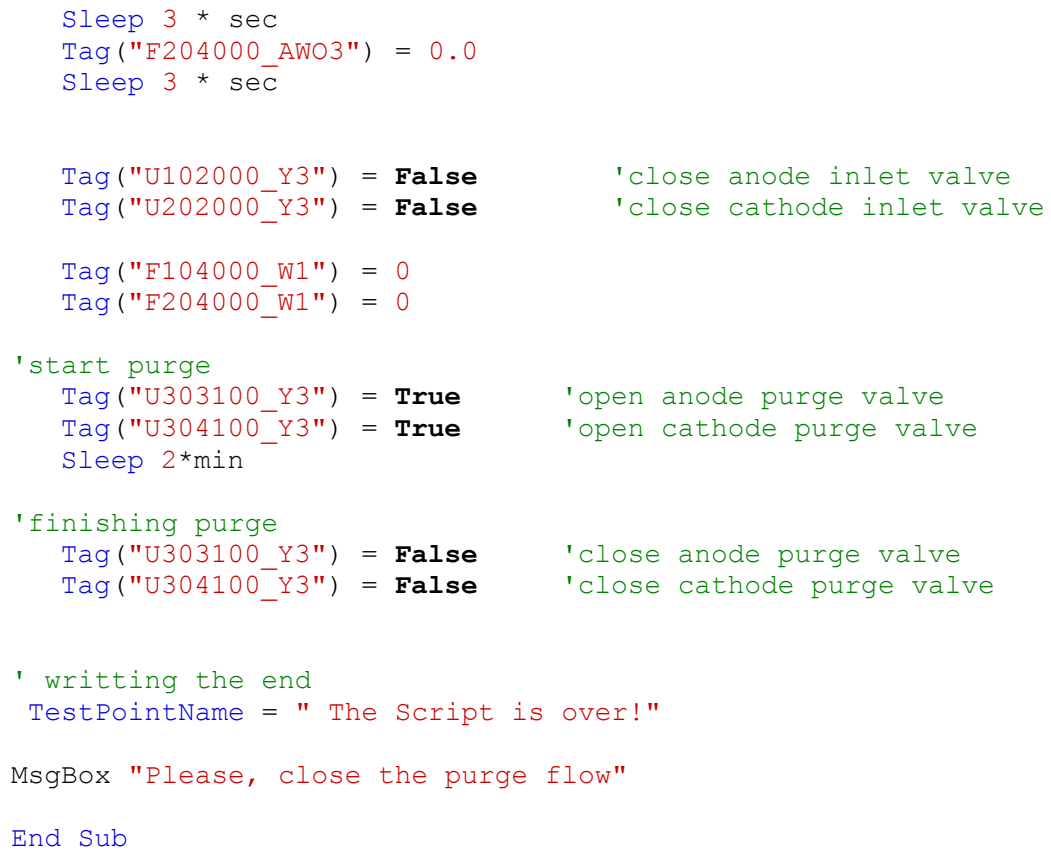




\section{REFERÊNCIAS BIBLIOGRÁFICAS}

[1] WILlianS, J. C. History of Energy. The Franklin Institute. Disponível em < http://www.fi.edu/learn/case-files/energy.html >. Acesso em: 14 de maio de 2013.

[2] COOK, E. F. Man, energy, society. San Francisco: W. H. Freeman and Company, 2011.

[3] WENDT, H.; GÖTZ, M.; LINARDI, M. Tecnologia de células a combustível, Química Nova, v.23, p. 538-546, 2000.

[4] LINARDI, M; Introdução à ciência e tecnologia de células a combustível. São Paulo:Editora Artliber, 2010.

[5] LINDEN, D. Handbook of Batteries and Fuel Cells. Nova Yorque: McGraw-Hill Book Company, 1984.

[6] WENDT, H.; LINARDI, M.; ARICÓ, E. Células a combustível de baixa potência para aplicações estacionárias. Química Nova, v. 25, p.470 - 476, 2002.

[7] CRISAFUlli, R. Preparação de Eletrocatalisadores PtSnCu/C e PtSn/C e Ativação por Processos de Dealloying para Aplicação na Oxidação Eletroquímica do Etanol. 2013. Tese (Doutorado) - Instituto de pesquisas energéticas e nucleares, São Paulo.

[8] GOTTESFELD, S.; ZAWODZINSKI, T.A. Advances in Electrochemical Science and Engineering. Weinhein, Germany. Wiley-VCH., 1997.

[9] BLADERGROEN, B.; SU, H.; PASUPATHI, S.; LINKOV, V. In: LINKOV, V. Electrolysis. [S.I.]: Intech, p. 45-60, 2012.

[10] U. S. DOE. Hydrogen, Fuel Cells \& Infrastructure Technologies Program MultiYear Research, Development and Demonstration Plan. Disponível em: < http://www1.eere.energy.gov/hydrogenandfuelcells/mypp.>. Acesso em 16 de maio de 2013. 
[11] YUAN, X.; LI, H; ZHANG, S.; MARTIN, J.; WANG, H. A review of polymer electrolyte membrane fuel cell durabilty test protocols. Journal of Power Sources, v. 196, p. 9107-9116, 2011.

[12] FERNANDES, C.V.; CUNHA, E.; BONIFACIO, R. et al. Desenvolvimento de tecnologia para confecção de eletrodos e conjuntos eletrodo-membrana-eletrodo (MEA) por impressão à tela para aplicação em módulos de potência de células PEMFC. Química Nova, p. 1-5, 2012.

[13] ANDRADE, A. B. Desenvolvimento de conjuntos eletrodo-membrana-eletrodo para células a combustivel a membrana trocadora de prótons (PEMFC) por impressão à tela. 2008. Dissertação (Mestrado) - Instituto de pesquisas energéticas e nucleares, São Paulo, p. 43-82.

[14] ANDRADE, A.B; BEJORANO, M. L. M; CUNHA, E,F; ROBALINHO, E; LINARDI, M;. Fabrication of High Precision PEMFC Membrane Electrode Assemblies by Sieve Printing Method. Journal of Fuel Cell Science and Technology, v. 6, 2009.

[15] BONIFACIO, R. Desenvolvimento de processo de produção de conjuntos eletrodomembrana-eletrodo para células a combustível baseadas no uso de membrana polimérica condutora de prótons (PEMFC) por impressão a tela. 2010. Dissertação (Mestrado) - Instituto de pesquisas energéticas e nucleares, São Paulo.

[16] BORUP, R; MEYERS, J.; PIVOVAR, B.; et al. Scientifics aspects of polymer electrolyte fuel cell durability and degradation. Chemical Reviews. v. 107, p.3904-3951, 2007.

[17] MALKOW, T.; SATURNIO, A.;PILENGA, A.; DE MARCO, G. HONSELAAR, M.; TSOTRIDIS, G. Assessment of PEFC performance by applying harmonized testing procedure. International Journal of Energy research, v. 35, p. 1075 - 1089, 2011.

[18] KNIGHTS, S.D.; COLBOW, K.M.; ST-PIERRE, J. WILKINSON, D.P. Aging mechanisms and lifetime of PEFC and DMFC. Journal of Power Sources, v. 127, p. 127$134,2004$.

[19] BRUIJN, F.A. de; DAM, V.A.T.; JANSSEN, G.J.M. Review: Durability and degradation issues of PEM fuel cell components. Fuel Cells, v. 8, n. 1, p. 3-22, 2008. 
[20] WILKINSON, D.P.; ST-PIERRE, J. IN: VIELSTICH, W.; GASTEIGER, H.A.; LAMM, A. Handbook of Fuel Cells: Fundamentals, Technology and Applications. vol. 3, John Wiley \& Sons Ltd., p. 611-626, 2003.

[21] SEO, D.; LEE, J.; PARK, S.; RHEE, J.; CHOI, S. W.; SHUL, Y. Investigation of MEA degradation in PEM fuel cell by on/off cyclic operation under different humid conditions. International Journal of Hydrogen Energy. v. 36, p. 1828 - 1836, 2010.

[22] WU, J.; YUAN, X.Z.; MARTIN, J.J.; WANG, H.; ZHANG, J.; SHEN, J.; WU, S.; MERIDA, W. A review of PEM fuel cell durability: degradation mechanisms and mitigation strategies. Journal of Power Sources, v. 184, p. 104-119, 2008.

[23] VENGATESAN, S.; FOWLER, W. M.; YUAN, X.; WANG, H. Diagnosis of MEA degradation under accelerated relative humidity cycling. Journal of Power Sources, v. 196, p. 5045-5052, 2011.

[24] SCHMITTINGER, W.; VAHIDI, A. A review of the main parameters influencing long-term performance and durability of PEM fuel cells. Journal of Power Sources, v. 180, p. 1-14, 2008.

[25] ZHANG, J.; TANG, Y.; SONG, C.; XIA, Z.; LI,H.; WANG, H.; ZHANG, J. PEM fuel cell relative humidity $(\mathrm{RH})$ and its effect on performance at high temperatures. Electrochimica Acta, v. 53, p. 5315-5321, 2008.

[26] ZHANG, S.; YUAN, X.; WANG, H.; MÉRIDA, W.; ZHU, H.; SHEN, J.; WU, S.; ZHANG, J. A review of accelerated stress tests of MEA durability in PEM fuel cells. International Journal of Hydrogen Energy, v. 34, p. 388 - 404, 2008.

[27] LIU, D.; CASE, S. Durability study of proton exchange membrane fuel cells under dynamic testing conditions with cyclic current profile. Journal of Power Sources, v. 162, p. 521-531, 2006.

[28] LIN, R.; LI, B.; HOU, Y.P.; MA, J.M. Investigation of dynamic driving cycle effect on performance degradation and micro-structure change of PEM fuel cell. International Journal of Hydrogen Energy, v. 34, p. 2369 - 2376, 2009. 
[29] MARRONY, M.; BARRERA, R.; QUENET, S.; GINOCCHIO, S.; MONTELATICI, L.; ASLANIDES, A. Durability study and lifetime prediction of baseline proton exchange membrane fuel cell under severe operating conditions. Journal of Power Sources, v. 182, p. 469-475, 2008.

[30] LIANG, D.; DOU, M.; HOU, M.; SHEN, Q.; SHAO, Z.; YI, B. Behavior of a unit proton exchange membrane fuel cell in a stack under fuel starvation. Journal of Power Sources, v. 196, p. 5595-5598, 2011.

[31] FCTESTNET. Testing the voltage-power as function of time at fixed current density (long term durability steady test for a PEFC single cell). Test Module PEFC SC 5-6. October, 2006. <Disponível em http://fctesqa.jrc.ec.europa.eu:80/.> Acesso em: 23 maio de 2013.

[32] FCTESTNET. Testing the voltage-power as function of the current density (polarization curve for a PEFC single cell). Test Module PEFC SC 5-2. October, 2006. Disponível em http://fctesqa.jrc.ec.europa.eu:80/. Acesso em: 23 maio de 2013.

[33] BUSSAB, W.O; MORETTIN, P.A. Estatística Básica. 6.ed. São Paulo: Saraiva, 2010.

[34] HOFFMANN, R.; VIEIRA, S. Análise de Regressão: uma introdução à econometria. São Paulo: HUCITEC, Ed. da Universidade de São Paulo, 1977.

[35] ORIGINPRO 8 PRO, version 8.074. Northampton, USA: OriginLab Corporation, 1991-2007. 